\title{
Recent Applications of Electrocoagulation in Treatment of Water and Wastewater-A Review
}

\author{
Ville Kuokkanen $^{1 *}$, Toivo Kuokkanen ${ }^{1}$, Jaakko Rämö ${ }^{2}$, Ulla Lassi ${ }^{1,3}$ \\ ${ }^{1}$ Department of Chemistry, University of Oulu, Oulu, Finland \\ ${ }^{2}$ Thule Institute, University of Oulu, Oulu, Finland \\ ${ }^{3}$ Kokkola University Consortium Chydenius, Kokkola, Finland \\ Email: *ville.kuokkanen@oulu.fi
}

Received February 5, 2013; revised March 6, 2013; accepted March 15, 2013

Copyright (C) 2013 Ville Kuokkanen et al. This is an open access article distributed under the Creative Commons Attribution License, which permits unrestricted use, distribution, and reproduction in any medium, provided the original work is properly cited.

\begin{abstract}
During the last two decades, and particularly during the last few years, the environmental sector has shown a largely growing interest in the treatment of different types of water and wastewater by electrocoagulation (EC). The aim of this work was to review studies, conducted mainly during 2008-2011, on the wide and versatile range of feasible EC applications employed in the purification of different types of water and wastewater. The EC applications discussed here were divided into 7 following categories: tannery, textile and colored wastewater; pulp and paper industry wastewater; oily wastewater; food industry wastewater; other types of industrial wastewater; surface water as well as model water and wastewater containing heavy metals, nutrients, cyanide and other elements and ions. In addition, this paper presents an overview of the optimum process conditions (treatment times, current densities, and initial $\mathrm{pH}$ ) and removal efficiencies (mostly high) achieved for the EC applications discussed. In the vast majority of the studies discussed in this review, the aforementioned values were found to be in the range of 5 - 60 min (typically less than $30 \mathrm{~min}$ ), $10-150$ $\mathrm{A} / \mathrm{m}^{2}$ and near neutral $\mathrm{pH}$, respectively. Both operating costs and electrical energy consumption values were found to vary greatly depending on the type of solution being treated, being between $0.0047-6.74 € / \mathrm{m}^{3}$ and $0.002-58.0$ $\mathrm{kWh} / \mathrm{m}^{3}$, but in general they were rather low (typically around $0.1-1.0 € / \mathrm{m}^{3}$ and $0.4-4.0 \mathrm{kWh} / \mathrm{m}^{3}$ ).
\end{abstract}

Keywords: Electrochemistry; Electrocoagulation (EC); Water Treatment; Wastewater Purification; Technoeconomic Evaluation

\section{Introduction}

Electrocoagulation (EC) is an emerging technology that combines the functions and advantages of conventional coagulation, flotation, and electrochemistry in water and wastewater treatment. Each of these fundamental technologies has been widely studied separately. However, a quantitative appreciation of the mechanism of interaction between these technologies employed in an electrocoagulation system is absent [1].

$\mathrm{EC}$ has been known for over a century. Aluminium/ iron-based electrocoagulation was patented in the US already in 1909. EC was studied extensively in the latter half of the 20th century in both the US and the Soviet Union (former USSR), but at that time it was not found to be widely feasible for water treatment. This was mainly due to the then high electricity and investment costs [2].

\footnotetext{
"Corresponding author.
}

Meanwhile, the demand for quality drinking water quality is increasing globally and environmental regulations regarding wastewater discharge are becoming increasingly stringent. Therefore, it has become necessary to develop more effective treatment methods for water purification and/or enhance the operation of current methods. This and eco-friendliness have led to increasing global interest in electrocoagulation as a research subject. Over the course of the last few decades, literature in the environmental sector has indeed shown a growing interest towards the treatment of different types of wastewater by EC. Particularly during the last few years, the amount of published literature on EC applications seems to have increased substantially.

Practical review papers on EC applications have been largely absent so far. To the best of our knowledge, only a few authors, e.g. $[3,4]$ have addressed the subject recently, in addition to older reviews, (namely $[1,2,5]$ ), even though a significant number of studies on EC have 
been reported in the literature since then. Therefore, there is a need for an update on recent applications of EC. The aim of this work was to accomplish this, and based on the literature, to present an overview of practical optimum treatment times, current densities, electricity consumption, and operating costs in a wide and versatile range of feasible applications of EC in water and wastewater treatment, studied mainly during the years 20082011.

\section{Background}

\subsection{Principles of Electrocoagulation}

Electrolysis is a process in which oxidation and reduction reactions take place when electric current is applied to an electrolytic solution. Electrocoagulation is based on dissolution of the electrode material used as an anode. This so-called "sacrificial anode" produces metal ions which act as coagulant agents in the aqueous solution in situ [1]. At its simplest, an electrocoagulation system consists of an anode and a cathode made of metal plates, both submerged in the aqueous solution being treated [3]. The electrodes are usually made of aluminum, iron, or stainless steel (SS), because these metals are cheap, readily available, proven effective, and non-toxic. Thus they have been adopted as the main electrode materials used in EC systems [6,7]. The configurations of EC systems vary. An EC system may contain either one or multiple anode-cathode pairs and may be connected in either a monopolar or a bipolar mode [3]. During EC, the following main reactions take place at the electrodes. Anodic reactions [2]:

$$
\begin{gathered}
\mathrm{Al}(\mathrm{s}) \rightarrow \mathrm{Al}^{3+}+3 \mathrm{e}^{-} \quad E^{0}=+1.66 \mathrm{~V} \\
\mathrm{Fe}(\mathrm{s}) \rightarrow \mathrm{Fe}^{2+}+2 \mathrm{e}^{-} \quad E^{0}=+0.44 \mathrm{~V} \\
2 \mathrm{H}_{2} \mathrm{O}(\mathrm{l}) \rightarrow \mathrm{O}_{2}(\mathrm{~g})+4 \mathrm{H}^{+}+4 \mathrm{e}^{-} \quad E^{0}=-1.23 \mathrm{~V}
\end{gathered}
$$

Ferrous iron may be oxidized to $\mathrm{Fe}^{3+}$ by atmospheric oxygen or anode oxidation, and may be considered as [8]:

$$
\begin{gathered}
\mathrm{Fe}^{2+} \rightarrow \mathrm{Fe}^{3+}+\mathrm{e}^{-} \quad E^{0}=-0.77 \mathrm{~V} \\
2 \mathrm{Fe}^{2+}+\frac{1}{2} \mathrm{O}_{2}(\mathrm{~g})+\mathrm{H}_{2} \mathrm{O}(\mathrm{l}) \rightarrow 2 \mathrm{Fe}^{3+}+2 \mathrm{OH}^{-} \\
E_{0}=-0.37 \mathrm{~V}
\end{gathered}
$$

Cathodic reactions [2]:

$$
2 \mathrm{H}_{2} \mathrm{O}+2 \mathrm{e}^{-} \rightarrow \mathrm{H}_{2}(\mathrm{~g})+2 \mathrm{OH}^{-} \quad E^{0}=-0.83 \mathrm{~V}
$$

Additionally, when chloride is present and the anode potential is sufficiently high, the following reactions may take place in the EC cell [9]:

$$
2 \mathrm{Cl}^{-} \rightarrow \mathrm{Cl}_{2}+2 \mathrm{e}^{-} \quad E^{0}=-1.36 \mathrm{~V}
$$

$$
\begin{aligned}
& \mathrm{Cl}_{2}+\mathrm{H}_{2} \mathrm{O} \rightarrow \mathrm{HClO}+\mathrm{H}^{+} \mathrm{Cl}^{-} \quad E^{0}=-0.93 \mathrm{~V} \\
& \mathrm{HClO} \rightarrow \mathrm{H}^{+}+\mathrm{OCl}^{-}
\end{aligned}
$$

The formation of active chlorine species $\left(\mathrm{Cl}_{2}, \mathrm{HClO}\right.$, $\mathrm{OCl}^{-}$) enhances the performance of the EC reactor through oxidation reactions. The dissolution of the anode metal is based on Faraday's law:

$$
m_{\text {metal }}=\frac{I \times t_{s} \times M}{Z \times F}
$$

where $I$ is the applied current (A), $t_{s}$ is the treatment time (s), $\mathrm{M}$ is the molar mass of the electrode material $\left(M_{\mathrm{Al}}=\right.$ $\left.26.982 \mathrm{~g} / \mathrm{mol}, M_{\mathrm{Fe}}=55.845 \mathrm{~g} / \mathrm{mol}\right), z$ is the valency of ions of the electrode material $\left(z_{\mathrm{Al}}=3, z_{\mathrm{Fe}}=2\right)$, and $F$ is Faraday's constant $(96485 \mathrm{C} / \mathrm{mol})$.

It has been found that the theoretical amount of anodic dissolution is exceeded in real EC applications. This phenomenon is referred to as superfaradaic efficiency, and the experimental values of anode metal dissolution have varied between $105 \%$ and $190 \%$ of the theoretically expected value [10-15]. This phenomenon is thought to be attributed to pitting corrosion, especially in the presence of chlorine ions [2].

Electrochemically generated metal cations will react spontaneously, forming various monomeric species such as $\mathrm{Al}(\mathrm{OH})^{2+}, \mathrm{Al}(\mathrm{OH})^{2+}, \mathrm{Al}_{2}(\mathrm{OH})_{2}^{4+}$, and $\mathrm{Al}(\mathrm{OH})^{4-}$ and polymeric species such as $\mathrm{Al}_{6}(\mathrm{OH})_{15}^{3+}, \mathrm{Al}_{7}(\mathrm{OH})_{17}^{4+}$, $\mathrm{Al}_{8}(\mathrm{OH})_{20}^{4+}, \mathrm{Al}_{13} \mathrm{O}_{4}(\mathrm{OH})_{24}^{4+}$, and $\mathrm{Al}_{13}(\mathrm{OH})_{34}^{5+}$, which finally transform into $\mathrm{Al}(\mathrm{OH})_{3}$ according to complex precipitation kinetics [16]. Ferric ions generated electrochemically may form monomeric ions, ferric hydroxo complexes with $\mathrm{OH}^{-}$ions, and polymeric species. These species/ions are: $\mathrm{FeOH}^{2+}, \mathrm{Fe}(\mathrm{OH})_{2}^{+}, \mathrm{Fe}_{2}(\mathrm{OH})_{2}^{4+}$, $\mathrm{Fe}(\mathrm{OH})_{4}^{-}, \mathrm{Fe}\left(\mathrm{H}_{2} \mathrm{O}\right)_{5} \mathrm{OH}^{2+}, \mathrm{Fe}\left(\mathrm{H}_{2} \mathrm{O}\right)_{4}(\mathrm{OH})_{2}^{+}$, $\mathrm{Fe}\left(\mathrm{H}_{2} \mathrm{O}\right)_{8}(\mathrm{OH})_{2}^{4+}$, and $\mathrm{Fe}_{2}\left(\mathrm{H}_{2} \mathrm{O}\right)_{6}(\mathrm{OH})_{4}^{2+}$, which further react to form $\mathrm{Fe}(\mathrm{OH})_{3}$ [17-19]. The formation of these complexes depends strongly on the $\mathrm{pH}$ of the solution. Above $\mathrm{pH} 9, \mathrm{Al}(\mathrm{OH})^{4-}$ and $\mathrm{Fe}(\mathrm{OH})^{4-}$ are the dominant species [20].

Aluminum and iron hydrolysis products then destabilize pollutants present in the solution, allowing agglomeration and further separation from the solution by settling or flotation. Destabilization is achieved mainly by means of two distinct mechanisms, i.e. 1) charge neutralization of negatively charged colloids by cationic hydrolysis products; and 2) "sweep flocculation", where impurities are trapped and removed in the amorphous hydroxide precipitate produced. Several factors such as $\mathrm{pH}$ and coagulant dosage have an impact on the relative importance of charge neutralization and sweep flocculation. Microbubbles $\left(\mathrm{H}_{2}\right.$ and $\left.\mathrm{O}_{2}\right)$ released at the electrode 
surfaces bring about electroflotation by adhering to agglomerates and carrying them to the water surface [21].

The most important factors influencing the efficiency of the EC process are the electrode materials used, applied current density, treatment time, and solution chemistry, including initial $\mathrm{pH}$ and the chemical composition of the aqueous solution being removed. The solution temperature, type of salt used to raise conductivity, presence of chloride, electrode gap, passivation of the anode, and water flow rate also have an impact on the removal efficiency and economic durability of a given EC application.

The advantages of EC over conventional coagulation (CC) include economic aspects (relatively low investment, maintenance, energy, and treatment costs), significantly lower volume of sludge produced, better sludge quality (lower water content, much larger and more stable flocs with better settlability), similar or slightly better efficiency, avoidance of chemical additions, ease of automation, simple equipment and compact size of EC systems (allowing decentralized treatment), greater functional $\mathrm{pH}$ range and $\mathrm{pH}$ neutralization effect, and the presence of electroflotation (EF) [5].

\subsection{Evaluation Principles}

The removal efficiencies ( $\mathrm{R} \%$ ) presented in Chapters 3.1 3.7 have been calculated with the Equation (11):

$$
R \%=\frac{c_{0}-c_{1}}{c_{0}} \times 100
$$

where $c_{0}$ and $c_{1}$ are pollutant concentrations before and after EC treatment, respectively. Hydraulic retention times (HRT, min) were calculated with Equation (12):

$$
H R T=V / Q
$$

where $Q$ is the flow rate $(1 / \mathrm{min})$. Current densities (i, $\mathrm{A} / \mathrm{m}^{2}$ ) can be calculated with the Equation (13):

$$
i=I / A_{\text {eff }}
$$

where $A_{\text {eff }}$ is the effective, submerged area of the anode $\left(\mathrm{m}^{2}\right)$. When no current density values were given by the authors, either the current or voltage value in optimum conditions is presented in Tables 1-7. The electrical energy consumption $\left(\mathrm{EEC}, \mathrm{kWh} / \mathrm{m}^{3}\right.$ ) presented in Chapters 3.1 - 3.7 has been calculated with the Equation (14):

$$
E E C=\frac{U \times I \times t}{60 \times V}
$$

where $U$ is the applied voltage $(V)$, $\mathrm{t}$ is the treatment time (min) and $V$ is the volume of the treated water $\left(\mathrm{dm}^{3}\right)$. Operating costs $\left(O C, € / \mathrm{m}^{3}\right)$ have been calculated with the Equation (15):

$$
O C=a \times E E C+b \times E M C
$$

where $a$ and $b$ are the current market prices of electricity $(€ / \mathrm{kWh})$ and electrode materials $(€ / \mathrm{kg})$, respectively, and EMC $\left(\mathrm{kg} / \mathrm{m}^{3}\right)$ is electrode material consumption. The market prices used in calculating economic value have varied slightly from one paper to another, depending on the country and year of publication (prices have been on the rise over time), but they have been within a very similar range. Derived from Equations (14) and (15), $E E C$ and $O C$ per $\mathrm{kg}$ of specific pollutant/parameter $\left(\mathrm{kWh} / \mathrm{kg}_{\mathrm{x}}\right.$ and $€ / \mathrm{kg}_{\mathrm{x}}$ ) can also be readily calculated based on the removal percentage and initial/final concentrations of the pollutant. These values have been presented also by some of the authors. The $\mathrm{pH}$ values presented in Tables 1-7 represent the range in which the EC application performed the best (the highest value is marked in brackets), even though the process would have performed nearly as well with $\mathrm{pH}$ values outside of this range. If the natural $\mathrm{pH}$ of the aqueous solution was inside this range, it has been noted separately.

In a handful of papers, the author did not present economic values and current densities in optimum conditions, but they could be approximated by using the values (total submerged anode surface area, applied current and voltage or current density, volume of the wastewater treated, treatment time, initial concentration, removal efficiency, etc.) given in the article. It should be strongly underlined that these rather simple calculations were done only when the authors of the corresponding papers had not presented the numbers themselves but had clearly stated the values needed for the calculations, or when the values could be easily deducted from the publication in question. The approximation calculations were based on Equations (11) and (13)-(15). Current market prices were estimated to be approximately $0.10-0.11$ $€ / \mathrm{kWh}$ (in Finland in July 2011, including electrical energy, distribution of electricity, and taxes) and 1.6 - 1.7 $€ / \mathrm{kg}$ for aluminum and $0.33-0.37 € / \mathrm{kg}$ for iron. These values are also similar to those used in the reviewed papers. All currencies (usually United States dollar) given in the papers for OC values have been converted to euros (in Tables 1-7) using up-to-date exchange rates.

Additionally, in some articles all the optimum values were not clearly stated or no specific values were given. In such cases, the missing values have been estimated, if possible, and if the results were reasonable and in line with the text. Estimations were based on the figures, tables, and text presented. Also, in a few papers additional optimum parameters were taken into account, meaning e.g. that when a major drop in treatment time, current density, or EEC-value was found to correspond with only a slight reduction in removal efficiency, the lesser removal efficiency (and corresponding other) values were also considered optimal in economic terms. Whenever any of these actions have been performed, it has 
Table 1. Recent applications of EC in the treatment of tannery, textile and colored wastewater.

\begin{tabular}{|c|c|c|c|c|c|c|c|c|c|c|c|c|c|c|c|}
\hline $\begin{array}{c}\text { Water \& } \\
\text { wastewater } \\
\text { types used }\end{array}$ & $\begin{array}{l}\text { Genuine } \\
\text { (G)/ } \\
\text { Synthetic } \\
\text { (S) water }\end{array}$ & $\begin{array}{l}\text { Anode/ } \\
\text { Cathode } \\
\text { material }\end{array}$ & $\begin{array}{l}\text { Reactor } \\
\text { type }\end{array}$ & $\begin{array}{c}\text { Volume } \\
\text { treated } \\
{[\mathrm{ml}]}\end{array}$ & $\begin{array}{l}\text { Optimum } \\
\text { electrode } \\
\text { gap }[\mathrm{mm}]\end{array}$ & $\begin{array}{c}\text { Optim } \\
\text { density } \\
\text { time an } \\
{\left[\mathrm{A} / \mathrm{m}^{2}\right.}\end{array}$ & $\begin{array}{l}\text { num cu } \\
y, \text { treat } \\
\text { nd initi } \\
\left.{ }^{2}\right],[\mathrm{min}\end{array}$ & $\begin{array}{l}\text { Irrent } \\
\text { tment } \\
\text { ial pH } \\
\text { n], [] }\end{array}$ & $\begin{array}{l}\text { Initial pollutant } \\
\text { levels [mg/l] }\end{array}$ & $\begin{array}{c}\text { Optimum } \\
\text { removal } \\
\text { efficiency } \\
{[\%]}\end{array}$ & $\begin{array}{c}\text { Optimum } \\
\text { EEC } \\
{\left[\mathrm{kWh} / \mathrm{m}^{3}\right]}\end{array}$ & $\begin{array}{c}\text { Optimum } \\
\text { EEC } \\
{\left[\mathrm{kWh} / \mathrm{kg}_{\mathrm{X}}\right]}\end{array}$ & $\begin{array}{c}\text { Optimum } \\
\text { OC } \\
{\left[€ / \mathrm{m}^{3}\right]}\end{array}$ & $\begin{array}{c}\text { Optimum } \\
\text { OC } \\
{\left[€ / \mathrm{kg}_{\mathrm{X}}\right]}\end{array}$ & $\begin{array}{c}\text { Research } \\
\text { group } \\
\& \text { Publication } \\
\text { year }\end{array}$ \\
\hline $\begin{array}{l}\text { Tannery } \\
\text { wastewater } \\
\text { containing } \\
\text { organic and } \\
\text { inorganic } \\
\text { pollutants }\end{array}$ & 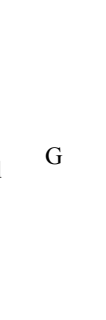 & $\mathrm{Fe}$ & Batch & 3000 & 50 & 22.4 & 20 & $\begin{array}{l}(7- \\
9)^{c}\end{array}$ & $\begin{array}{c}\text { COD: } 4100-6700 \\
\text { BOD: } 630-975 \\
\text { Cr: } 11.5-14.3 \\
\text { TSS: } 600-955 \\
\text { TKN: } 144-170 \\
\text { TDS: } \\
\text { 13300 - } 19700 \\
\text { O \& G: } 638-780 \\
\text { Color: } \\
\text { 3800 - 6330 } \\
\text { [Pt-Co] }\end{array}$ & $\begin{array}{l}\text { COD: } 95 \\
\text { BOD: } 96 \\
\text { Cr: } 100 \\
\text { TSS: } 96 \\
\text { TKN: } 62 \\
\text { TDS: } 50 \\
\text { O \& G: } 99 \\
\text { Color: } \sim 98^{\mathrm{g}}\end{array}$ & 0.13 & n.d. & 0.25 & n.d. & $\begin{array}{c}\text { Kongjao } \\
\text { et al. } 2008 \\
{[11]}\end{array}$ \\
\hline $\begin{array}{c}\text { Tannery } \\
\text { wastewater }\end{array}$ & G & $\mathrm{Fe}$ & Batch & 400 & 60 & 333 & $5 / 30^{\mathrm{h}}$ & $7.4^{\mathrm{d}}$ & $\begin{array}{c}\text { COD: } 3700 \\
\text { Sulfide: } 440 \\
\text { Cr } r_{\text {total }}: 22 \\
\text { SS: } 2690\end{array}$ & $\begin{array}{c}\text { COD: } \\
46^{\mathrm{g}} / 56^{\mathrm{h}} \\
\text { Sulfide: } \\
25 / 97^{\mathrm{h}} \\
\mathrm{Cr}_{\text {total }}: \\
\text { n.d. } / 97 \\
\text { SS: n.d. } / 70\end{array}$ & $\begin{array}{l}\sim(3.13 / \\
15.63- \\
16.49)^{\mathrm{e}}\end{array}$ & $\begin{array}{c}1.8 / \sim(9.0- \\
\left.9.5^{\mathrm{h}}\right) \\
\mathrm{kWh} / \mathrm{kg}_{\mathrm{COD}}\end{array}$ & n.d. & n.d. & $\begin{array}{l}\text { Apaydin } \\
\text { et al. } 2009 \\
{[26]}\end{array}$ \\
\hline $\begin{array}{c}\text { Industrial } \\
\text { textile } \\
\text { wastewater }\end{array}$ & G & $\mathrm{Al}$ & Batch & 2200 & 20 & 80 & 70 & $7^{\mathrm{c}}$ & $\begin{array}{c}\text { COD: } 1260 \\
\text { Turbidity: } 1310 \\
\text { [NTU] } \\
\text { TS: } 1750\end{array}$ & $\begin{array}{c}\text { COD: } 70 \\
\text { Turbidity: } \\
90 \\
\text { TS: } 50\end{array}$ & n.d. & n.d. & n.d. & n.d. & $\begin{array}{c}\text { Zodi } \\
\text { et al. } 2010 \\
{[28]}\end{array}$ \\
\hline $\begin{array}{l}\text { Wastewater } \\
\text { containing } \\
\text { dyes from } \\
\text { textile } \\
\text { industry } \\
\text { (Direct Red } \\
81 \text {, azo dye) }\end{array}$ & ) & $\mathrm{Al}$ & Batch & 500 & 15 & 18.75 & 60 & $\begin{array}{c}5-9 \\
{[6]}\end{array}$ & $\begin{array}{l}\text { Dye: } 25-200 \\
\text { (optimum 50) }\end{array}$ & Dye: 98 & n.d. & n.d. & n.d. & n.d. & $\begin{array}{c}\text { Aoudj } \\
\text { et al. 2010 } \\
{[29]}\end{array}$ \\
\hline $\begin{array}{c}\text { Dye- } \\
\text { containing } \\
\text { wastewater } \\
\text { (Direct Red } \\
23 \& \\
\text { Reactive } \\
\text { Blue 140) }\end{array}$ & $\mathrm{S} \times 2$ & $\mathrm{Fe}$ & $\begin{array}{l}\text { Continuous } \\
+ \\
\text { hydrogen } \\
\text { gas } \\
\text { collecting }\end{array}$ & 4420 & 8 & $30 / 40$ & $5 / 5$ & n.d. & Dye: $100 / 100$ & $\begin{array}{c}\text { COD: } \\
\text { 93/n.d. } \\
\text { Color: 99/89 } \\
\text { TS: } 89 / \text { n.d. }\end{array}$ & $0.69 / 1.42$ & n.d. & $>0.12$ & n.d. & $\begin{array}{c}\text { Phalakornkule } \\
\text { et al. } 2010 \\
{[30]}\end{array}$ \\
\hline $\begin{array}{c}\text { Blue } \\
\text { reactive } \\
\text { (Reactive } \\
\text { Blue 140), } \\
\text { red disperse } \\
\text { (Disperse } \\
\text { Red 1), } \\
\text { mixed dyes } \\
\text { and a real } \\
\text { textile } \\
\text { wastewater }\end{array}$ & $\mathrm{S} \times 3+\mathrm{G}$ & $\begin{array}{c}\mathrm{Al} \\
\mathrm{Fe}^{\mathrm{b}} \\
\mathrm{Al}-\mathrm{Fe}\end{array}$ & Batch & 1800 & 8 & $30-40$ & 5 & $\begin{array}{l}(7- \\
9.6)^{\mathrm{c}}\end{array}$ & $\begin{array}{l}\text { COD: } 278 \text { - } 736 \\
\text { Color: n.d. } \\
\text { TSS: } 85 \text { - } 354 \\
\text { TDS: } 1715 \text { - } 6106 \\
\text { TS: } 1800 \text { - } 6460\end{array}$ & $\begin{array}{l}\text { [COD: } \sim 90 / \\
\text { (55 - 79) } \\
\text { Color: } \\
\sim 100 / \\
(79-97) \\
\text { TSS: n.d./ } \\
\text { (55 - 96) } \\
\text { TDS: n.d./ } \\
(21-23) \\
\text { TS: } \text { n.d./ } \\
(26-28)]^{\mathrm{g}}\end{array}$ & $\begin{array}{l}\sim(0.3- \\
1.0)^{\mathrm{g} /} \\
(0.42- \\
1.62)^{\mathrm{g}}\end{array}$ & n.d. & n.d. & n.d. & $\begin{array}{c}\text { Phalakornkule } \\
\text { et al. } 2010 \\
{[31]}\end{array}$ \\
\hline $\begin{array}{l}\text { Crystal } \\
\text { violet } \\
\text { solution }\end{array}$ & $\mathrm{S}$ & $\underset{/ \mathrm{SS}^{\mathrm{b}}}{\mathrm{Al} / \mathrm{SSFe}}$ & Batch & 500 & 11 & 28 & 5 & 5.8 & $\begin{array}{c}\text { COD: n.d. } \\
\text { Dye: } 50 \text { - } 200 \\
\text { (optimum 200) }\end{array}$ & $\begin{aligned} \text { COD: } & \sim 100^{\mathrm{g}} \\
\text { Dye: } & \sim 96^{\mathrm{g}}\end{aligned}$ & 0.4 & n.d. & n.d. & n.d. & $\begin{array}{c}\text { Durango-Usuga } \\
\text { et al. } 2010 \\
{[32]}\end{array}$ \\
\hline $\begin{array}{l}\text { Acid green } \\
\text { dye } 50\end{array}$ & $\mathrm{~S}$ & $\mathrm{Al}$ & Batch & n.d. & 10 & 16.7 & 21 & $\begin{array}{c}6.9- \\
11 \\
{[9]}\end{array}$ & $\begin{array}{c}\text { COD: n.d. } \\
\text { Dye: } 100-300 \\
\text { (optimum 100) }\end{array}$ & $\begin{array}{l}\text { COD: } 87 \\
\text { Color: } 96^{\mathrm{g}}\end{array}$ & $\sim 0.48^{\mathrm{e}}$ & $\begin{array}{c}3.82 \\
\mathrm{kWh} / \mathrm{kg}_{\mathrm{COD}} \\
\sim 4.8 \\
\mathrm{kWh} / \mathrm{kg}_{\text {dye }}{ }^{\mathrm{g}}\end{array}$ & n.d. & n.d. & $\begin{array}{c}\text { El-Ashtoukhy } \\
\text { \& Amin } 2010 \\
{[33]}\end{array}$ \\
\hline $\begin{array}{c}\text { Acid brown } \\
14 \\
\text { (azo dye) }\end{array}$ & $\mathrm{S}$ & $\begin{array}{c}\mathrm{Al} \\
\mathrm{Al} / \mathrm{Fe}^{\mathrm{b}} \\
\mathrm{Fe}\end{array}$ & $\begin{array}{l}\text { Batch } \\
\text { Batch } \\
\text { (pilot } \\
\text { scale) }\end{array}$ & $\begin{array}{c}500 \\
9000\end{array}$ & $\begin{array}{l}10 \\
30\end{array}$ & $\begin{array}{c}6.329 \\
2.58\end{array}$ & $\begin{array}{c}18 \\
198\end{array}$ & $\begin{array}{l}4-6.4 \\
{[6.4]^{\mathrm{c}}}\end{array}$ & $\begin{array}{c}\text { COD: n.d. } \\
\text { Dye: } 30-100 \\
\text { (optimum 50) }\end{array}$ & $\begin{array}{r}\text { COD: } 87 \\
64 \\
\text { Color: } 91 \\
80\end{array}$ & $\begin{array}{c}\sim(0.053 \\
-0.037)^{\mathrm{e}}\end{array}$ & $\begin{array}{c}\sim(1.21- \\
1.15)^{\mathrm{e}} \\
\mathrm{kWh} / \mathrm{kg}_{\mathrm{COD}} \\
\sim(1.16- \\
0.92)^{\mathrm{e}} \\
\mathrm{kWh} / \mathrm{kg}_{\text {dye }}\end{array}$ & n.d. & n.d. & $\begin{array}{l}\text { Parsa } \\
\text { et al. } 2011 \\
\quad[34]\end{array}$ \\
\hline $\begin{array}{r}\text { Acid red } 14 \\
\text { (azo dye) }\end{array}$ & $\mathrm{S}$ & $\mathrm{Fe} /$ Steel & Batch & 250 & 10 & 100 & 4 & $\begin{array}{c}4-10 \\
{[7]}\end{array}$ & Dye: 50 & Color: 91 & n.d. & n.d. & n.d. & n.d. & $\begin{array}{c}\text { Aleboyeh } \\
\text { et al. } 2008 \\
{[35]}\end{array}$ \\
\hline
\end{tabular}




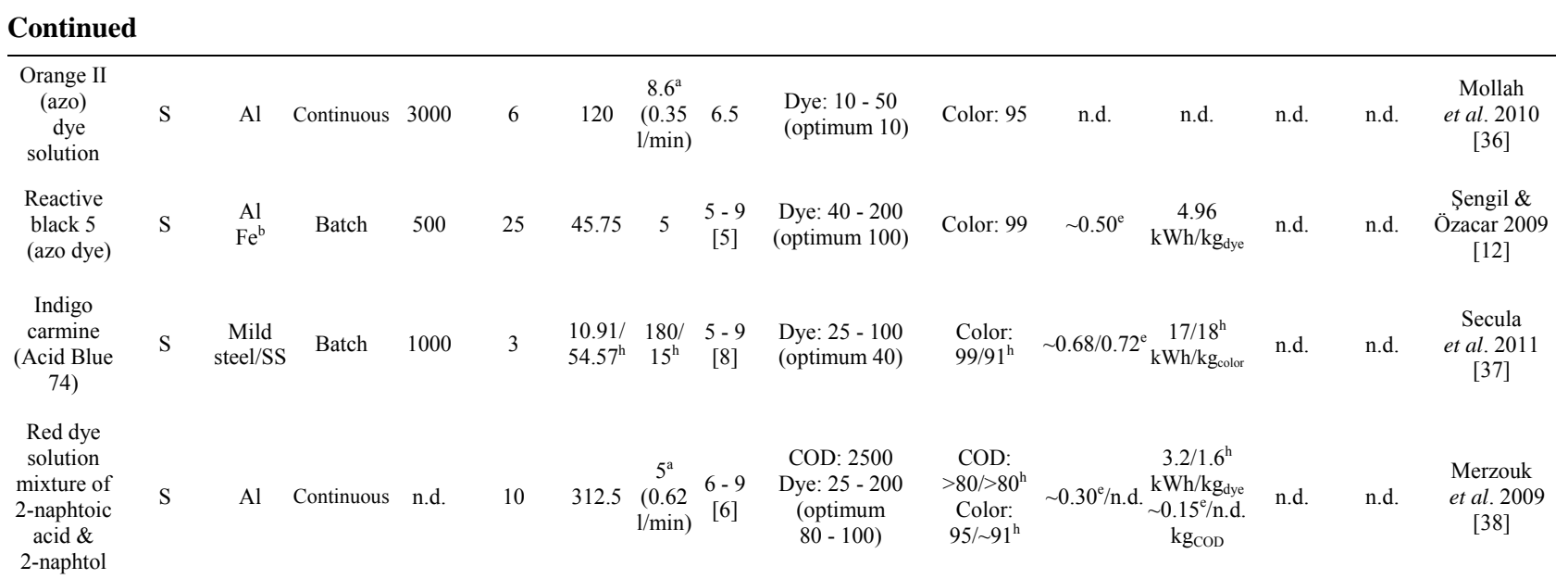

${ }^{\mathrm{a}}=$ HRT (hydraulic retention time) in EC systems with continuous mode of operation [min]; ${ }^{\mathrm{b}}=$ Observed as the best electrode configuration of those tested; ${ }^{\mathrm{c}}=$ The natural, unmodified $\mathrm{pH}$ value of the water or wastewater (found optimal); ${ }^{\mathrm{d}}=$ The natural, unmodified $\mathrm{pH}$ value of the water or wastewater (the effect of $\mathrm{pH}$ not researched); ${ }^{\mathrm{e}}=$ Approximation calculation based on values given in the article at issue; ${ }^{\mathrm{g}}=$ Optimum value estimated from the data in the article (precise value not given) $;{ }^{\mathrm{h}}=$ Additional "optimum value" estimated from the data in the article; n.d. $=$ Not determined.

been marked accordingly in Tables 1-7.

\section{Overview of Different Types of Water and Wastewater Recently Treated by Electrocoagulation}

Chapters 3.1 - 3.7 present a summary of recent applications of EC with different types of water and wastewater divided into categories by topic. Removal efficiencies, economic values and essential operational parameters in optimum process conditions are presented in Tables 1-7 along with other specifications (i.e. electrode materials, genuineness/artificiality and initial pollutant levels of the water, reactor type, volume of water treated, electrode gap) of the research in question. If multiple electrode materials were tested, the optimum values presented are for the electrode configuration found best (if any), which is noted in the corresponding columns in Tables 1-7.

\subsection{Tannery, Textile and Colored Wastewater}

The global tannery industry represents an important economic sector in many countries. The quantity of effluent generated is about 301 for every kilogram of hide or skin processed and it contains high concentrations of organic pollutants and $\mathrm{Cr}$ (III), which could be oxidized to highly toxic and carcinogenic $\mathrm{Cr}$ (VI) [22,23].

Dye-containing wastewaters are a major environmental concern because of their unaesthetic nature and their ability to hinder the penetration of light into water, which is detrimental to living organisms in bodies of water [24,25]. Azo dyes are one of the most widely used synthetic dyes. They can be toxic and mutagenic to aquatic life and are molecularly stable, rendering them resistant to biological and even chemical degradation [24]. Table 1 presents a summary of recent applications of EC in the treatment of tannery, textile and colored wastewater.

A study has been conducted on the treatment of wastewater from a tannery plant using the EC technique. A bench-scale system with iron electrodes was employed. The wastewater had high initial pollution parameter levels (see Table 1). After optimization, the EC treatment was found very effective and produced clear water (see Figure 1). The natural $\mathrm{pH}$ of the wastewater $(7.0$ - 8.7) was found to be within the optimum range of values. The EEC and OC values were found to be low, $0.13 \mathrm{kWh} / \mathrm{m}^{3}$ and $0.25 € / \mathrm{m}^{3}$, respectively. Parallel monopolar connections were found to be more suitable for the treatment process than monopolar serial and dipolar parallel connection modes [11]. Another investigation compared EC and $\mathrm{EF}$ (Electro-Fenton process - the addition of $\mathrm{H}_{2} \mathrm{O}_{2}$ to an EC process to bring about oxidation reactions) in treating genuine, highly polluted tannery wastewater [26]. It is worth mentioning that treatment of tannery wastewater by conventional biological methods is often inadequate for complete purification, especially of ammo-
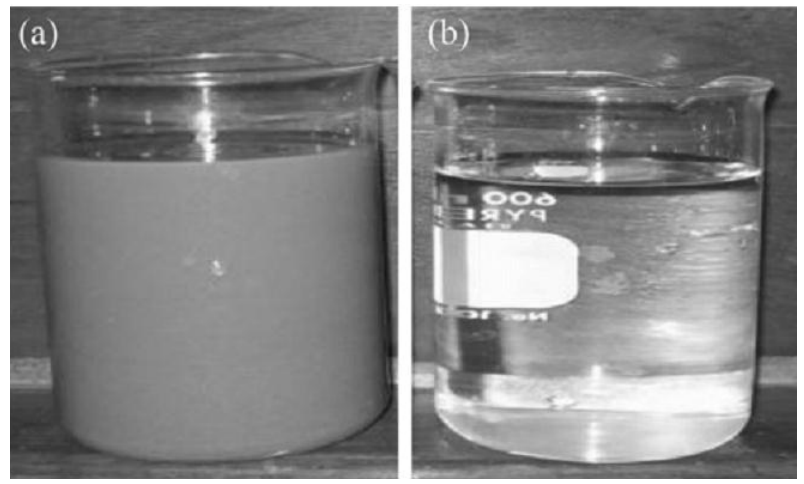

Figure 1. Tannery wastewater (a) before and (b) after treatment by electrocoagulation. Adapted from [11]. 
Table 2. Recent applications of EC in the treatment of paper industry wastewater.

\begin{tabular}{|c|c|c|c|c|c|c|c|c|c|c|c|c|c|c|c|}
\hline $\begin{array}{c}\text { Water \& } \\
\text { wastewater } \\
\text { types used }\end{array}$ & $\begin{array}{l}\text { Genuine } \\
(\mathrm{G}) / \\
\text { synthetic } \\
\text { (S) water }\end{array}$ & $\begin{array}{l}\text { Anode/ } \\
\text { cathode } \\
\text { material }\end{array}$ & $\begin{array}{l}\text { Reactor } \\
\text { type }\end{array}$ & $\begin{array}{c}\text { Volume } \\
\text { treated } \\
{[\mathrm{ml}]}\end{array}$ & $\begin{array}{l}\text { Optimum } \\
\text { electrode } \\
\text { gap }[\mathrm{mm}]\end{array}$ & $\begin{array}{l}\text { Optir } \\
\text { densi } \\
\text { time a } \\
{[\mathrm{A} / \mathrm{m}}\end{array}$ & $\begin{array}{l}\text { mum cu } \\
\text { ity, trea } \\
\text { and init } \\
\left.\mathrm{n}^{2}\right],[\mathrm{mi}\end{array}$ & $\begin{array}{l}\text { urrent } \\
\text { atment } \\
\text { tial pH } \\
\text { in], [] }\end{array}$ & $\begin{array}{c}\text { Initial pollutant } \\
\text { levels [mg/l] }\end{array}$ & $\begin{array}{c}\text { Optimum } \\
\text { removal } \\
\text { efficiency } \\
{[\%]}\end{array}$ & $\begin{array}{l}\text { Optimum } \\
\text { EEC } \\
{\left[\mathrm{kWh} / \mathrm{m}^{3}\right]}\end{array}$ & $\begin{array}{c}\text { Optimum } \\
\text { EEC } \\
{\left[\mathrm{kWh} / \mathrm{kg}_{\mathrm{X}}\right]}\end{array}$ & $\begin{array}{c}\text { Optimum } \\
\text { OC } \\
{\left[€ / \mathrm{m}^{3}\right]}\end{array}$ & $\begin{array}{l}\text { Optimum } \\
\text { OC } \\
{\left[€ / \mathrm{kg}_{\mathrm{X}}\right]}\end{array}$ & $\begin{array}{l}\text { Research } \\
\text { group \& } \\
\text { publication } \\
\quad \text { year }\end{array}$ \\
\hline $\begin{array}{c}\text { Black liquor } \\
\text { wastewater } \\
\text { (from pulp and } \\
\text { paper } \\
\text { industry) }\end{array}$ & d & $\begin{array}{l}\mathrm{Al}^{\mathrm{b}} \\
\mathrm{Fe}\end{array}$ & Batch & 300 & 5 & 140 & 50 & $\begin{array}{c}5-7 \\
{[7]}\end{array}$ & $\begin{array}{c}\text { COD: } 7960 \\
\text { Polyphenols: } \\
3220 \\
\text { Color: n.d. } \\
\text { TSS: } 1160\end{array}$ & $\begin{array}{c}\text { COD: } 98 \\
\text { Polyphenols: } \\
92 \\
\text { Color: } 99 \\
\text { TSS: n.d. }\end{array}$ & n.d. & n.d. & n.d. & n.d. & $\begin{array}{c}\text { Zaied } \\
\& \text { Bellakhal } \\
2009 \\
{[45]}\end{array}$ \\
\hline $\begin{array}{c}\text { Bleached kraft } \\
\text { mill } \\
\text { effluent } \\
\text { (pre-treated } \\
\text { by } \\
\text { sedimentation } \\
\text { \& aeration) }\end{array}$ & t & $\begin{array}{l}\mathrm{Al}^{\mathrm{b}} \\
\mathrm{Fe}\end{array}$ & Batch & 250 & 20 & 48 & $2 / 7.5^{\mathrm{h}}$ & $7.6^{d}$ & $\begin{array}{c}\text { COD: } 426 \\
\text { BOD: } 26 \\
\text { Lignin: } 13514 \\
\text { Phenol: } 0.535\end{array}$ & $\begin{array}{c}\text { COD: } \\
\sim 46^{\mathrm{g}} / 75^{\mathrm{h}} \\
\text { BOD: } \\
\sim 34^{\mathrm{g}} / 70^{\mathrm{h}} \\
\text { Lignin: } \\
\sim 79^{\mathrm{g}} / 80^{\mathrm{h}} \\
\text { Phenol: } \\
\sim 96^{\mathrm{g}} / 98^{\mathrm{h}}\end{array}$ & $\begin{array}{c}\sim(0.12 / \\
0.46)^{\mathrm{e}}\end{array}$ & $\begin{array}{c}\sim 120 / \sim 350 \\
\mathrm{kWh} / \mathrm{kg}_{\operatorname{COD}} \mathrm{g} \\
\sim 3.2 / \sim 9.5 \\
\mathrm{kWh} / \mathrm{kg}_{\text {lignin }} \mathrm{g}\end{array}$ & n.d. & n.d. & $\begin{array}{c}\text { Uğurlu } \\
\text { et al. } 2008 \\
{[46]}\end{array}$ \\
\hline $\begin{array}{c}\text { Paper mill } \\
\text { wastewater }\end{array}$ & $\mathrm{G}$ & $\begin{array}{c}\mathrm{Al} \\
\mathrm{Al} / \mathrm{Fe} \\
\mathrm{Fe} / \mathrm{Al} \\
\mathrm{Fe}\end{array}$ & Batch & 1500 & 10 & 700 & 30 & $(5-7)^{c}$ & $\begin{array}{c}\text { COD: } 1700 \\
\text { Color: n.d. } \\
\text { Phenol: } 34 \\
\text { BOD: } 850 \\
\text { TOC: } 910 \\
\text { TSS: } 1060 \\
\text { TS: } 9801\end{array}$ & $\begin{array}{c}\text { COD: } 86^{\mathrm{g}}(\mathrm{Fe}) \\
\text { Color: } 92^{\mathrm{g}} \\
(\mathrm{Al}) \\
\text { Phenol: } 96^{\mathrm{g}} \\
\text { (Fe) } \\
\text { BOD: } \text { n.d. } \\
\text { TOC: } \text { n.d. } \\
\text { TSS: n.d. } \\
\text { TS: } \text { n.d. }\end{array}$ & n.d. & n.d. & n.d. & n.d. & $\begin{array}{c}\text { Katal } \\
\& \\
\text { Pahlavanzadeh } \\
2011 \\
{[48]}\end{array}$ \\
\hline $\begin{array}{l}\text { Tissue paper } \\
\text { wastewater }\end{array}$ & G & $\mathrm{Al}$ & Batch & $\begin{array}{c}300 \\
4500 \\
\text { (scale- } \\
\text { up) }\end{array}$ & $\begin{array}{l}10 \\
10\end{array}$ & $\begin{array}{c}10.8- \\
16.2 \\
10.8\end{array}$ & $\begin{array}{l}30 \\
60\end{array}$ & $\begin{array}{l}(6.7- \\
7)^{d}\end{array}$ & $\begin{array}{c}\text { Turbidity: } 80 \text { - } \\
\text { 120 [NTU] } \\
\text { COD: } 2645 \\
\text { BOD: } 1688 \\
\text { TSS: } 205 \\
\text { TDS: } \\
1200 \text { - } 1600\end{array}$ & $\begin{array}{r}\text { Turbidity: } \\
92 \text { - } 97 \\
92 \\
\text { COD: n.d. } \\
50 \\
\text { BOD: n.d. } \\
60 \\
\text { TSS: n.d. } \\
\text { n.d. } \\
\text { TDS: n.d. } \\
\text { n.d. }\end{array}$ & $\begin{array}{c}0.62-1.17 \\
0.68\end{array}$ & n.d. & n.d. & n.d. & $\begin{array}{c}\text { Terrazas } \\
\text { et al. } 2010 \\
{[10]}\end{array}$ \\
\hline
\end{tabular}

${ }^{b}=$ Observed as the best electrode configuration of those tested; ${ }^{\mathrm{c}}=$ The natural, unmodified $\mathrm{pH}$ value of the water or wastewater (found optimal); ${ }^{\mathrm{d}}=$ The natural, unmodified $\mathrm{pH}$ value of the water or wastewater (the effect of $\mathrm{pH}$ not researched); ${ }^{\mathrm{e}}=$ Approximation calculation based on values given in the article at issue; ${ }^{\mathrm{g}}=$ Optimum value estimated from the data in the article (precise value not given); ${ }^{\mathrm{h}}=$ Additional "optimum value" estimated from the data in the article; n.d. $=$ Not determined.

nia and tannins (low biodegradability due to polyphenolic compounds) [27]. Biological treatment of wastewater containing resistant and toxic compounds requires long processing times and large treatment areas and generates high amounts of low-density sludge.

The experiments were repeated three times and the experimental error was found to be around 3\%. The results presented are for the EC process only. It was found that the EF process was $10 \%$ more efficient in removing pollutants while its energy consumption was $20 \%$ lower. However, the cost of adding hydrogen peroxide was not considered. It was concluded that both processes showed fast and efficient purification of tannery industry wastewater. Note that the latter number presented in Table $\mathbf{1}$ is a visual approximation of Figure 1 in the article, because the precise value was not given in the text [26].
Genuine dark-grey colored, turbid (initially 1310 NTU, nephelometric turbidity unit) textile wastewater was treated by a recirculated batch EC process using Al electrodes. The natural $\mathrm{pH}$ of the wastewater was 7 , which was also the optimum value, making addition of chemicals unnecessary. Optimization of removal efficiency with response surface methodology (RSM) corresponding to the Box-Behnken experimental design was successfully performed. Statistical testing of the model obtained was conducted using Fisher's statistical test for analysis of variance (ANOVA). Percentages of COD (chemical oxygen demand), TS (total solids) and turbidity removed were taken as the system responses, while current density, initial $\mathrm{pH}$, and treatment time were the input parameters [28].

A batch EC system with Al electrodes was proposed 
for decolorizing synthetic azo-dye-containing industrial wastewater. Direct Red 81-dye concentration was measured using ultraviolet-visible spectrophotometry (maximum absorbance at wavelength $I_{\max }=522 \mathrm{~nm}$ ). It should be noted that this procedure was also used to estimate dye concentrations in other works presented in Table $\mathbf{1}$ when synthetic dye solutions were used, employing relevant maximum intensities. In this study, however, four supporting electrolyte types were compared; of these, $\mathrm{NaCl}$ showed the best performance. This was suggested to be due to $\mathrm{Cl}^{-}$anions destroying the passivation layer formed on the aluminum electrode, leading to a greater rate of anodic dissolution. A decolorization rate of $98 \%$ was reached in optimum conditions [29].

Two different types of synthetic dye effluents were prepared and treated with an EC apparatus working in a continuous upflow mode. This EC system also applied a hydrogen gas collecting system. The dyes used to prepare the wastewater were azo-based Direct Red 23 and Reactive Blue 140. In Table 1, the first number presents the wastewater containing Direct Red 23; the latter is the wastewater with Reactive Blue 140. Experimental and theoretical maximum hydrogen yields were compared, denoting $89 \%$ - 94\% efficiency in the gas collecting system. The results showed that the energy yield of harvested hydrogen (converted to electricity for the EC process with an assumed efficiency of $50 \%$ ) could reduce the EEC-value of the EC process by $13 \%$ and $8.5 \%$ for Direct Red 23 and Reactive Blue 140 solutions, respectively. It was also stated that the high-quality hydrogen collected could also have been saved for use as a reactant in industrial processes. Decolorization rates of $99 \%$ and $89 \%$ for a 5 -min EC-run applying a current density of 30 $\mathrm{A} / \mathrm{m}^{2}$ and $40 \mathrm{~A} / \mathrm{m}^{2}$ were found to be the optimum conditions for the Direct Red 23 and Reactive Blue 140 solutions, respectively. EEC-values were found to be low and the $\mathrm{OC}$ of the EC system was calculated as being less than $0.12 € / \mathrm{m}^{3}[30]$.

A typical textile effluent may have fluctuating properties because it contains various types of dye molecules. Therefore, a study was set up to investigate the decolorization of two different dyes (Reactive Blue 140 and azo-based Disperse Red 1) and a mixed dye made of them. Real textile wastewater was also treated with the same batch-EC system. All three synthetic wastewaters had results very close to each other (both EEC-values and removal efficiencies, which showed complete decolorization), therefore their values are given as their approximate averages in Table 1, followed by the results for real wastewater. Three different electrode configurations were tested, of which iron electrodes proved to be superior. The same optimum parameter values that were used for the synthetic dyed wastewaters prior to it were also used for the treatment of real wastewater, thus these values might have not been optimal for it. Of the five EC tests run in these conditions, one seemed to have failed (it was not in line with the others) and was therefore ruled out [31].

A batch EC system was employed to treat a synthetic crystal violet $(\mathrm{CV})$ solution. $\mathrm{Na}_{2} \mathrm{SO}_{4}$ was used as the support electrolyte in this work, which claimed that $\mathrm{NaCl}$ was a controversial choice because of its possibility to form organic chlorine by-products. In this study, a twolevel full factorial experimental design $\left(2^{\mathrm{k}}\right)$ was employed to evaluate decolorization of the $\mathrm{CV}$ wastewater by EC. The levels of four variables (initial $\mathrm{pH}, \mathrm{CV}$ concentration, supporting electrolyte concentration, current density) were studied. Reduced empirical models for both $\mathrm{Al}$ and $\mathrm{Fe}$ anodes were proposed for $\mathrm{CV}$ removal with EC. The correlation percentages were $96 \%$ and $83 \%$ for $\mathrm{Al}$ and $\mathrm{Fe}$ anodes, respectively. Iron was found superior to aluminum in this application, and residual amounts of less than $1 \mathrm{mg} / \mathrm{l}$ of iron were detected after an optimal 5-min EC run, while color and COD were fully removed [32].

A comparison of EC and EO (electro-oxidation) in treating Acid Green dye 50-based synthetic wastewater was done. Both processes were carried out in novel cathodic $\mathrm{H}_{2}$-gas-stirred batch reactors. This was proposed to reduce the capital and operating costs of the reactor by making mechanical stirring unnecessary, provided that the EC cell is designed properly. EC was found more efficient: in optimum conditions, practically complete decolorization and a COD reduction of $87 \%$ versus $68 \%$ were accompanied by clearly lower energy consumption than what was achieved with EO. However, it was concluded that further studies on different types of dyes are needed to confirm this [33].

EC was employed to remove Acid Brown 14 from an aqueous solution by bench- $(500 \mathrm{ml})$ and pilot-scale $(9000 \mathrm{ml})$ batch processes. This type of dye was chosen because of its high level of usage in the textile industry. Aluminum was found superior to iron as the anode material for this application. Rather low values of current density $\left(6.329 / 2.58 \mathrm{~A} / \mathrm{m}^{2}\right)$ were found optimal for the batch- and pilot-scale systems, leading to very low EECvalues $\left(0.053 / 0.037 \mathrm{kWh} / \mathrm{m}^{3}\right)$ while achieving substantial removal efficiencies for COD and color. The EC process was concluded to be promising in treating azodye-containing wastewater [34].

Optimization of Acid Red 14 azo dye removal by a batch-EC (Fe/steel electrodes) process with RSM was performed. Evaluation was based on the simple and combined effects of three main independent parameters: current density, treatment time, and initial $\mathrm{pH}$ of the wastewater. The study showed clearly that RSM was suitable for optimizing the EC process operating conditions and maximizing dye removal $(91.27 \%$ in $4 \mathrm{~min}$, 
whereas $93.93 \%$ in 4.47 min was predicted by the model, see Figure 2). A high coefficient of determination $\left(\mathrm{R}^{2}=\right.$ 0.928 ) ensured satisfactory adjustment of the model derived from the experimental data [35].

A continuous EC system with a 450-ml electrolytic cell bearing aluminum electrodes was utilized in treating synthetic wastewater polluted with azo-based Orange II dye. In this experiment, it was found clearly evident that when operating in optimum conditions (near-neutral initial $\mathrm{pH}, 350 \mathrm{ml} / \mathrm{min}$ flow rate, $4 \mathrm{~g} / \mathrm{l}$ added $\mathrm{NaCl}$ ), the color of the dye solution had almost completely vanished. The EC apparatus was summarized to be simple to design and operate and is an inexpensive tool for treatment of dye-containing textile wastewater [36].

Treatment of other artificially colored wastewater by batch EC was investigated, with iron used as the electrode material due to its clear superiority over aluminum here. The dye used in the experiments was azo-based Reactive Black 5, which was chosen because of its extensive annual consumption rate. Complete decolorization of $100 \mathrm{mg} / \mathrm{l}$ initial dye concentration was achieved rapidly in $5 \mathrm{~min}$, by adding of $3 \mathrm{~g} / \mathrm{l} \mathrm{NaCl}$ and applying a current density of $45.75 \mathrm{~A} / \mathrm{m}^{2}$. Optimal initial $\mathrm{pH}$ was found to cover a broad range of $\mathrm{pH}$ values [12].

An Indigo Carmine (Acid Blue 74)-based aqueous solution was treated with a batch EC system employing mild steel/SS electrodes. The gap between the vertically positioned electrodes was only $3 \mathrm{~mm}$. Generation of green iron(II) hydroxide into the solution changed its color from dark blue to dark green and further to yellow brown. At the end of the EC process, stirring was halted and sedimentation and flotation occurred, and a removal efficiency of $96 \%$ was achieved in optimal conditions. The observed color change during the EC process is depicted in Figure 3. A wide range of initial $\mathrm{pH}$ values were found to be suitable for this application. It was also shown that controlling $\mathrm{pH}$ (preventing it from rising by acid addition) during the EC process was detrimental and limited the development of flocs, at least in this case. $\mathrm{NaCl}$ was proposed as a better choice than $\mathrm{Na}_{2} \mathrm{SO}_{4}$ as a supporting electrolyte [37].

A red dye solution of 2-naphtoic acid and 2-naphtol was treated with Al-EC in a continuous mode. The reactor consisted of two compartments, the first being the actual electrolytic cell and the second a settling compartment filled by overflow from the first one. The initial COD value of the solution was $2500 \mathrm{mg} / \mathrm{l}$ when the total concentration of the dye mixture was $100 \mathrm{mg}_{\mathrm{dye}} / \mathrm{l}$. Optimal results were achieved with a 14-min residence time (of which only $5 \mathrm{~min}$ in the EC compartment), resulting in $95 \%$ dye removal efficiency and a $3.2 \mathrm{kWh} / \mathrm{m}^{3}$ EECvalue. The EEC-value could still be halved by increasing the conductivity of the water by adding $\mathrm{NaCl}$, but this led to a slight reduction in removal efficiency. The high

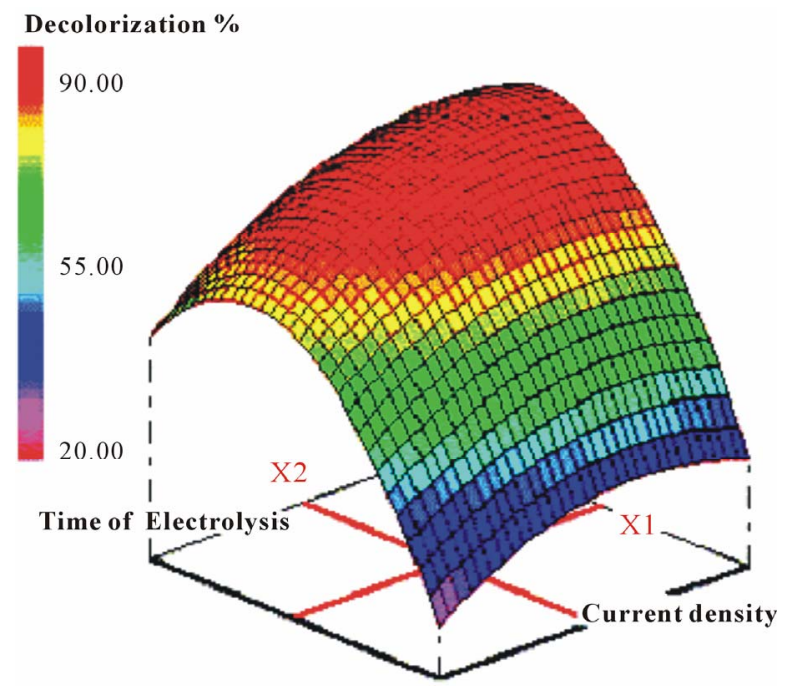

Figure 2. Three-dimensional contour plot obtained from the experimental data of color removal efficiency vs. current density (X1) and time of electrolysis (X2). Adapted from [35].

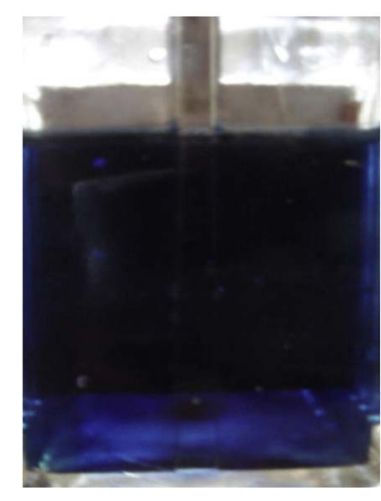

(a)

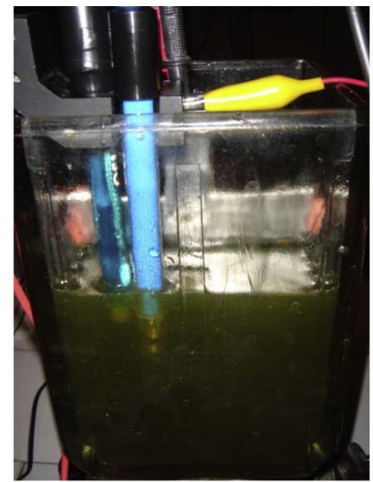

(c)

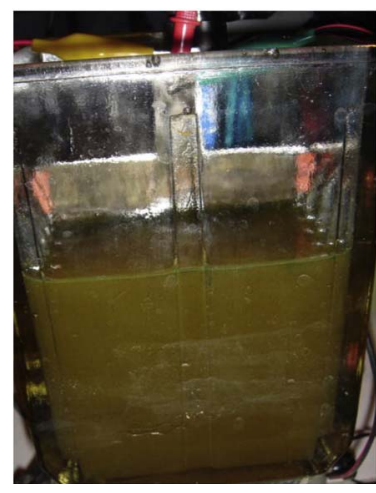

(b)

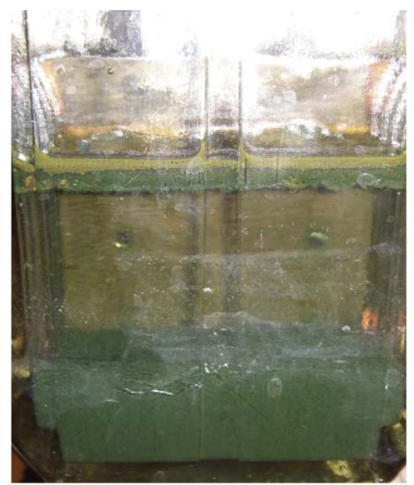

(d)
Figure 3. Evolution of the electrocoagulation process: (a) initial state; (b) $20 \mathrm{~min}, \mathrm{pH}=8.2$; (c) $40 \mathrm{~min}, \mathrm{pH}=9$; (d) $180 \mathrm{~min}$ of electrocoagulation and $5 \mathrm{~min}$ after stirring was turned off (initial concentration $=50 \mathrm{mg} / \mathrm{l}, \mathrm{pH}_{\text {initial }}=7.1$, current density $=10.91 \mathrm{~A} / \mathrm{m}^{2}$. Adapted from [37].

performance of EC in a continuous mode in removing this type of dye from wastewater was proven in this pa- 
per [38].

To summarize, EC treatment of tannery, textile, and colored waters has been under extensive development in recent years, with promising results. Wide research has been done in this field in addition to the studies presented in Table 1; e.g. those published in [8,25,39-43].

\subsection{Pulp and Paper Industry Wastewater}

The pulp and paper industry is one of the major waterintensive chemical process industries, contributing significantly to environmental pollution, e.g. in the form of black liquor. Blackish color, high amounts of organic load, suspended solids (mainly fibers), COD, and BOD (biological oxygen demand) are characteristic of effluents from pulp and paper industry. Arsenic may also be present. The strong color of the wastewater derives mainly from polymerization between lignin-degraded products and tannins. The drawbacks associated with conventional treatment techniques have made it necessary to develop more effective methods for treating this type of wastewater. Table 2 presents a summary of recent applications of EC in the treatment of pulp and paper industry wastewater [44].

Genuine black liquor wastewater with a high concentration of pollutants and a high $\mathrm{pH}$ value of 12 was treated with a batch EC system. The main characteristics of the wastewater before treatment are presented in Table 2. Repeatability tests were performed under the same experimental conditions. A relative standard deviation (R.S.D) value of less than 3\% was achieved, proving good repeatability of the EC process. Aluminum and iron were very close to each other in efficiency with different pollutants being removed. However, aluminum was slightly better overall and was chosen as the optimum. Also, Fe electrodes caused the water to turn green at first, and then to yellow and turbid due to $\mathrm{Fe}(\mathrm{II})$ and $\mathrm{Fe}(\mathrm{III})$ species generated, whereas the resulting effluent treated with $\mathrm{Al}$ was found very clear and stable [45].

The paper mill effluents from a modern bleached kraft mill were utilized in an EC study. The lignin concentration of the pretreated, brown effluent was extremely high, $13514 \mathrm{mg} / \mathrm{l}$. All experiments were repeated twice, and the experimental error was approximately 4\%. Aluminum was found superior to iron as the electrode material. The effect of initial $\mathrm{pH}$ was not studied in this work (the near-neutral original value was used). The high EECvalue of COD compared with that of lignin is related to its significantly lower initial concentration in the wastewater. The results of this study were found to suggest that EC is an effective alternative in paper mill effluent treatment [46].

Pre-treated wastewater from another paper mill with color, $\mathrm{pH}$, and $\mathrm{COD}$ similar to those in the previous study was treated by EC in a batch mode. The wastewater was constantly circulated in the EC system with a peristaltic pump. A settling test was also conducted in a separate $46-\mathrm{cm}-$ high glass column at the end of the test. All tests were done in triplicate. No clearly superior single electrode configuration could be found here, considering all aspects. Aluminium had somewhat better removal efficiency (except for lignin) than Fe, but the flocs it produced were clearly weaker in quality (SVI index values of $0.081-0.091 \mathrm{l} / \mathrm{g}$ and $0.207-0.310 \mathrm{l} / \mathrm{g}$ for $\mathrm{Fe}$ and $\mathrm{Al}$, respectively) and more difficult to handle. The research group concluded that they will therefore use $\mathrm{Fe}$ in their consecutive studies. However, $\mathrm{Al}$ was chosen as the optimum here based on raw efficiency numbers. EC was proposed as a very effective tool for treating wastewater of the paper industry [47].

Highly polluted paper mill wastewater was treated by EC. No clearly superior single electrode configuration could be found of the four that were tested. Using Fe caused color reduction to be only $62 \%$, and when using $\mathrm{Al}, \mathrm{COD}$ and phenol reductions were $77 \%$ and $91 \%$, respectively. Hybrid electrodes were the most constant in every parameter investigated, with results between those of $\mathrm{Al}$ and $\mathrm{Fe}$. It should be pointed out that the optimum current density suggested $\left(700 \mathrm{~A} / \mathrm{m}^{2}\right)$ was the highest one presented in Table 2 and significantly higher than in other studies. It was found that the water could be purified optimally directly without $\mathrm{pH}$ adjustment. After duplicating all tests, the experimental error was found to be below $4 \%$ [48].

Wastewater from the tissue paper industry was treated by EC with an aim to obtain water quality acceptable for reuse. Real wastewater with high pollution levels (see Table 2) was employed. A scale-up system of the Albatch EC process was also tried, with similar efficiencies and EEC-values. The results showed that a separation gap of $10 \mathrm{~mm}$ produces a faster build-up of sludge between electrodes. However, it yields more efficient removal of turbidity and lower energy consumption than larger gaps. EC was concluded to have proven to be an efficient method for removing turbidity from this type of wastewater, producing water of quality (8 NTU) suitable for reuse in the paper bleaching stage [10].

In addition to the studies presented in Table 2, at least $[44,49,50]$ have also recently contributed to EC research in this particular sector. On the whole, treating paper industry wastewater by EC seems to be a feasible alternative and a subject of interest.

\subsection{Oily Wastewater}

Oily wastewaters with greatly varying compositions and very high pollutant levels are generated by various sources, such as petroleum refineries, discharge of bilge 
and ballast water, workshops, petrol stations, rolling mills, restaurants, edible oil and soap factories, as well as other general industrial sources. Oil-in-water can be found as free-floating oil, as an unstable oil/water emulsion, and also as a highly stable oil/water emulsion, which are all difficult to treat [7,51].

Table 3 presents a summary of recent applications of $\mathrm{EC}$ in the treatment of oily wastewater. In addition to the studies presented in Table 3, also [14,52-61] have recently studied oily wastewater purification by EC with promising results, which shows that there is a high interest in EC research in the field of oily wastewater purification.

A synthetic industrial oil-in-water emulsion was prepared and treated with EC. The original oil concentration of the emulsion was 5\%, which corresponded to extremely high COD and turbidity values of $62300 \mathrm{mg} / \mathrm{l}$ and 29700 NTU, respectively. Nevertheless, very high RSM-optimized removal efficiencies of $90 \%$ for COD and $99 \%$ for turbidity were achieved in less than $22 \mathrm{~min}$ with ANOVA showing a high variance coefficient $\left(\mathrm{R}^{2}=\right.$ 0.998 ), ensuring satisfactory adjustment of the model with the experimental data [62].

Purification of oily wastewater resulting from washing the bilges of boats using EC working in a batch mode was studied. Iron was found to best $\mathrm{Al}$ as the electrode material. EC treatment with both materials was tested using monopolar (MP) and bipolar (BP) electrode configurations. The EEC- and OC-values for a MP configuration were found to be significantly lower than those of a BP configuration, whereas COD reductions were found rather similar, thus making Fe-MP the most feasible solution. The initial green color of the wastewater disappeared after EC treatment and the effluent became more transparent. A very low $\mathrm{OC}$ value was achieved along- side high removal efficiency. Note that in Table 3, $\mathrm{C}_{10^{-}}$ $\mathrm{C}_{50}$ stands for $\mathrm{C}_{10}-\mathrm{C}_{50}$-hydrocarbons (indicators of raw oil-based hydrocarbons) [63].

Sunflower oil refinery wastewater with a natural $\mathrm{pH}$ value as low as 1.4 and COD as high as $15000 \mathrm{mg} / \mathrm{l}$ was treated in a batch EC reactor with aluminum electrodes. $\mathrm{Na}_{2} \mathrm{SO}_{4}$ and PAC (poly aluminum chloride) were added to the water to increase its conductivity and enhance coagulation. The addition of $0.5 \mathrm{mg} / 1 \mathrm{PAC}$ raised the removal efficiency of COD from $94.5 \%$ to $98.9 \%$ in optimum conditions (see Table 3 ). A significant initial $\mathrm{pH}$ adjustment to 5 - 7 was found to be required for optimal functionality. The treated effluent was very clear and its quality exceeded the local direct discharge standard and therefore EC was found very efficient in treating this type of wastewater [64].

An industrial waste emulsion containing fluorescent penetrating oil used in aeronautics was treated with EC using Al electrodes. The parameters shown in Table 3 are for the industrial-scale EC system only, as in this study a successful two-step scale-up (from a batch mode laboratory system to continuous pilot- and industrialscale systems) of the EC process with very similar performance parameters was conducted. The values given for the aforementioned EC process in Table $\mathbf{3}$ were ones achieved after additional sand and carbon filters, which contributed approximately 5 - 10 additional percentage points to removal efficiency. In this study, the industrial-scale system used utilized an innovative partial re-circulation of sludge supernatant (see Figure $\mathbf{4}$ for a presentation of the EC process pilot prototype), which was found to enhance coagulation (increasing removal efficiency) without increasing the EEC-value and to diminish the sludge generation rate. This phenomenon was proposed to be due to introduction of a basal quantity of

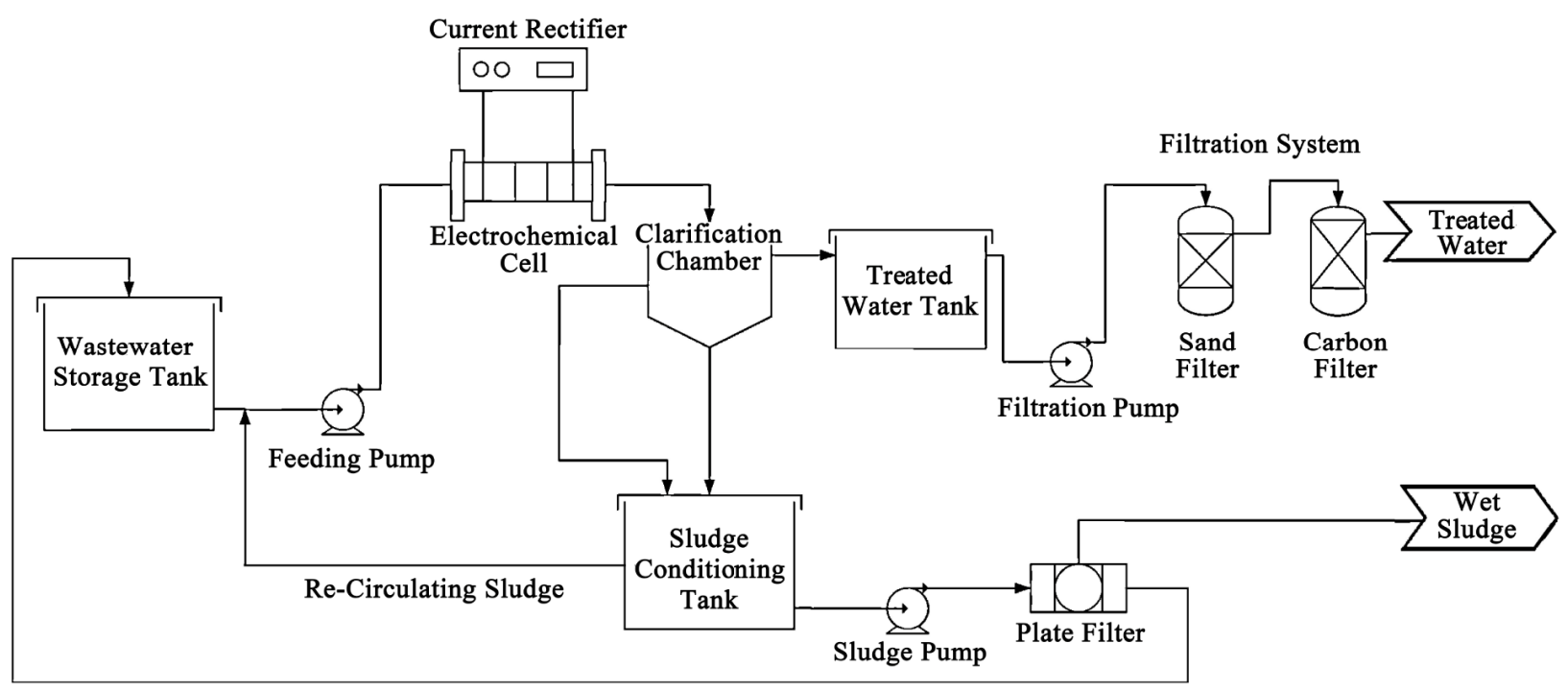

Figure 4. Scheme of the EC pilot prototype set up (see above). Adapted from [65]. 
Table 3. Recent applications of EC in the treatment of oily wastewater.

\begin{tabular}{|c|c|c|c|c|c|c|c|c|c|c|c|c|c|c|c|}
\hline $\begin{array}{l}\text { Water and } \\
\text { wastewater } \\
\text { types used }\end{array}$ & $\begin{array}{l}\text { Genuine } \\
\text { (G)/ } \\
\text { Synthetic } \\
\text { (S) water }\end{array}$ & $\begin{array}{l}\text { Anode/ } \\
\text { cathode } \\
\text { material }\end{array}$ & $\begin{array}{l}\text { Reactor } \\
\text { type }\end{array}$ & $\begin{array}{c}\text { Volume } \\
\text { treated } \\
{[\mathrm{ml}]}\end{array}$ & $\begin{array}{l}\text { Optimum } \\
\text { electrode } \\
\text { gap }[\mathrm{mm}]\end{array}$ & $\begin{array}{r}\text { Optin } \\
\text { densi } \\
\text { time } \\
\mathrm{pH}[\mathrm{A}\end{array}$ & $\begin{array}{l}\text { mum cu } \\
\text { ity, treat } \\
\text { e and ini } \\
\left./ \mathrm{m}^{2}\right],[\mathrm{m}\end{array}$ & $\begin{array}{l}\text { Irrent } \\
\text { tment } \\
\text { itial } \\
\text { nin], [] }\end{array}$ & $\begin{array}{c}\text { Initial } \\
\text { pollutant } \\
\text { levels } \\
{[\mathrm{mg} / \mathrm{l}]}\end{array}$ & $\begin{array}{l}\text { Optimum } \\
\text { removal } \\
\text { efficiency } \\
{[\%]}\end{array}$ & $\begin{array}{c}\text { Optimum } \\
\text { EEC } \\
{\left[\mathrm{kWh} / \mathrm{m}^{3}\right]}\end{array}$ & $\begin{array}{l}\text { Optimum } \\
\text { EEC } \\
{\left[\mathrm{kWh} / \mathrm{kg}_{\mathrm{x}}\right]}\end{array}$ & $\begin{array}{c}\text { Optimum } \\
\text { OC } \\
{\left[€ / \mathrm{m}^{3}\right]}\end{array}$ & $\begin{array}{l}\text { Optimum } \\
\text { OC } \\
{\left[€ / \mathrm{kg}_{\mathrm{X}}\right]}\end{array}$ & $\begin{array}{l}\text { Research } \\
\text { group }\end{array}$ \\
\hline $\begin{array}{l}\text { Industrial } \\
\text { oil-in-water } \\
\text { emulsion }\end{array}$ & $\mathrm{S}$ & $\mathrm{Al} / \mathrm{SS}$ & Batch & 400 & 10 & 250 & 22 & 7 & $\begin{array}{c}\text { COD: } 62300 \\
\text { Turbidity: } 29 \\
700[\mathrm{NTU}]\end{array}$ & $\begin{array}{c}\text { COD: } 90 \\
\text { Turbidity: } \\
99\end{array}$ & 3 & n.d. & n.d. & n.d. & $\begin{array}{c}\text { Tir \& } \\
\text { Moulai- } \\
\text { Mostefa } \\
2008[62]\end{array}$ \\
\hline $\begin{array}{c}\text { Oily } \\
\text { bilgewater }\end{array}$ & G & $\begin{array}{l}\mathrm{Al} \\
\mathrm{Fe}^{\mathrm{b}}\end{array}$ & Batch & 1700 & 15 & $\begin{array}{l}1.5[\mathrm{~A}] \\
=\sim 34^{\mathrm{e}}\end{array}$ & 60 & 4 & $\begin{array}{c}\text { COD: } \\
3350-3450 \\
\text { TOC - } 468 \\
\text { BOD }_{5}: \\
118-216 \\
\text { Turbidity: } \\
2210 \text { [NTU] } \\
\text { C }_{10}-\mathrm{C}_{50}: \\
422-460 \\
\text { O \& G: } 800 \\
\text { TSS: } 501-585 \\
\text { TS: } \\
2160 \text { - } 2400\end{array}$ & $\begin{array}{c}\text { COD: } 78 \\
\text { TOC: n.d. } \\
\text { BOD }{ }_{5}: \\
90-96 \\
\text { Turbidity: } \\
98 \text { - } 99 \\
\text { C }_{10} \text { C }_{50}: 99 \\
-100 \\
\text { O \& G: } 95 \\
-96 \\
\text { TSS: } \\
99-100 \\
\text { TS: } \\
32-43\end{array}$ & $\begin{array}{c}2.07- \\
2.25 \\
\end{array}$ & n.d. & $\begin{array}{c}0.032- \\
0.033\end{array}$ & n.d. & $\begin{array}{c}\text { Asselin et al. } \\
2008 \\
{[63]}\end{array}$ \\
\hline $\begin{array}{l}\text { Vegetable oil } \\
\text { refinery } \\
\text { wastewater }\end{array}$ & G & $\mathrm{Al}$ & $\begin{array}{c}\text { Batch } \\
\text { Batch + } \\
\text { PAC 0,5 } \\
\text { mg/l }\end{array}$ & 300 & 8 & 350 & 90 & $\begin{array}{c}5-7 \\
{[7]}\end{array}$ & COD: 15000 & $\begin{array}{r}\text { COD: } 95 \\
99\end{array}$ & n.d. & $\begin{array}{c}96 \\
\mathrm{kWh} / \mathrm{kg}_{\mathrm{COD}} \\
42 \\
\mathrm{kWh} / \mathrm{kg}_{\mathrm{COD}}\end{array}$ & $\begin{array}{l}\sim(0.39- \\
1.2)^{\mathrm{e}}\end{array}$ & $\begin{array}{c}0.026- \\
0.08 \\
€ / \mathrm{kg}_{\mathrm{COD}}\end{array}$ & $\begin{array}{c}\text { Un et al. } \\
2009 \\
{[64]}\end{array}$ \\
\hline $\begin{array}{c}\text { Industrial } \\
\text { wastewater } \\
\text { containing a } \\
\text { fluorescent } \\
\text { penetrant oil } \\
\text { (emulsion) }\end{array}$ & G & $\mathrm{Al}$ & $\begin{array}{l}\text { Continuous } \\
+ \text { sand- } \\
\text { and AC- } \\
\text { filtration }\end{array}$ & 23000 & 5 & 110 & $\begin{array}{c}5^{\mathrm{a}} \\
(3.2 \\
1 / \mathrm{min})\end{array}$ & $\begin{array}{l}(6.5- \\
7.5)^{\mathrm{d}}\end{array}$ & $\begin{array}{c}\text { COD: } \\
1000-2500 \\
\text { Color: } 350 \\
\text { [Pt-Co] } \\
\text { Turbidity: } 600 \\
\text { [NTU] }\end{array}$ & $\begin{array}{l}\text { COD: } 95 \\
\text { Color: } 99 \\
\text { Turbidity: } \\
99\end{array}$ & $\begin{array}{c}\sim(0.5- \\
0.7)^{\mathrm{g}}\end{array}$ & n.d. & $0.18^{\mathrm{g}}$ & n.d. & $\begin{array}{c}\text { Meas et al. } \\
2010 \\
{[65]}\end{array}$ \\
\hline $\begin{array}{c}\text { Olive mill } \\
\text { wastewater }\end{array}$ & $\begin{array}{c}\mathrm{G} \\
\text { (diluted } \\
\text { to } 20 \% \text { ) }\end{array}$ & $\mathrm{Al}$ & Batch & 100 & 28 & 250 & 15 & $(4-6)^{c}$ & $\begin{array}{c}\text { COD: } 20000 \\
\text { Polyphenols: } \\
260 \\
\text { Color: n.d. }\end{array}$ & $\begin{array}{c}\text { COD: } 84 \\
\text { Polyphenols: } \\
87 \\
\text { Color: } 92\end{array}$ & $\sim 5.26^{\mathrm{e}}$ & $\begin{array}{c}2.63 \\
\mathrm{kWh} / \mathrm{kg}_{\mathrm{COD}}\end{array}$ & $\sim 0.54^{\mathrm{e}}$ & $\begin{array}{c}0.27 \\
€ / \mathrm{kg}_{\mathrm{COD}}\end{array}$ & $\begin{array}{c}\text { Hanafi et al. } \\
2010 \\
{[66]}\end{array}$ \\
\hline $\begin{array}{l}\text { Waste metal } \\
\text { cutting fluids }\end{array}$ & G & $\begin{array}{l}\mathrm{Al} \\
\mathrm{Fe}^{\mathrm{b}}\end{array}$ & Batch & 800 & 10 & 60 & 25 & $\begin{array}{l}6-7 \\
{\left[7^{c}\right]}\end{array}$ & $\begin{array}{c}\text { COD: } 17312 \\
\text { TOC: } 3155 \\
\text { Turbidity: } \\
15350[\text { NTU] }\end{array}$ & $\begin{array}{c}\text { COD: } 92 \\
\text { TOC: } 82 \\
\text { Turbidity: } \\
100\end{array}$ & n.d. & n.d. & 0.348 & $\begin{array}{c}0.0016 \\
€ / \mathrm{kg}_{\mathrm{COD}} \\
0.0101 \\
€ / \mathrm{kg}_{\mathrm{TOC}}\end{array}$ & $\begin{array}{c}\text { Kobya et al. } \\
2008 \\
{[67]}\end{array}$ \\
\hline $\begin{array}{l}\text { Contaminated } \\
\text { groundwater } \\
\text { (petroleum } \\
\text { hydrocarbons) }\end{array}$ & G & $\begin{array}{c}\text { (Al, Fe \& } \\
\text { SS in } \\
\text { different } \\
\text { combinations) } \\
\text { SS/Fe }\end{array}$ & $\begin{array}{c}\text { Batch + } \\
\text { aeration } \\
\text { Continuous } \\
\quad+ \\
+ \\
\text { aeration }\end{array}$ & 200 & 30 & 180 & $\begin{array}{c}(20 / 40 \\
20 / 40^{\mathrm{a}} \\
{[0.01 /} \\
0.005 \\
1 / \mathrm{min}])^{\mathrm{g}}\end{array}$ & $\begin{array}{c}(6-9)^{\mathrm{c}} \\
{[7]}\end{array}$ & $\begin{array}{c}\text { TPH: } 64 \\
\text { TDS: } 1178\end{array}$ & $\begin{array}{c}\text { (TPH: } \\
\sim 85 / \sim 91 \\
\sim 81 / \\
\sim 91)^{\mathrm{g}} \\
\text { TDS: n.d. }\end{array}$ & n.d. & n.d. & n.d. & n.d. & $\begin{array}{c}\text { Moussavi et } \\
\text { al. } 2011 \\
{[68]}\end{array}$ \\
\hline $\begin{array}{c}\text { Palm oil-based } \\
\text { biodiesel } \\
\text { wastewater }\end{array}$ & G & $\begin{array}{c}\mathrm{Al} / \\
\text { Graphite }\end{array}$ & Batch & 1000 & 15 & $\begin{array}{l}20[\mathrm{~V}] \\
= \\
\sim 135- \\
140^{\mathrm{e}}\end{array}$ & 25 & 6 & $\begin{array}{l}\text { COD: } 30980 \\
\text { O \& G: } 6020 \\
\text { SS: } 340 \\
\text { Methanol: } \\
10667\end{array}$ & $\begin{array}{l}\text { COD: } 55 \\
\text { O \& G: } 97 \\
\text { SS: } 98 \\
\text { Methanol: } \\
\text { n.d. }\end{array}$ & 5.57 & n.d. & n.d. & n.d. & $\begin{array}{c}\text { Chavalparit } \\
\& \\
\text { Ongwandee } \\
2009 \\
{[70]}\end{array}$ \\
\hline $\begin{array}{c}\text { Rose oil } \\
\text { processing } \\
\text { wastewater }\end{array}$ & G & $\mathrm{Fe}$ & Batch & 400 & 65 & 80 & 20 & $\begin{array}{c}6.4- \\
7.1 \\
{[64]}\end{array}$ & $\begin{array}{c}\text { COD: } 9500 \\
\text { BOD: } 4950 \\
\text { Turbidity: } 750 \\
\text { [NTU] } \\
\text { TS: } 7690\end{array}$ & $\begin{array}{l}\text { COD: } 80 \\
\text { BOD: n.d. } \\
\text { Turbidity: } \\
81 \\
\text { TS: n.d. }\end{array}$ & 6.25 & 0.825 & n.d. & n.d. & $\begin{array}{c}\text { Avsar et al. } \\
2007 \\
{[71]}\end{array}$ \\
\hline
\end{tabular}

${ }^{\mathrm{a}}=$ HRT (hydraulic retention time) in EC systems with continuous mode of operation [min]; ${ }^{\mathrm{b}}=$ Observed as the best electrode configuration of those tested; ${ }^{\mathrm{c}}=$ The natural, unmodified $\mathrm{pH}$ value of the water or wastewater (found optimal); ${ }^{\mathrm{d}}=$ The natural, unmodified $\mathrm{pH}$ value of the water or wastewater (the effect of $\mathrm{pH}$ not researched); ${ }^{\mathrm{e}}=$ Approximation calculation based on values given in the article at issue; ${ }^{\mathrm{g}}=$ Optimum value estimated from the data in the article (precise value not given); n.d. = Not determined.

coagulant working as a coagulant initiator to the wastewater. The removal efficiency was high while the $\mathrm{OC}$ value was found to be very low. Cost estimates for the process indicated an investment-return time for the EC system of only about 17 weeks (at a rate of $8 \mathrm{~m}^{3}$ wastewater generated weekly at the plant) compared with the plant's current policy of simply sending it out for dis- posal [65].

Genuine olive mill wastewater (OMW), diluted with water to a fifth of the original concentration, was treated with EC an system using aluminum electrodes. Even after diluting the OMW, initial pollution concentrations were extremely high, as can be seen in Table 3 . All experiments were tripled, achieving accuracy better than 
$4 \%$. The naturally occurring $\mathrm{pH}$ of OMW and a 2-g/1 $\mathrm{NaCl}$ addition were found appropriate for achieving effective treatment, in which a significantly low EEC-value of $2.63 \mathrm{kWh} / \mathrm{kg}_{\mathrm{COD}}$ and very high removal efficiency (see Table 3) could be reached. The final $\mathrm{pH}$ of the OMW was nearly neutral. It was also found that the EC treatment reduced the toxicity of OMW for Bacillus cereus by $70 \%$. The growth of bacteria was nearly similar to a standard medium in the treated OMW, whereas in untreated OMW, bacterial growth was impossible. Consequently, EC was considered a viable pre-treatment step prior to a biological process for treating of OMW [66].

Metal cutting fluids are widely used for cooling and lubrication in metal industries. Batch EC treatment was performed on an extremely highly polluted (see Table 3) white-colored waste metal cutting fluid (WMCF) obtained from one such company's production of automotive engines, transmissions, and stamping plants. Iron was found to be clearly more economical than aluminum in treating the WMCF, even though removal efficiencies were very similar and high for both electrode materials. Operating costs were found to be low and the natural $\mathrm{pH}$ of WMCF was found to be optimal, thus addition of chemicals to alter the initial $\mathrm{pH}$ was unnecessary. It was concluded that despite achieving high COD reductions, further treatment is nonetheless needed because of the residual COD values, which still exceeded the local discharge standards [67].

The efficacy of EC for treating petroleum- contamnated groundwater (from a site close to a local petroleum refinery) was evaluated and quantified as total petroleum hydrocarbons (TPH) removed. $\mathrm{Al}, \mathrm{Fe}$, and $\mathrm{SS}$ in different combinations were tested as electrode materials, of which a SS/Fe-combination proved to be the most suitable. The EC process was studied with systems working in both batch and continuous modes. The natural neutral $\mathrm{pH}$ of the groundwater was found to be optimal and increasing HRT was found to improve TPH removal in the continuous EC systems. Note that the removal efficiencies shown in Table 3 were achieved with aeration in the EC cell, which added approximately 22 percentage points to the removal efficiencies (see Figure 5). This was proposed to be due to aeration-transferred oxygen accelerating the oxidation of $\mathrm{Fe}^{2+}$ (dissolved from the anode) in solution to $\mathrm{Fe}^{3+}$, which in turn resulted in formation of greater $\mathrm{Fe}(\mathrm{OH})_{3}$ flocs, thus improving TPH removal by adsorption. EC was summarized to be a promising technique in eliminating TPH from groundwater [68].

Biodiesel production generates large amounts of alkaline and highly oily wastewater with low nitrogen and phosphorus content, rendering it unable to be purified by biological treatment [69]. Such wastewater (with frying oil waste and crude palm oil used as biodiesel feedstock)

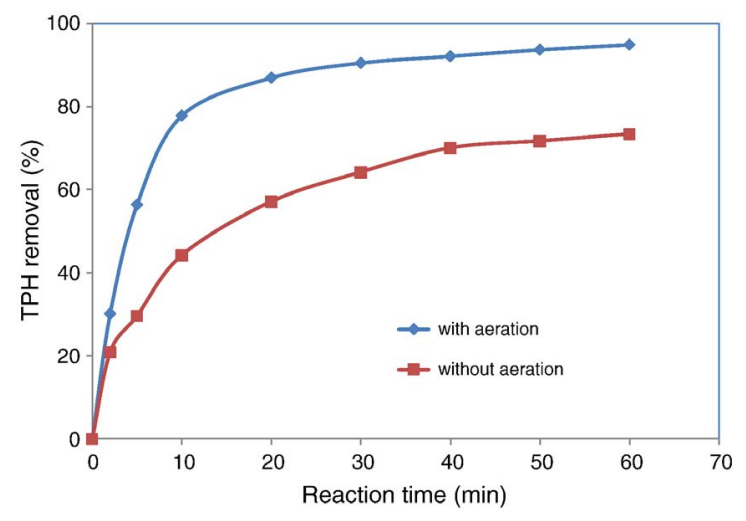

Figure 5. Effect of aeration on the removal of TPH in a batch-EC process (using Fe electrodes) as a function of reaction time. Adapted from [68].

was treated with a batch EC system using aluminum as the anode and (rather rarely) graphite as the cathode material. Box-Behnken design-based RSM optimization was applied to evaluate the best process conditions. The RSM results matched experimental values very well; the predicted optimum values for initial $\mathrm{pH}$, voltage, and reaction time were $6.06,18.2 \mathrm{~V}$, and $23.54 \mathrm{~min}$, respectively, with removal efficiencies all within 0.7 percentage points of those obtained experimentally. Ultimately, EC was found suitable as a primary treatment of biodiesel wastewater, which, however, still requires further biological treatment [70].

Industrial wastewater generated in rose oil processing was purified by EC. In a previous study by the same research group, Fe was proven better as the electrode material than $\mathrm{Al}$ for this type of wastewater. This was due to clearly lower residual metal concentrations, which were less than $0.2 \mathrm{mg} / \mathrm{l}$ with Fe. In this paper, CC, EF, and two different Fenton processes were compared. It was concluded that the EC process was most suitable for this type of wastewater, while CC performed the worst. Initial pollutant concentrations in the wastewater were very high (see Table 3). Note that even though 6.4 was found to be the optimum initial $\mathrm{pH}$ value, an acidic natural $\mathrm{pH}$ value of 4 was used to achieve the efficiencies presented in Table 3, because the difference in removal efficiencies was negligible [71].

\subsection{Food Industry Wastewater}

Wastewaters from agro-industries come from a myriad of sources and their compositions vary greatly. On the whole they are, however, characterized by high COD and BOD due to their high level of organic content [72]. Table 4 presents a summary of recent applications of EC in the treatment of food industry wastewater.

The dairy industry is associated with generation of huge amounts of wastewater (approximately 0.21 to 101 of effluent per liter of processed milk) that is high in nu- 
Table 4. Recent applications of EC in the treatment of food industry wastewater.

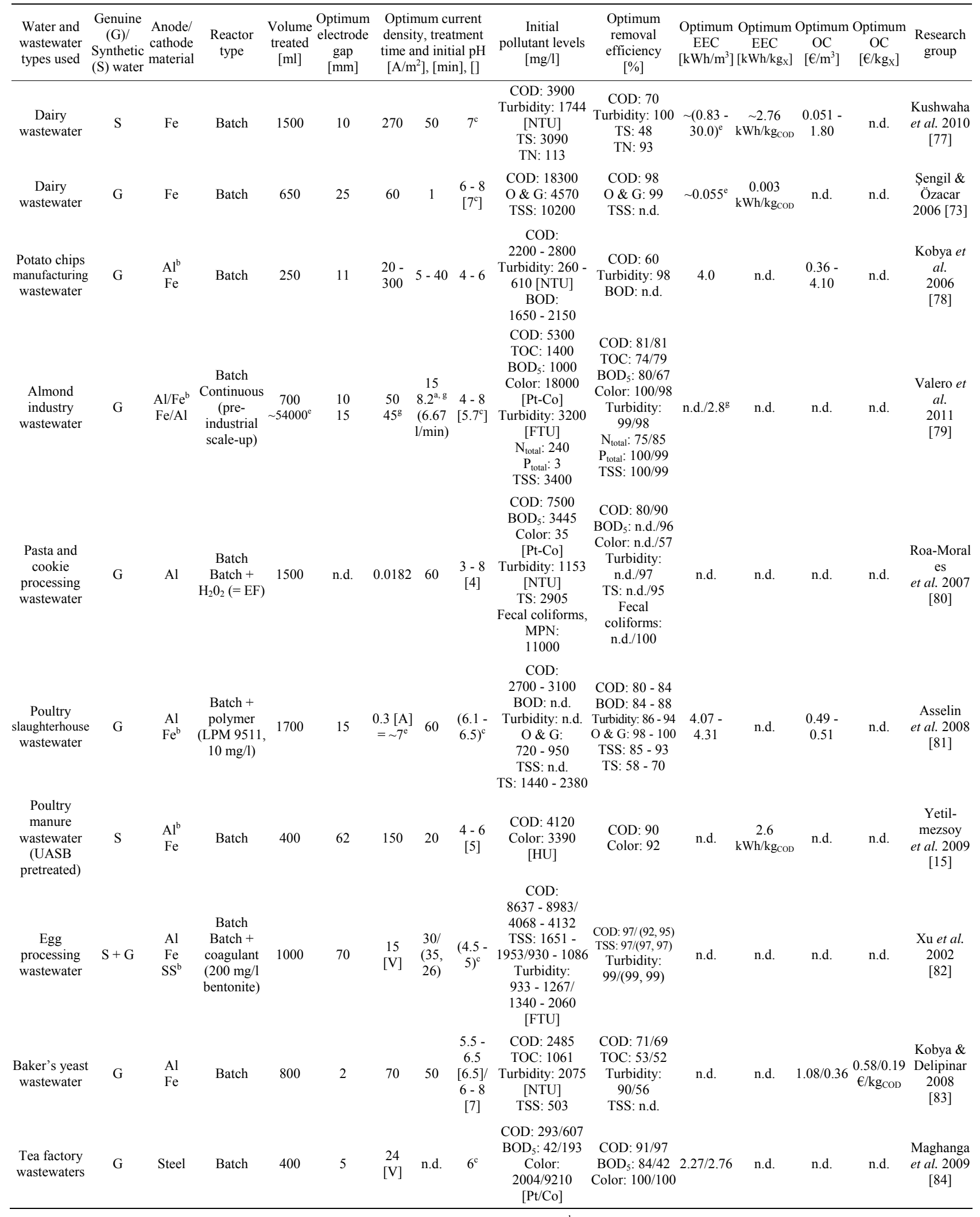

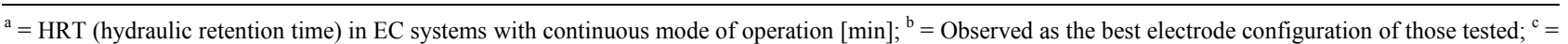
The natural, unmodified $\mathrm{pH}$ value of the water or wastewater (found optimal); ${ }^{\mathrm{e}}=$ Approximation calculation based on values given in the article at issue; ${ }^{\mathrm{g}}=$ Optimum value estimated from the data in the article (precise value not given); n.d. = Not determined. 
trients and has highly varied $\mathrm{pH}[73,74]$. In addition to those presented in Table 4, EC-treatment of dairy wastewater has been recently investigated by at least $[75,76]$. In a study on simulated dairy wastewater (SDW), a batch Fe-EC system was used coupled with a four-factor, fivelevel, full-factorial central composite design (CCD) based on RSM [77]. In optimum conditions, removal efficiency was high while economical values were low. Initial pollution levels of the SDW were high, with COD, TS, and turbidity being $3900 \mathrm{mg} / \mathrm{l}, 3090 \mathrm{mg} / \mathrm{l}$ and 1744 NTU, respectively. The authors suggested that, based on the results of TGA/DTA (thermal gravimetric analysis/ differential thermal analysis), the electrogenerated SDWsludge could be dried and used as fuel in boilers/incinerators or in fuel briquette production.

Real dairy effluent was treated by a Fe-EC system. Initial pollutant concentrations were very high; $18300 \mathrm{mg} / \mathrm{l}$ COD, $4570 \mathrm{mg} / \mathrm{l} \mathrm{O} \& \mathrm{G}$ (oil and grease), and 10200 $\mathrm{mg} / \mathrm{l}$ TSS (total suspended solids). Optimum treatment occurred very rapidly, as merely 1 min was found sufficient, while the EEC-value was extremely low $(0.003$ $\left.\mathrm{kWh} / \mathrm{kg}_{\mathrm{COD}}\right)$ and removal efficiencies were very high ( $98 \%$ and $99 \%$ of COD and O \& G, respectively). The equilibrium data obtained by the authors were found to fit very well into the Freundlich adsorption isotherm model $\left(\mathrm{R}^{2}=0.99\right)$ [73].

Potato chip manufacturing wastewater (PCW) was treated by batch-EC. Aluminum was found clearly superior to iron as the electrode material in this application. The removal efficiencies of COD and turbidity (having high initial values of $2200-2800 \mathrm{mg} / \mathrm{l}$ and $260-610$ NTU, respectively) were high; however no clear single set of optimum process conditions was proposed. The natural $\mathrm{pH}$ of the PCW was $6.2-6.5$, which was virtually optimal; therefore no $\mathrm{pH}$ adjustment was necessary. The results from kinetic studies showed that the kinetic data fit the second-order kinetic model very well $\left(\mathrm{R}^{2}>0.96\right)$ [78].

The results of batch and further continuous (removal efficiencies presented in Table $\mathbf{4}$ are in the form batch/ continuous) pre-industrial scale-up experiments showed that $\mathrm{EC}$ is an effective technology for treating wastewater from the almond industry, as the initially brown and murky wastewater turned colorless and clear as a result of EC treatment. Initial pollutant values were very high: e.g. 5300 - $6300 \mathrm{ppm}$ COD and 3200 - 4000 FTU (formazin turbidity unit) turbidity. The results obtained for $\mathrm{Al} / \mathrm{Fe}$ and $\mathrm{Fe} / \mathrm{Al}$ electrodes were very similar, however the first was chosen over the latter mainly for practical reasons. The treated water was found to satisfy wastewater discharge legislation and the electrogenerated sludge was discovered to be neutral and non-toxic. This work also proved that EC can also be transferred (see Table 4, very similar results) to an automated industrial scale. No
$\mathrm{pH}$ adjustment was required because the raw effluent had a $\mathrm{pH}$ value of 5.7, which was found optimal [79].

Wastewater from pasta and cookie processing was treated by an aerated batch -EC reactor after which the process was also investigated with added $\mathrm{H}_{2} \mathrm{O}_{2}(\mathrm{EF})$. The removal efficiencies presented in Table $\mathbf{4}$ are in the form $\mathrm{EC} / \mathrm{EF}$. The addition of $\mathrm{H}_{2} \mathrm{O}_{2}$ was found to raise the removal efficiency of COD from $80 \%$ to $90 \%$ with otherwise similar process conditions (values for other parameters with EC only were not given). The raw wastewater had very high initial pollutant values (see Table 4). A very interesting effect of total wastewater disinfection by EC was observed. The optimum initial $\mathrm{pH}$ range of EC was found to be very large in this application, being 3 8 [80].

Genuine red-orange-colored poultry slaughterhouse wastewater containing high amounts of organic matter (e.g. proteins, blood, fat) was treated by batch-EC using $\mathrm{Al}$ and $\mathrm{Fe}$ in monopolar (MP) and bipolar (BP) electrode configurations. The Fe-BP electrode configuration was found to be the most suitable here. Applying EC made the effluent more transparent and thus EC was found efficient for decolorization and clarification of poultry wastewater. After the optimum process conditions had been found, reproducibility tests were performed by repeating the EC test in triplicate. During these tests, 10 $\mathrm{mg} / \mathrm{l}$ of a cationic polymer was added to the treated effluents. It was thus verified that the EC process is highly effective, economical, and repeatable (see Table 4) for treating this type of wastewater [81].

The performance of a batch-EC system was investigated on UASB (up-flow anaerobic sludge bed)-pretreated artificially generated poultry manure wastewater. High removal efficiencies of $90 \%$ COD and $92 \%$ color were achieved with 20-min EC-treatment. In this study, a toxicity test was also conducted using small fish, Lebistes reticulatus, which showed that the EC-treated water did not cause any of the fish to die or behave abnormally during the 48-h test (a local environmental requirement) or even after extended 120-h exposure to the water. Aluminum was found to outperform $\mathrm{Fe}$ as the electrode material, mainly because of the greatly lower color reduction efficiency of iron, while for COD removal, aluminum was found only slightly more effective. The initial COD concentration of the water was $4120 \mathrm{mg} / \mathrm{l}$ and it was dark brown in color (3390 Hazen units). The EECvalue was given only at the natural initial $\mathrm{pH}$ of 8.82 , at which the results obtained were, however, very similar to those of $\mathrm{pH}$ 5. The results showed that almost $99.5 \%$ of the $\mathrm{Al}$ released precipitated in the form of EC sludge and the supernatant had an Al content of about $2.3 \mathrm{mg} / 1$ [15].

Simulated (SWS) and genuine egg processing industry wastewaters (EPW) with very high pollutant levels (see Table 4) were treated with batch-EC with multiple elec- 
trode compositions, of which SS was considered most suitable. The effect of adding $200 \mathrm{mg} / \mathrm{l}$ of bentonite coagulant was also studied using the real wastewater. The results presented in Table 4 are in the form SWS/(EPW, EPW + coagulant). The results obtained for both wastewaters showed very similar high removal efficiencies in a short treatment time. Additionally, EC yielded valuable by-products bearing high digestible protein and fat values. Addition of the coagulant further enhanced the EC process slightly. An economic analysis of EC indicated that this treatment is economically feasible and capital investments in equipment for a large-scale commercial egg processing plant could be recovered in 14 months [82].

Dark brown baker's yeast wastewater (BYW) with high pollution levels (see Table 4) was treated by batchEC. The results are presented in the form $\mathrm{Al} / \mathrm{Fe}$, because neither of the electrode materials used was proven to be universally superior to the other. Al was found to achieve slightly better removal efficiencies but at significantly higher operating costs. It was suggested that albeit the EC process could be adapted effectively for treatment of BYW, the effluent still contained a large amount of COD, which needed to be further treated by a secondary process [83].

Four wastewater samples $\left(\mathrm{SP}_{1}-\mathrm{SP}_{4}\right)$ were taken from different points in constructed wetlands following the outlet of a tea factory, and their treatment by batch-EC with steel electrodes was tested. The results presented in Table 4 are those of waters $\mathrm{SP}_{1} / \mathrm{SP}_{4}$. The results of waters $\mathrm{SP}_{2}$ and $\mathrm{SP}_{3}$ were found rather similar. The waters were highly colored before the EC-treatment (2004/9210 $\mathrm{mg} / \mathrm{l} \mathrm{Pt}-\mathrm{Co}$ ), however $100 \%$ color removal in all the samples, $\mathrm{SP}_{1}-\mathrm{SP}_{4}$, was recorded. $\mathrm{No} \mathrm{NaCl}$ was added to the wastewater samples even though their conductivities were low $(134-317 \mu \mathrm{S} / \mathrm{cm})$. Thus, it can be assumed that the energy consumption values could have been lower than the ones obtained. Diluting the waters prior to $\mathrm{EC}$ was found to be detrimental in terms of the EECvalue [84].

\subsection{Other Types of Industrial Wastewater}

Table 5 presents a summary of recent applications of EC in the treatment of other types of industrial wastewater.

Treatment of highly complex and highly polluted industrial wastewater (a mixture of wastewaters from 144 different factories received at a wastewater treatment plant) by batch-EC was studied. Three different electrode combinations were studied. Using aluminum and iron anodes simultaneously (corresponding cathodes were made of the same material as the anode) was found to outperform (better removal efficiencies, less sludge produced) the use of either metal alone as the anode material, combining the advantages of both. Complete disinfection of the wastewater was achieved. A short EC treatment time of 30 min resulted in almost similar (removal efficiencies only a few percentage points less) performance as a 60-min treatment time, for which the results are given in Table 5 [85].

Electroplating, metal finishing, and mining are industrial process in which large volumes of hazardous wastes containing heavy metals and free and metal cyanides are generated. Generally, cyanide removal from wastewater is carried out by chlorination, requiring high operating costs [86]. EC-treatment studies of separate cadmium and nickel electroplating rinse wastewaters (results in this order in Table 5) also containing high amounts of cyanide were carried out using iron electrodes in a batch mode. The raw $\mathrm{pH}$ values of both the wastewaters were found optimal. In optimum conditions (see Table 5), complete metal and cyanide removal was observed for both wastewaters, with OC-values of $1.05 € / \mathrm{m}^{3}$ (cadmium-laden wastewater) and $2.45 € / \mathrm{m}^{3}$ (nickel-laden wastewater) [87].

Removal of $\mathrm{Ni}, \mathrm{Cu}$, and $\mathrm{Cr}$ from very heavily polluted industrial galvanic wastewater was carried out by batchEC. The raw $\mathrm{pH}$ of the wastewater was 1.5 , which is strongly acidic, and adjustment to 5 was found necessary. The wastewater had very high conductivity $(41 \mathrm{mS} / \mathrm{cm})$ and its metal content was extremely high; around $2 \mathrm{~g} / \mathrm{l} \mathrm{Ni}$, $2.5 \mathrm{~g} / 1 \mathrm{Cu}$, and $0.7 \mathrm{~g} / 1 \mathrm{Cr}(70 \%$ present as $\mathrm{Cr}(\mathrm{VI}))$. The optimum electrode configuration of the EC system consisted of two separate anode-cathode-pairs used simultaneously instead of a single one made of $\mathrm{Al}$ or Fe. This novel EC process was found very efficient (see Table 5) in removing metals from galvanic wastewater. It was concluded that EC could be a good alternative or an after-treatment (the varying composition of such wastewaters may limit the feasibility of EC as a primary method) to conventional methods in this application [88].

Another study of $\mathrm{Ni}, \mathrm{Cu}$, and $\mathrm{Cr}$ removal from real industrial metal plating wastewater by batch-EC was conducted. The natural initial $\mathrm{pH}$ of the wastewater was 3 and it was chosen as "optimal" (optimal values presented in Table 5 given for this $\mathrm{pH}$ value) to avoid major addition of chemicals for $\mathrm{pH}$ adjustment, even though higher initial $\mathrm{pH}$ values $(7-9)$ resulted in higher metal removal efficiencies, which were also obtained significantly faster. A Fe/Al electrode configuration was found most suitable of the four combinations of $\mathrm{Al}$ and $\mathrm{Fe}$ tested, however $\mathrm{Fe} / \mathrm{Fe}$ was found to be nearly as efficient. In the end, it was concluded that EC in optimum process conditions could effectively reduce metal ions in the metal plating wastewater to a very low level, yielding $100 \%$ removal efficiencies for $\mathrm{Ni}, \mathrm{Cu}$, and $\mathrm{Cr}$ in $20 \mathrm{~min}$ [89].

Complexing agent and heavy metal $(\mathrm{Zn}, \mathrm{Ni})$ removal from a genuine, highly polluted metal plating effluent 
Table 5. Recent applications of EC in the treatment of other types of industrial wastewater.

\begin{tabular}{|c|c|c|c|c|c|c|c|c|c|c|c|c|c|c|c|}
\hline $\begin{array}{l}\text { Water and } \\
\text { wastewater } \\
\text { types used }\end{array}$ & $\begin{array}{l}\text { Genuine } \\
\text { (G)/ } \\
\text { Synthetic } \\
\text { (S) water }\end{array}$ & $\begin{array}{l}\text { Anode/ } \\
\text { cathode } \\
\text { material }\end{array}$ & $\begin{array}{l}\text { Reactor } \\
\text { type }\end{array}$ & $\begin{array}{c}\text { Volume } \\
\text { treated } \\
{[\mathrm{ml}]}\end{array}$ & $\begin{array}{l}\text { Optimum } \\
\text { electrode } \\
\text { gap [mm] }\end{array}$ & $\begin{array}{r}\text { Optim } \\
\text { densit] } \\
\text { time an } \\
{\left[\mathrm{A} / \mathrm{m}^{2}\right.}\end{array}$ & $\begin{array}{l}\text { mum cur } \\
\text { ty, treatr } \\
\text { and initia } \\
\left.\mathrm{n}^{2}\right],[\mathrm{min}\end{array}$ & $\begin{array}{l}\text { rrent } \\
\text { ment } \\
\text { al pH } \\
\text { 1], [] }\end{array}$ & $\begin{array}{c}\text { Initial } \\
\text { pollutant levels } \\
{[\mathrm{mg} / \mathrm{l}]}\end{array}$ & $\begin{array}{l}\text { Optimum } \\
\text { removal } \\
\text { efficiency } \\
{[\%]}\end{array}$ & $\begin{array}{l}\text { Optimum } \\
\text { EEC } \\
{\left[\mathrm{kWh} / \mathrm{m}^{3}\right]}\end{array}$ & $\begin{array}{l}\text { Optimum } \\
\text { EEC } \\
{\left[\mathrm{kWh}^{\mathrm{kg} g_{\mathrm{x}}}\right]}\end{array}$ & $\begin{array}{c}\text { Optimum } \\
\text { OC } \\
{\left[€ / \mathrm{m}^{3}\right]}\end{array}$ & $\begin{array}{c}\text { Optimum } \\
\text { OC } \\
{\left[€ / \mathrm{kg}_{\mathrm{x}}\right]}\end{array}$ & Research group \\
\hline $\begin{array}{c}\text { Highly } \\
\text { complex } \\
\text { industrial } \\
\text { wastewater } \\
\text { (a mixture of } \\
\text { wastewaters of } \\
144 \text { different } \\
\text { factories) }\end{array}$ & G & $\begin{array}{c}\mathrm{Al} \\
\mathrm{Fe} \\
(\mathrm{Al}+ \\
\mathrm{Fe})^{\mathrm{b}}\end{array}$ & Batch & $4000^{f}$ & 20 & 45.45 & 60 & $\begin{array}{l}6-8 \\
{\left[8^{c}\right]} \\
\end{array}$ & $\begin{array}{c}\text { COD: } 2000-2500 \\
\text { BOD }_{5}: 900-1050 \\
\text { Turbidity: } \\
1400-1800[\mathrm{NTU}] \\
\text { Color: } 2500-4750 \\
\text { [Pt-Co] } \\
\text { Fecal coliforms, } \\
\text { MPN: } 111000 \\
\text { TS: } 5360\end{array}$ & $\begin{array}{l}\text { COD: } 69 \\
\text { BOD } 5: 71 \\
\text { Turbidity: } \\
80 \\
\text { Color: } 83 \\
\text { Fecal } \\
\text { coliforms: } \\
\text { >99 } \\
\text { TS: n.d. }\end{array}$ & n.d. & n.d. & n.d. & n.d. & $\begin{array}{c}\text { Linares- } \\
\text { Hernández } \\
\text { et al. } 2009 \\
{[85]}\end{array}$ \\
\hline $\begin{array}{l}\text { Electroplating } \\
\text { rinse } \\
\text { wastewaters } \\
\text { containing } \\
\text { cadmium, } \\
\text { nickel and } \\
\text { cyanide }\end{array}$ & $\mathrm{G} \times 2$ & $\mathrm{Fe}$ & Batch & 650 & 10 & $30 / 60$ & $30 / 80$ & $\begin{array}{l}(7.6- \\
10.6)^{\mathrm{c}} / \\
(8- \\
10)^{\mathrm{c}} \\
{[10]}\end{array}$ & $\begin{array}{c}\text { Cd: } 102 /- \\
\text { Ni: }-/ 175 \\
\text { Cyanide: } 120 / 261 \\
\text { COD: } 180 / 220 \\
\text { TSS: } 175 / 185\end{array}$ & $\begin{array}{c}\text { Cd: } 99 /- \\
\text { Ni: }-/ 99 \\
\text { Cyanide: } \\
\text { 100/100 } \\
\text { COD: } \\
\text { n.d./n.d. } \\
\text { TSS: } \\
\text { n.d./n.d. }\end{array}$ & $6.13 / 11.94$ & n.d. & $1.05 / 2.45$ & n.d. & $\begin{array}{l}\text { Kobya } \\
\text { et al. } 2010 \\
{[87]}\end{array}$ \\
\hline $\begin{array}{c}\text { Galvanic } \\
\text { wastewater }\end{array}$ & G & $\begin{array}{c}\mathrm{Al} \\
\mathrm{Fe} \\
(\mathrm{Al}+\mathrm{Fe})^{\mathrm{b}}\end{array}$ & Batch & 1200 & 20 & $\begin{array}{l}(1.0[\mathrm{~A}] \\
+0.05 \\
[\mathrm{~A}])^{\mathrm{g}}\end{array}$ & 180 & 5 & $\begin{array}{l}\text { Ni: } 2000 \\
\text { Cu: } 2500 \\
\text { Cr: } 700\end{array}$ & $\begin{array}{l}\text { (Ni: } 95 \\
\mathrm{Cu}: 100 \\
\mathrm{Cr}: 95)^{\mathrm{g}}\end{array}$ & $4.3^{\mathrm{g}}$ & n.d. & n.d. & n.d. & $\begin{array}{c}\text { Heidmann \& } \\
\text { Calmano } 2010 \\
{[88]}\end{array}$ \\
\hline $\begin{array}{l}\text { Metal plating } \\
\text { wastewater }\end{array}$ & G & $\begin{array}{l}\mathrm{Al} / \mathrm{Al} \\
\mathrm{Al} / \mathrm{Fe} \\
\mathrm{Fe} / \mathrm{Fe} \\
\mathrm{Fe} / \mathrm{Al}^{\mathrm{b}}\end{array}$ & Batch & 650 & 10 & 100 & 20 & $\begin{array}{c}7-9 \\
{[9]}\end{array}$ & $\begin{array}{l}\text { Ni: } 394 \\
\text { Cu: } 45 \\
\text { Cr: } 44.5\end{array}$ & $\begin{array}{l}\text { Ni: } 100 \\
\text { Cu: } 100 \\
\text { Cr: } 100\end{array}$ & 10.07 & n.d. & n.d. & n.d. & $\begin{array}{c}\text { Akbal \& Camc1 } \\
2011 \\
{[89]}\end{array}$ \\
\hline $\begin{array}{c}\text { Complexed } \\
\text { wastewater } \\
\text { from metal } \\
\text { plating industry }\end{array}$ & G & SS & Batch & $1800^{\mathrm{f}}$ & 3 & 90 & 180 & $\begin{array}{l}6-8 \\
{\left[6^{c}\right]}\end{array}$ & $\begin{array}{l}\text { TOC: } 170-173 \\
\text { Zn: } 217-236 \\
\text { Ni: } 248-282\end{array}$ & $\begin{array}{l}\text { TOC: } 66 \\
\text { Zn: } 100 \\
\text { Ni: } 100\end{array}$ & n.d. & $\begin{array}{c}160 \\
\mathrm{kWh} / \mathrm{kg}_{\mathrm{TOC}} \\
70 \\
\mathrm{kWh} / \mathrm{kg}_{\mathrm{Ni}}\end{array}$ & n.d. & n.d. & $\begin{array}{c}\text { Kabdaşl1 } \\
\text { et al. 2009 } \\
{[90]}\end{array}$ \\
\hline $\begin{array}{l}\text { Automotive } \\
\text { assembly plant } \\
\text { rinse waters } \\
\text { from zinc } \\
\text { phosphate } \\
\text { coating }\end{array}$ & G & $\begin{array}{l}\mathrm{Al}^{\mathrm{b}, \mathrm{g}} \\
\mathrm{Fe}\end{array}$ & $\begin{array}{c}\text { Batch } \\
\text { Continuous }\end{array}$ & $\begin{array}{c}850 \\
3500\end{array}$ & $\begin{array}{l}11 \\
20\end{array}$ & $\begin{array}{l}60 \\
60\end{array}$ & $\begin{array}{c}25 \\
(0.4 / 0.1 \\
1 / \mathrm{min})^{\mathrm{g}}\end{array}$ & $\begin{array}{c}3-6 \\
{[5]}\end{array}$ & $\begin{array}{c}\text { COD: } 150 \\
\text { TOC: } 20 \\
\text { Turbidity: } 80 \\
\text { [NTU] } \\
\mathrm{Zn}^{2+}: 40 \\
\text { Phosphate: } 120 \\
\text { O \& G: } 10 \\
\text { TSS: } 240\end{array}$ & $\begin{array}{c}\text { (COD: } 77 \\
\text { TOC: } 65 \\
\text { Turbidity: } \\
98 \\
\mathrm{Zn}^{2+}: 97 \\
\text { Phosphate: } \\
99 \\
\text { O \& G: } 100 \\
\text { TSS-97) }\end{array}$ & $\begin{array}{l}\sim 4.8^{\mathrm{e}} \\
\text { n.d. }\end{array}$ & $\begin{array}{l}\text { n.d. } \\
\text { n.d. }\end{array}$ & $\begin{array}{c}\text { n.d. } \\
2.98 / 6.74\end{array}$ & $\begin{array}{l}\text { n.d. } \\
\text { n.d. }\end{array}$ & $\begin{array}{l}\text { Kobya } \\
\text { et al. 2010 } \\
{[91]}\end{array}$ \\
\hline $\begin{array}{l}\text { Chemical } \\
\text { mechanical } \\
\text { polishing } \\
\text { (CMP) } \\
\text { wastewater } \\
\text { from } \\
\text { semiconductor } \\
\text { fabrication }\end{array}$ & G & $\mathrm{Fe} / \mathrm{Al}$ & Batch & 500 & 20 & $20[\mathrm{~V}]$ & 20 & $\begin{array}{l}(8- \\
9)^{d}\end{array}$ & $\begin{array}{l}\text { COD: } 400-600 \\
\text { Turbidity: } 200- \\
300 \text { [NTU] } \\
\text { TOC: } 3 \text { - } 5 \\
\text { TSS: } 4000 \text { - } 5000\end{array}$ & $\begin{array}{l}\text { COD: } 85 \\
\text { Turbidity: } \\
\text { n.d. } \\
\text { TOC: } \text { n.d. } \\
\text { TSS: n.d. }\end{array}$ & 0.64 & n.d. & n.d. & n.d. & $\begin{array}{c}\text { Wang \& } \\
\text { Chou 2009 } \\
\text { [93] }\end{array}$ \\
\hline $\begin{array}{c}\text { Carwash } \\
\text { wastewater }\end{array}$ & G & $\begin{array}{l}\mathrm{Fe}+ \\
\mathrm{BDD}\end{array}$ & $\begin{array}{l}\text { Batch (EC) } \\
+ \text { Batch } \\
\text { (EO) }\end{array}$ & 300 & 15 & 20 & 6 & $\begin{array}{l}6-9 \\
{\left[6.4^{c}\right]}\end{array}$ & $\begin{array}{c}\text { COD: } 572 \\
\text { Surfactants: } 95.5 \\
\text { BOD: } 178\end{array}$ & $\begin{array}{l}\text { COD: } \\
75 / 97 \\
\text { Surfactants: } \\
\text { 100/100 } \\
\text { BOD: n.d. }\end{array}$ & $0.14 / 12.0$ & n.d. & n.d. & n.d. & $\begin{array}{c}\text { Panizza \& } \\
\text { Cerisola } 2010 \\
{[94]}\end{array}$ \\
\hline $\begin{array}{c}\text { Alcohol } \\
\text { distillery } \\
\text { wastewater }\end{array}$ & G & $\mathrm{Fe}$ & Batch & 1500 & 20 & 44.65 & 120 & 8 & $\begin{array}{l}\text { COD: } 15600 \\
\text { BOD: } 7200 \\
\text { TS: } 34100 \\
\text { TDS: } 2290\end{array}$ & $\begin{array}{l}\text { COD: } 51 \\
\text { Color: } 95 \\
\text { TS: n.d. } \\
\text { TDS: n.d. }\end{array}$ & n.d. & n.d. & n.d. & n.d. & $\begin{array}{l}\text { Kumar } \\
\text { et al. } 2009 \\
{[95]}\end{array}$ \\
\hline $\begin{array}{l}\text { Fermentation } \\
\text { industry } \\
\text { molasses } \\
\text { process water } \\
\text { (biologically } \\
\text { pre-treated) }\end{array}$ & G & $\begin{array}{l}\mathrm{Al} / \mathrm{SS}^{\mathrm{b}} \\
\mathrm{Fe} / \mathrm{SS}\end{array}$ & Batch & 6250 & 6 & 137 & 57 & $7.5^{\mathrm{d}}$ & $\begin{array}{l}\text { COD: } 4500 \\
\text { Color: n.d. } \\
\text { TDS: } 1600\end{array}$ & $\begin{array}{l}\text { COD: } 70 \\
\text { Color: } 95 \\
\text { TDS: n.d. }\end{array}$ & n.d. & n.d. & n.d. & n.d. & $\begin{array}{l}\text { Ryan } \\
\text { et al. 2008 } \\
{[96]}\end{array}$ \\
\hline $\begin{array}{c}\text { Coking } \\
\text { wastewater }\end{array}$ & G & $\mathrm{Fe} / \mathrm{Ti}$ & Continuous & 2000 & 10 & 300 & $\begin{array}{c}80^{\mathrm{a}} \\
(0.025 \\
1 / \mathrm{min})\end{array}$ & $\begin{array}{c}8-11 \\
{[8]}\end{array}$ & $\begin{array}{c}\text { Color: n.d. } \\
\text { COD: } 91-111 \\
\text { BOD }: 18-28 \\
\mathrm{NH}_{3}-\mathrm{N}: 4.8-5.8\end{array}$ & $\begin{array}{l}\text { Color: } 91 \\
\text { COD: n.d. } \\
\text { BOD }_{5}: \text { n.d. } \\
\mathrm{NH}_{3}-\mathrm{N}: \\
\text { n.d. }\end{array}$ & n.d. & n.d. & n.d. & n.d. & $\begin{array}{l}\text { Zhang } \\
\text { et al. 2011 } \\
\text { [97] }\end{array}$ \\
\hline $\begin{array}{l}\text { Antimony mine } \\
\text { flotation } \\
\text { wastewater }\end{array}$ & G & $\mathrm{Al}$ & Batch & 500 & 10 & 166.67 & 60 & $\begin{array}{c}2-6 \\
{[2]}\end{array}$ & $\begin{array}{c}\mathrm{Sb}_{\text {total }}: 10.4-28.6 \\
\mathrm{As}_{\text {total }}: 0.010- \\
0.025 \\
\mathrm{SBX}: 0.376- \\
0.434 \\
\mathrm{Ca}^{2+}: 360-389 \\
\mathrm{Mg}^{2+}: 25\end{array}$ & $\begin{array}{c}\mathrm{Sb}_{\text {total }}: \\
97-98 \\
\mathrm{As}_{\text {total }}: 100 \\
\mathrm{SBX}: \\
71-77 \\
\mathrm{Ca}^{2+}: \text { n.d. } \\
\mathrm{Mg}^{2+}: \text { n.d. }\end{array}$ & n.d. & n.d. & n.d. & n.d. & $\begin{array}{c}\text { Zhu et al. } 2011 \\
\text { [98] }\end{array}$ \\
\hline
\end{tabular}




\begin{tabular}{|c|c|c|c|c|c|c|c|c|c|c|c|c|c|c|c|}
\hline $\begin{array}{c}\text { Laundry } \\
\text { wastewater }\end{array}$ & G & $\mathrm{Al}$ & Batch & 1500 & 15 & $\begin{array}{l}1.32 \\
{[\mathrm{~A}]}\end{array}$ & 45 & $\begin{array}{l}(6- \\
8)^{c}\end{array}$ & $\begin{array}{c}\text { COD: } 4155 \\
\text { Turbidity: } 245 \\
\text { [NTU] } \\
\text { P: } 27.6 \\
\text { Detergent: } 463 \\
\text { Color: } 1430 \text { [n.d.] } \\
\text { SS: } 987 \\
\text { Pb: } 4.35 \\
\text { Zn: } 3.2\end{array}$ & $\begin{array}{c}\text { COD: } 93 \\
\text { Turbidity: } \\
\text { 96, P: } 97 \\
\text { Detergent: } \\
94 \\
\text { Color: } 90 \\
\text { SS: n.d. } \\
\text { Pb: n.d. } \\
\text { Zn: n.d. }\end{array}$ & $\sim 19.8^{\mathrm{e}}$ & n.d. & n.d. & n.d. & $\begin{array}{c}\text { Janpoor } \\
\text { et al. 2011 } \\
\text { [99] }\end{array}$ \\
\hline $\begin{array}{c}\text { Paint } \\
\text { manufacturing } \\
\text { wastewater }\end{array}$ & G & $\begin{array}{l}\mathrm{Al}^{\mathrm{b}} \\
\mathrm{Fe}\end{array}$ & Batch & 800 & 10 & 35 & 15 & $\begin{array}{l}4-8 \\
{[7]^{c}}\end{array}$ & $\begin{array}{c}\text { COD: } 19700 \\
\text { TOC: } \text { n.d. } \\
\text { SS: } 1100 \\
\text { Pb: } 1.44 \\
\mathrm{Fe}_{\text {tot }}: 4.82\end{array}$ & $\begin{array}{l}\text { COD: } 94 \\
\text { TOC: } 89 \\
\text { SS: n.d. } \\
\text { Pb: n.d. } \\
\text { Fe }_{\text {tot: }} \text { n.d. }\end{array}$ & n.d. & n.d. & 0.129 & n.d. & $\begin{array}{c}\text { Akyol } 2012 \\
{[101]}\end{array}$ \\
\hline $\begin{array}{c}\text { Marble } \\
\text { processing } \\
\text { wastewaters }\end{array}$ & G & $\begin{array}{l}\mathrm{Al}^{\mathrm{b}} \\
\mathrm{Fe}\end{array}$ & Batch & 250 & 5 & 15 & $0.5^{\mathrm{h}} / 2$ & $\begin{array}{c}(8- \\
9)^{\mathrm{c}}[9]\end{array}$ & $\begin{array}{c}\text { Turbidity: } 2640 \\
\text { [FTU] } \\
\text { SS: } 5178 \\
\text { TDS: } 0.21 \\
\text { O \& G: } 20\end{array}$ & $\begin{array}{c}\text { Turbidity: } \\
99^{\mathrm{h}} / 100 \\
\text { SS: } 99^{\mathrm{h}} / 100 \\
\text { TDS: } \\
\text { n.d./n.d. } \\
\text { O \& G: } \\
\text { n.d./n.d. }\end{array}$ & $\begin{array}{c} \\
\sim 0.0568^{\mathrm{e}} / \sim \\
0.227^{\mathrm{e}}\end{array}$ & $\begin{array}{c}\sim 0.0091^{\mathrm{e}} / 0 \\
.0363 \\
\mathrm{kWh} / \mathrm{kg}_{\mathrm{ss}}\end{array}$ & $\begin{array}{c}\sim 0.0155^{\mathrm{e}} / 0 \\
062\end{array}$ & $\begin{array}{c}0 . \sim 0.0025^{\mathrm{e}} / 0 \\
.01\end{array}$ & $\begin{array}{c}\text { Solak } \\
\text { et al. 2009 } \\
{[102]}\end{array}$ \\
\hline $\begin{array}{l}\text { Industrial } \\
\text { aqueous } \\
\text { solution } \\
\text { containing } \\
\text { polyvinyl } \\
\text { alcohol (PVA) }\end{array}$ & $\mathrm{S}$ & $\begin{array}{c}\mathrm{Al} / \mathrm{Al} \\
\mathrm{Al} / \mathrm{Fe} \\
\mathrm{Fe} / \mathrm{Al}^{\mathrm{b}} \\
\mathrm{Fe} / \mathrm{Fe}\end{array}$ & Batch & 500 & 20 & $10[\mathrm{~V}]$ & 120 & $6.5^{\mathrm{d}}$ & PVA: 100 & PVA: 77 & $\sim 1.57^{\mathrm{e}}$ & $\begin{array}{c}15.68 \\
\mathrm{kWh} / \mathrm{kg}_{\mathrm{g}}\end{array}$ & n.d. & n.d. & $\begin{array}{c}\text { Chou et al. } \\
2010 \\
{[103]}\end{array}$ \\
\hline $\begin{array}{l}\text { Industrial } \\
\text { aqueous } \\
\text { solution } \\
\text { containing } \\
\text { salisylic acid } \\
\text { (SA) }\end{array}$ & $\mathrm{S}$ & $\mathrm{Al}$ & Batch & 500 & 20 & 12 & $60^{\mathrm{g}}$ & n.d. & SA: 100 & SA: $87^{\mathrm{g}}$ & n.d. & $\begin{array}{c}0.00037 \\
\mathrm{kWh} / \mathrm{kg}_{\mathrm{SA}}\end{array}$ & n.d. & n.d. & $\begin{array}{c}\text { Chou et al. } \\
2011 \\
{[104]}\end{array}$ \\
\hline $\begin{array}{c}\text { Water } \\
\text { distribution } \\
\text { system water }\end{array}$ & G & $\mathrm{Fe}$ & Batch & 1300 & 20 & $12[\mathrm{~V}]$ & 60 & 10 & $\begin{array}{c}\text { Calcium } \\
\text { hardness: } 138 \\
{\left[\mathrm{mg} / \mathrm{l} \mathrm{CaCO} \mathrm{Ca}_{3}\right]} \\
\text { Total hardness: } \\
300 \\
{\left[\mathrm{mg} / 1 \mathrm{CaCO}_{3}\right]} \\
\text { Turbidity: } 3 \\
{[\mathrm{NTU}]}\end{array}$ & $\begin{array}{c}\text { Calcium } \\
\text { hardness: } \\
98 \\
\text { Total } \\
\text { hardness: } \\
97 \\
\text { Turbidity: } \\
\text { n.d. }\end{array}$ & n.d. & n.d. & n.d. & n.d. & $\begin{array}{c}\text { Malakootian et } \\
\text { al. 2010 } \\
\text { [105] }\end{array}$ \\
\hline $\begin{array}{c}\text { Municipal } \\
\text { wastewater }\end{array}$ & G & SS & Batch & $1300^{\mathrm{f}}$ & 30 & $\begin{array}{l}0.8[\mathrm{~A}] \\
=\sim 182^{\mathrm{e}}\end{array}$ & 5 & $7^{\mathrm{d}}$ & $\begin{array}{c}\text { BOD }_{\text {particulate }}: \\
51-84 \\
\text { Turbidity: } 49-53 \\
\text { [NTU] } \\
\text { TSS: } 126-160\end{array}$ & $\begin{array}{c}\mathrm{BOD}_{\text {particulate: }} \\
99 \\
\text { Turbidity: } \\
93 \\
\text { TSS: } 95\end{array}$ & n.d. & n.d. & n.d. & n.d. & $\begin{array}{c}\text { Bukhari } 2008 \\
{[106]}\end{array}$ \\
\hline $\begin{array}{c}\text { Underground } \\
\text { water used as } \\
\text { feed water } \\
\text { of a reverse } \\
\text { osmosis (RO) } \\
\text { desalination } \\
\text { plant }\end{array}$ & G & $\begin{array}{c}\text { SS } \\
+ \text { sand } \\
\text { filter }(2 \\
\text { L) \& } \\
\text { Birm iron } \\
\text { filter }\end{array}$ & Batch & $5000^{\mathrm{f}}$ & n.d. & $\begin{array}{l}1^{\mathrm{h}} / 1.75 \\
{[\mathrm{~A}]=} \\
\sim(10- \\
16 / 18- \\
28)^{\mathrm{e}}\end{array}$ & 6 & $7^{\mathrm{d}}$ & $\begin{array}{c}\text { Turbidity: } 150 \\
\text { [NTU] } \\
\text { TSS: } 300 \\
\text { TDS: } 1800\end{array}$ & $\begin{array}{l}\text { Turbidity: } \\
92^{\mathrm{h}} / 98 \\
\text { TSS: } \\
94^{\mathrm{h}} / 99 \\
\text { TDS: } \\
\text { n.d./n.d. }\end{array}$ & n.d. & n.d. & n.d. & n.d. & $\begin{array}{c}\text { Sadeddin } \\
\text { et al. } 2011 \\
{[108]}\end{array}$ \\
\hline $\begin{array}{c}\text { Mineral } \\
\text { treatment } \\
\text { wastewater } \\
\text { containing } \\
\text { ultrafine quartz } \\
\text { suspensions }\end{array}$ & $\mathrm{S}$ & $\mathrm{Al} / \mathrm{SS}$ & Batch & 250 & 21 & $23.9^{\mathrm{g}}$ & 10 & 9 & Turbidity: n.d. & $\begin{array}{l}\text { Turbidity: } \\
\qquad 90^{\mathrm{g}}\end{array}$ & $1.87^{\mathrm{g}}$ & n.d. & n.d. & n.d. & $\begin{array}{c}\text { Kılıç et al. } \\
2009 \\
{[109]}\end{array}$ \\
\hline $\begin{array}{c}\text { Bentonite } \\
\text { suspensions } \\
\text { (representing } \\
\text { clay-polluted } \\
\text { waters) }\end{array}$ & $\mathrm{S}$ & $\mathrm{Fe}$ & Batch & $100^{\mathrm{d}}$ & 30 & 4 & 40 & $(3 / 12)$ & $\begin{array}{c}\text { Turbidity: } 18-24 \\
\text { [NTU] }\end{array}$ & $\begin{array}{l}\text { Turbidity: } \\
85 / 80\end{array}$ & n.d. & n.d. & n.d. & n.d. & $\begin{array}{c}\text { Ghernaout et } \\
\text { al. } 2008 \\
{[110]}\end{array}$ \\
\hline
\end{tabular}

${ }^{\mathrm{a}}=$ HRT (hydraulic retention time) in EC systems with continuous mode of operation [min]; ${ }^{\mathrm{b}}=$ Observed as the best electrode configuration of those tested; ${ }^{\mathrm{c}}=$ The natural, unmodified $\mathrm{pH}$ value of the water or wastewater (found optimal); ${ }^{\mathrm{d}}=$ The natural, unmodified $\mathrm{pH}$ value of the water or wastewater (the effect of $\mathrm{pH}$ not researched); ${ }^{\mathrm{e}}=$ Approximation calculation based on values given in the article at issue; ${ }^{\mathrm{f}}=$ Reactor volume (sample volume not mentioned); ${ }^{\mathrm{g}}=$ Optimum value estimated from the data in the article (precise value not given); ${ }^{\mathrm{h}}=$ Additional "optimum value" estimated from the data in the article; . $\mathrm{d} .=\mathrm{Not}$ determined.

with SS-EC in a batch mode was studied. The wastewater consisted of carrier, brightener, and metal chlorides strongly bound to the organic complexing agent (which comprised $90 \%$ of TOC, total organic carbon). In optimum conditions (see Table 5), complete $\mathrm{Zn}$ and Ni removal was achieved and $66 \%$ of TOC was also removed. 
The natural $\mathrm{pH}$ of the wastewater was found to be optimal. $\mathrm{NaCl}$ additions were also found unnecessary due to the high electrolyte $(1.5-1.7 \mathrm{~g} / 1$ chloride) concentration in the wastewater. EC was concluded to be a promising treatment method for complexed metal removal from wastewater originating in the metal plating industry [90].

Zinc phosphate rinse water (ZPO) from an automotive assembly plant was treated by EC. Use of $\mathrm{Al}$ and $\mathrm{Fe}$ in batch and continuous modes was studied. The removal efficiencies of batch and continuous modes were very similar, thus the values presented in Table 5 are for the batch -Al process only. The removal efficiencies of $\mathrm{Al}$ and $\mathrm{Fe}$ were also very close to each other and no superior electrode material was suggested in the paper. However, Al was chosen as the optimum here because of its slightly better removal efficiencies and economic values. $\mathrm{Al}$ was also found to perform reasonably well in a significantly wider $\mathrm{pH}$ range than Fe. Furthermore, because the optimum initial $\mathrm{pH}$ for $\mathrm{Fe}$ would have been around 3, acid addition would have been necessary (the initial $\mathrm{pH}$ of ZPO was 3.8), whereas Al performed optimally with unmodified $\mathrm{pH}$. In optimum process conditions, EC treatment was able to achieve high removal efficiencies with the pollutant parameters studied (see Table 5) [91].

Treatment of genuine chemical mechanical polishing (CMP) wastewater generated in the semiconductor fabrication industry by a batch -EC system was studied and found applicable. In another study on EC -treatment of CMP wastewater by the same research group, it was observed that $\mathrm{Fe} / \mathrm{Al}$ is the most suitable electrode configuration (out of four different configurations tested) for such wastewater [92]. The CMP wastewater was highly alkaline and turbid (200 - 300 NTU), having a milky appearance while its mean particle size was as minuscule as 85 - $95 \mathrm{~nm}$. Under optimum conditions, the EC process was found to remove $85 \%$ of COD in 20 min with a low EEC -value of $0.64 \mathrm{kWh} / \mathrm{m}^{3}$. The very fast COD removal by the EC process was considered a great advantage of EC. The kinetic data obtained matched the pseudo first-order kinetic model well $\left(\mathrm{R}^{2}=0.97\right)$ [93].

Real carwash wastewater was treated by a combined EC/EO batch process. After Fe-EC, a 90-min EO-step at $100 \mathrm{~A} / \mathrm{m}^{2}$ current density was conducted using a boron-doped diamond (BBD) anode. The removal efficiencies and EEC-values presented in Table $\mathbf{5}$ are in the form $\mathrm{EC} / \mathrm{EC}+\mathrm{EO}$ total; other values are given for the ECstep only. After the EC-step in optimum conditions, $75 \%$ of COD was removed rapidly with low energy consumption $\left(0.14 \mathrm{kWh} / \mathrm{m}^{3}\right)$. Total surfactant removal was also noted after the EC -step. No $\mathrm{pH}$ alterations were found necessary. After the additional EO-step, $97 \%$ of COD was removed with a total EEC-value of 12.0 $\mathrm{kWh} / \mathrm{m}^{3}$. In an earlier study by the same authors, only EO was used to treat the same wastewater, achieving complete COD removal, but at a cost of enormous energy consumption of $375 \mathrm{kWh} / \mathrm{m}^{3}$. Thus, adding EC prior to EO had lowered the EEC -value significantly while achieving similar removal efficiency [94].

High-strength (see Table 5) dark-black-colored biodigester effluent (BDE) from an alcohol distillery was treated by a batch -EC system using iron electrodes, employing RSM to optimize the process. The created model had a high $\mathrm{R}^{2}$ value of 0.8547 and in optimum process conditions, $51 \%$ of COD and $95 \%$ of color were removed. It was also proposed that the EC-sludge of BDE could be used in making blended fuel briquettes along with other organic fuels, as its heating value was found to be 5.3 $\mathrm{MJ} / \mathrm{kg}$ [95].

Variable and highly colored and polluted molasses process water (MPW) from the discharge outlet of an anaerobic/aerobic effluent treatment facility attached to a large industrial fermentation plant was treated by a batch EC system. In this study, $\mathrm{CC}$ using $\mathrm{FeCl}_{3}$ and aluminum sulfate was compared with EC, which was tested with $\mathrm{Al} / \mathrm{SS}$ (found superior) and $\mathrm{Fe} / \mathrm{SS}$ electrode combinations. Both CC processes lowered the $\mathrm{pH}$ of MPW to strongly acidic values of 2.4 and 3.8 , respectively (the natural $\mathrm{pH}$ of MPW was 7.5). However, EC raised the $\mathrm{pH}$ to mildly alkaline $8.6-8.8$, so it was concluded by the authors that this makes EC a significantly better option. Also, at a major industrial plant with a $1000 \mathrm{~m}^{3} / \mathrm{d}$ output, $6 \mathrm{t}$ of coagulant chemical would be needed, whereas only 300 $\mathrm{kg}$ of electrode material would produce similar results. Removal efficiencies were found to be in the same range with CC and EC. The EC process was not optimized properly at all, as the purpose of the work was solely to compare CC and EC. However, the results were still promising (see Table 5) and the reactor used was noticeably larger than in most other studies presented in Tables 1-7 [96].

A study on decolorization of coking wastewater containing inorganic pollutants and organic contaminants by a continuous EC process using $\mathrm{Fe} / \mathrm{Ti}$ electrodes was conducted. The results showed great potential in EC-based decolorization (91\% color removal efficiency) of coking wastewater with only a slight initial $\mathrm{pH}$ alteration from the natural 7 to 8 needed. Adding $\mathrm{NaCl}$ to the water showed a substantial increase in removal efficiency, possibly due to electrogeneration of $\mathrm{Cl}_{2}$, a strong oxidant [97].

An EC technique with aluminum electrodes was used in a batch mode to remove toxic and carcinogenic antimony from antimony mine flotation wastewater. The antimony concentration of the water being treated was 10 $30 \mathrm{mg} / \mathrm{l}$. The water also contained As (10 - $25 \mu \mathrm{g} / \mathrm{l}), \mathrm{SBX}$ (sodium butyl xanthate, $380-430 \mu \mathrm{g} / \mathrm{l}$ ), and substantial amounts of cations; thus no $\mathrm{NaCl}$ was added to increase conductivity. The EC process performed almost as well 
in the initial $\mathrm{pH}$ range of $6-10$ as in the optimal range of $2-6$, indicating a wide scale of applicability and the redundancy of $\mathrm{pH}$ adjustment (the $\mathrm{pH}$ value of raw water was near 7). In optimum conditions (60 min of electrolysis at $166.67 \mathrm{~A} / \mathrm{m}^{2}$ current density), complete As removal and nearly complete antimony removal efficiencies were achieved along with $71 \%$ - 77\% removal efficiency for SBX, indicating that EC is a promising technology for removing antimony from industrial wastewater [98].

Laundry-based wastewater accounts for approximately $10 \%$ of municipal sewer discharges; thus the efficiency of a batch electrochemical system using aluminum electrodes in treating real laundry wastewater (see Table 5 for composition) was investigated [99]. All experiments were repeated twice and the experimental error was below 3\%; average data are reported. The unaltered, nearneutral initial $\mathrm{pH}$ value was found optimal. Removal efficiencies in optimal conditions were high, being $90 \%$ $97 \%$. Therefore, it was concluded that when compared with other treatment processes, EC is more effective in treating laundry wastewater. In another study (not presented in Table 5) on EC treatment of (artificial) laundry wastewater, $62 \%$ COD removal efficiency was reached [100]. In this study, the application of ultrasound was studied and found to clearly enhance the EC process.

The treatability of paint manufacturing wastewater (PMW) by EC in a batch mode was investigated and found economic and feasible. The performance of $\mathrm{Al}$ electrodes was found to be better than that of Fe electrodes in terms of removal efficiency and OC. Initial pollutant concentrations in PMW were very high (COD $19700 \mathrm{mg} / \mathrm{l}$, BOD $2800 \mathrm{mg} / \mathrm{l}, \mathrm{SS} 1100 \mathrm{mg} / \mathrm{l})$, however in optimal process conditions (fast 15 -min treatment at a low current density of $35 \mathrm{~A} / \mathrm{m}^{2}$ ), very high removals of $94 \%$ for COD and $89 \%$ for TOC were achieved. Absorbance decreased substantially as a result of the EC treatment, indicating a significant change in the color of the water. No $\mathrm{pH}$ alteration of the PMW was found necessary [101].

Removal of suspended solids and turbidity from marble processing wastewater by EC was studied using a batch laboratory-scale $(250 \mathrm{ml}$ solution) reactor. Both $\mathrm{Al}$ and $\mathrm{Fe}$ were tested as electrode materials. When iron was used as the electrode material, removal efficiencies were found to be only slightly lower than those of $\mathrm{Al}$, but the $\mathrm{OC}$ values were significantly higher. Therefore, Al (monopolar parallel connection) was chosen as the better option. The initial concentrations of the wastewater were very high (turbidity 2640 FTU, TSS $5178 \mathrm{mg} / \mathrm{l}$ ). EC treatment neutralized the wastewater, slightly lowering its $\mathrm{pH}$ value towards 7 from the initial optimal value of 9 (naturally 8.23). Complete removal of TSS and turbidity was achieved rapidly within $2 \mathrm{~min}$ and even only 0.5 -min EC treatment was able to provide $99 \%$ removal efficien- cies for TSS and turbidity. Therefore, the EEC and OCvalues were very low (see Table 5) and the EC process was concluded to be highly effective in this application [102].

Polyvinyl alcohol (PVA) is a well-known water-solu ble polymer that is hazardous and barely biodegradable. PVA is found in wastewaters of a wide range of industries; thus the feasibility of batch-EC in removing PVA from a synthetic $(100 \mathrm{mg} / \mathrm{l})$ aqueous solution was investigated. Of the four different electrode combinations tested, Fe/Al was found clearly the most efficient. The effect of altering the initial $\mathrm{pH}$ of the PVA solution was not studied. The experimental results showed that the kinetics of PVA removal by EC could be described with a pseudo-second-order model $\left(\mathrm{R}^{2}=0.99\right)$. In optimum conditions, $77 \%$ of the initial PVA was removed [103].

Salicylic acid (SA) is widely used in the pharmaceutical and cosmetic industries and it potentially has adverse health effects in animals and humans. EC -removal of SA $(100 \mathrm{mg} / \mathrm{l})$ from a synthetic industrial aqueous solution using aluminum electrodes in a batch mode was investigated and suggested to be promising. The effect of the initial $\mathrm{pH}$ of the SA solution was not studied and no base $\mathrm{pH}$ value was mentioned. Solution temperature was found to slightly affect removal efficiencies (up to about 9 percentage points in otherwise similar process conditions); $298 \mathrm{~K}$ was found optimal. In optimum conditions (applying a low current density of $12 \mathrm{~A} / \mathrm{m}^{2}$ ), $87 \% \mathrm{SA}$ removal efficiency was documented, also providing an extremely low EEC -value. According to the kinetic data obtained, a pseudo-second-order kinetic model described SA removal best $\left(\mathrm{R}^{2}=0.98\right)$ [104].

The performance of Fe-EC in a batch mode in removing hardness from drinking water was evaluated. The water distribution system water used in this study had a $\mathrm{pH}$ value of 8.35 and total and calcium hardness values of $300 \mathrm{mg} / 1 \mathrm{CaCO}_{3}$ and $138 \mathrm{mg} / 1 \mathrm{CaCO}_{3}$, respectively. In optimum conditions, $98 \%$ of the former and $97 \%$ of the latter were removed, thus it was shown that ions responsible for water hardness could be removed by EC [105].

Raw municipal wastewater was electrocoagulated in a batch mode using SS-electrodes [106]. The EC-treatment was found effective and rapid, as it took only $5 \mathrm{~min}$ to achieve $99 \%, 93 \%$, and $95 \%$ removal efficiencies for $\mathrm{BOD}_{\text {particulate, }}$ turbidity, and TSS, respectively. EC test runs were conducted using only raw wastewater with a $\mathrm{pH}$ of 7. In another study (not presented in Table 5) on actual municipal wastewater, it was concluded that by using very low currents $\left(10 \mathrm{~A} / \mathrm{m}^{2}\right)$, EC can reduce phosphorus and pollution associated with colloids, helping to diminish the organic load of the effluent [107].

Underground water (containing colloidal particles which cause membrane fouling in reverse osmosis, RO) used as the feed water of a RO desalination plant was 
treated with a batch EC-system using electrodes made of SS. A sand filter (2 l) also containing a Birm (a solid similar to active carbon, used for iron removal) filter was added to the process line after the EC unit to remove coagulated matter. The removal efficiencies given in Table 5 were achieved after the whole process. Before EC, the water had turbidity and TSS values of 150 NTU and 300 $\mathrm{mg} / \mathrm{l}$, respectively, and its $\mathrm{pH}$ was 7.0. Experiments were conducted using this initial $\mathrm{pH}$ only. For both parameters, very high removal efficiencies were achieved rapidly (6 min) and with low current values. Further RO studies conducted using EC-pretreated water proved that all fouling indicators such as flow, pressure drop, and silt density index (SDI) showed less fouling when EC was added prior to EO [108].

Mineral treatment processes produce wastewater containing suspended and stable colloidal particles which degrade recirculation of water in processing plants. Such synthetic aqueous solutions containing quartz were treated by batch-EC using Al/SS electrodes. The median particle size of the quartz-in-water $(320 \mathrm{mg} / \mathrm{l}$ quartz, initial $\mathrm{pH} 4$ ) was $11.61 \mu \mathrm{m}$. A comparison between EC and $\mathrm{CC}$ (using aluminum sulfate in jar tests) was made, achieving similar removal efficiencies (around 90\%) when similar amounts of aluminum were added to the water. The optimum $\mathrm{pH}$ range of $\mathrm{CC}$ was found to be 6 9, which was wider than that of EC. However, CC was found to acidify the water, whereas EC treatment shifted the initial suspension $\mathrm{pH}$ towards neutral. A 10-min treatment was sufficient for both methods and the kinetics of EC could be modeled with a second-order rate equation. No clearly superior treatment method for the wastewater in question could be proposed within the scope of the study, as no economic values were presented [109].

In another study, EC-treatment of synthetic wastewater was carried out in a batch electrochemical cell equipped with iron electrodes. Bentonite suspensions $(\sim 20$ NTU turbidity) represented colloid-polluted wastes, as clays behave like hydrophobic colloids in water. Turbidity removals of $80 \%-85 \%$ could be obtained with very low currents $\left(4 \mathrm{~A} / \mathrm{m}^{2}, 40\right.$-min EC-run). The effect of initial $\mathrm{pH}$ was explored with values of 3,7 , and 12 , and only the neutral initial $\mathrm{pH}$ gave poor results. This was explained as being due to different destabilization mechanisms being prevalent in medias of different $\mathrm{pH}$ values. In acidic media, charge neutralization was considered to be the main removal mechanism, whereas sweep flocculation would be dominant in an alkaline solution of this type. It was concluded that the EC process can be applied to treatment of wastes polluted with colloids [110].

\subsection{Surface Water and Other Natural Water}

Table 6 presents a summary of recent applications of EC in the treatment of surface water and other natural water.

Treating simulated surface water containing algae (one of the most dominant cyanobacteria, Microcystis aeruginosa) by batch -EC was studied. The initial cell density used in the experiments was maintained at $1.2 \times 10^{9}-1.4$ $\times 10^{9}$ cells $/$. Aluminum was found to be an excellent electrode material for this application compared with iron (no coloration of water and substantially greater removal efficiency). Interestingly, it was found that algae removal was accelerated dramatically with increased water temperature. Ultimately, complete algae removal was achieved with low values of current density and EEC: 10 $\mathrm{A} / \mathrm{m}^{2}$ and $0.4 \mathrm{kWh} / \mathrm{m}^{3}$, respectively. Thus, the results were proposed to indicate the effectiveness of EC in algae removal, from both the technical and economic points of view [111].

Laboratory experiments were carried out to investigate the effectiveness of disinfection by EC in a batch mode using artificial wastewater containing Escherichia coli. Real north-Algerian dam water from Ghrib (known for having high hardness) and Keddara (high algae content) dams were also used. The EC parameters presented for the three waters in Table 6 are in the same order as mentioned above. Aluminum electrodes were found slightly more efficient than ordinary steel $(\mathrm{Fe})$ and stainless steel electrodes. Electrochemical disinfection was proven effective, because the treatment times were rather low and total disinfection and algae removal were achieved [112].

In another study (not presented in Table 6), Al -EC in a batch mode was found to be a suitable process for decreasing hardness and removing bacteria, algae, and bacterial nutriments from two different raw surface waters. The water samples originated from a river and a pond. Complete disinfection was achieved [113].

Reduction of humic acids (HA) from $1000 \mathrm{mg} / 1 \mathrm{syn}-$ thetic solutions by a batch Al-EC system was studied [114]. The effect of applying electromagnetic (EM) treatment prior to EC was also investigated in both batch and continuous modes, of which the latter was found more suitable. EM is an attractively simple approach in which the water being treated flows through a magnetic field, and it consequently slightly changes some of its physicochemical properties. Both EM and EC processes were found to perform best at neutral $\mathrm{pH}$. The 10-min EM-pretreatment was found to slightly further increase the removal efficiency of HA by EC from $96 \%$ to $100 \%$ [114].

Removal of NOM (natural organic matter) from surface water (inlet flow of a Finnish paper mill) by a batch EC process using aluminum electrodes has been studied using RSM and ANOVA. In modeled optimum conditions, the applied current density, treatment time, and EEC-value were low, with simultaneous high removal efficiency. A slight lowering of initial $\mathrm{pH}$ (naturally 5.8) 
Table 6. Recent applications of EC in the treatment of surface water and other natural water.

\begin{tabular}{|c|c|c|c|c|c|c|c|c|c|c|c|c|c|c|c|}
\hline $\begin{array}{l}\text { Water and } \\
\text { wastewater } \\
\text { types used }\end{array}$ & $\begin{array}{l}\text { Genuine } \\
\text { (G)/ } \\
\text { Synthetic } \\
\text { (S) water }\end{array}$ & $\begin{array}{l}\text { Anode/ } \\
\text { cathode } \\
\text { material }\end{array}$ & $\begin{array}{c}\text { Reactor } \\
\text { type }\end{array}$ & $\begin{array}{c}\text { Volume } \\
\text { treated } \\
{[\mathrm{ml}]}\end{array}$ & $\begin{array}{l}\text { Optimum } \\
\text { electrode } \\
\text { gap [mm] }\end{array}$ & $\begin{array}{l}\text { Optim } \\
\text { density } \\
\text { time an } \\
{\left[\mathrm{A} / \mathrm{m}^{2}\right.}\end{array}$ & $\begin{array}{l}\text { num cur } \\
\text { y, treatn } \\
\text { nd initia } \\
\left.{ }^{2}\right],[\mathrm{min}]\end{array}$ & $\begin{array}{l}\text { rent } \\
\text { ment } \\
\text { al pH } \\
\text { ], [] }\end{array}$ & $\begin{array}{c}\text { Initial } \\
\text { pollutant } \\
\text { levels } \\
{[\mathrm{mg} / \mathrm{l}]}\end{array}$ & $\begin{array}{c}\text { Optimum } \\
\text { removal } \\
\text { efficiency } \\
{[\%]}\end{array}$ & $\begin{array}{l}\text { Optimum } \\
\text { EEC } \\
{\left[\mathrm{kWh} / \mathrm{m}^{3}\right]}\end{array}$ & $\begin{array}{c}\text { Optimum } \\
\text { EEC } \\
{\left[\mathrm{kWh} / \mathrm{kg}_{\mathrm{x}}\right]}\end{array}$ & $\begin{array}{c}\text { Optimum } \\
\text { OC } \\
{\left[€ / \mathrm{m}^{3}\right]}\end{array}$ & $\begin{array}{l}\text { Optimum } \\
\text { OC } \\
{\left[€ / \mathrm{kg}_{\mathrm{X}}\right]}\end{array}$ & $\begin{array}{l}\text { Research } \\
\text { group }\end{array}$ \\
\hline $\begin{array}{c}\text { Water } \\
\text { containing } \\
\text { algae } \\
\text { (cyanobacteria) }\end{array}$ & $\mathrm{S}$ & $\begin{array}{c}\mathrm{Al}^{\mathrm{b}} \\
\mathrm{Fe}\end{array}$ & Batch & 1000 & 10 & 10 & 45 & $4-7$ & $\begin{array}{c}\text { Cyanobacteria: } \\
1.2 \times 10^{9}- \\
1.4 \times 10^{9} \\
{[\text { cells } / 1]}\end{array}$ & $\begin{array}{c}\text { Cyanobacteria: } \\
100\end{array}$ & 0.4 & n.d. & n.d. & n.d. & $\begin{array}{c}\text { Gao et al. } \\
2010 \\
{[111]}\end{array}$ \\
\hline Dam waters & $\mathrm{S}+\mathrm{G} \times 2$ & $\begin{array}{c}\mathrm{Al}^{\mathrm{b}} \\
\text { Steel } \\
\mathrm{SS}\end{array}$ & Batch & 500 & 50 & $\begin{array}{c}\left(1^{\mathrm{g}} / 0.8 / 0 .\right. \\
25)[\mathrm{A}] \\
= \\
\sim(202 / 16 \\
2 / 51)^{\mathrm{e}}\end{array}$ & $\begin{array}{c}10^{\mathrm{g} /} \\
35 / \\
30\end{array}$ & $\begin{array}{l}7- \\
9.5\end{array}$ & $\begin{array}{l}\text { E. coli: } \\
\text { n.d./n.d./ } \\
\text { n.d. }\end{array}$ & $\begin{array}{c}\text { E. coli: } \\
98^{\mathrm{g}} / 100 / 100\end{array}$ & $\begin{array}{c}\sim 23.6^{\mathrm{e}} / 16.8 \\
\quad / \sim 4.7^{\mathrm{e}}\end{array}$ & n.d. & n.d. & n.d. & $\begin{array}{c}\text { Ghernaout } \\
\text { et al. 2008 } \\
{[112]}\end{array}$ \\
\hline $\begin{array}{l}\text { Water contain- } \\
\text { ing humic acids } \\
\text { (HA) }\end{array}$ & $\mathrm{S}$ & $\mathrm{Al}$ & $\begin{array}{c}\text { Batch } \\
\text { Continuous } \\
\text { (EM) }+ \\
\text { Batch } \\
\text { (EC) }\end{array}$ & 500 & 40 & 33.3 & $\begin{array}{c}30 \\
10^{\mathrm{a}} \\
(0.01 \\
1 / \mathrm{min}) \\
+30\end{array}$ & $\begin{array}{c}7 \\
7+7\end{array}$ & HA: 1000 & $\begin{array}{r}\text { HA: } 96 \\
100\end{array}$ & n.d. & n.d. & n.d. & n.d. & $\begin{array}{c}\text { Ghernaout } \\
\text { et al. } 2009 \\
{[114]}\end{array}$ \\
\hline $\begin{array}{c}\text { Surface water } \\
\text { (river) } \\
\text { containing a } \\
\text { high } \\
\text { concentration } \\
\text { of NOM } \\
\text { (paper mill } \\
\text { inlet flow) }\end{array}$ & G & $\mathrm{Al}$ & Batch & $500^{\mathrm{i}}$ & $10^{\mathrm{i}}$ & 4.8 & $12^{\mathrm{i}}$ & 4.3 & $\begin{array}{c}\text { DOC: } 18.35 \\
\text { UV } 254 \mathrm{~nm}: \\
0.64 \text { [ab- } \\
\text { sorbance] } \\
\text { Turbidity: } \\
0.51 \text { [NTU] }\end{array}$ & $\begin{array}{c}\text { DOC: } 80 \\
\text { UV }_{254:} 91 \\
\text { Turbidity: } \\
\text { n.d. }\end{array}$ & 0.4 & n.d. & n.d. & n.d. & $\begin{array}{c}\text { Vepsäläinen } \\
\text { et al. 2009 } \\
{[115]}\end{array}$ \\
\hline $\begin{array}{l}\text { Micro-polluted } \\
\text { raw water }\end{array}$ & G & $\begin{array}{c}\mathrm{Al}^{\mathrm{b}} \\
\mathrm{Fe}\end{array}$ & Batch & 1000 & 10 & 50 & 20 & $\begin{array}{c}5- \\
7.5 \\
{\left[7.5^{\mathrm{c}}\right]}\end{array}$ & $\begin{array}{c}\text { TOC: } \\
8.5-16.2 \\
\text { Oil: } 0.8-1.5 \\
\mathrm{NH}_{3}-\mathrm{N}: \\
0.75-1.26\end{array}$ & $\begin{array}{c}\text { TOC: } 70 \\
\text { Oil: } 86 \\
\mathrm{NH}_{3}-\mathrm{N}: 75\end{array}$ & n.d. & n.d. & n.d. & n.d. & $\begin{array}{c}\text { Li et al. } \\
2008 \\
{[116]}\end{array}$ \\
\hline $\begin{array}{l}\text { Marine water } \\
\text { containing } \\
\text { microalgae (for } \\
\text { biodiesel } \\
\text { production) }\end{array}$ & $\mathrm{S} \times 2$ & SS & Batch & 300 & 48 & $\begin{array}{c}10 \\
{[\mathrm{~V}]}\end{array}$ & 15 & $4-9$ & $\begin{array}{c}\text { Microalgal: } \\
600 / 300\end{array}$ & $\begin{array}{c}\text { Microalgal: } \\
98 / 99\end{array}$ & n.d. & $\begin{array}{c}4.44 / 9.16 \\
\mathrm{kWh} / \\
\mathrm{kg}_{\text {Microalgal }}\end{array}$ & n.d. & n.d. & $\begin{array}{c}\text { Uduman } \\
\text { et al. } 2011 \\
{[117]}\end{array}$ \\
\hline $\begin{array}{l}\text { Freshwater and } \\
\text { marine water } \\
\text { containing } \\
\text { microalgae (for } \\
\text { biodiesel } \\
\text { production) }\end{array}$ & $\mathrm{S} \times 2$ & $\begin{array}{c}\mathrm{Al} /\left(\mathrm{IrO}_{2} /\right. \\
\left.\mathrm{TiO}_{2}\right)^{\mathrm{b}} \\
\mathrm{Fe} /\left(\mathrm{IrO}_{2} /\right. \\
\left.\mathrm{TiO}_{2}\right)\end{array}$ & Batch & 1000 & 44 & $(6 / 15)^{\mathrm{g}}$ & $\begin{array}{l}(30 / \\
50)^{\mathrm{g}}\end{array}$ & $\begin{array}{c}4-6 \\
{[4]}\end{array}$ & $\begin{array}{c}\text { Microalgal: } \\
300-600 / \\
300-600\end{array}$ & $\begin{array}{c}\text { Microalgal: } \\
(80 / 95)^{\mathrm{g}}\end{array}$ & n.d. & $\begin{array}{c}\sim 0.3 / \\
\sim(1.5-2.0) \\
\mathrm{kWh} / \\
\mathrm{kg}_{\text {Microalgal }}\end{array}$ & n.d. & n.d. & $\begin{array}{c}\text { Vandamme } \\
\text { et al. } 2011 \\
{[118]}\end{array}$ \\
\hline $\begin{array}{l}\text { Pesticide- } \\
\text { contaminated } \\
\text { (metribuzin, } \\
\text { MB) ground- } \\
\text { water }\end{array}$ & $\mathrm{S}$ & $\mathrm{Fe} / \mathrm{SS}$ & $\begin{array}{c}\text { Batch } \\
\text { Batch }+ \\
\text { UV }\end{array}$ & $1300^{\mathrm{f}}$ & n.d. & 18 & 80 & $\begin{array}{l}5-6 \\
{\left[6^{c}\right]} \\
6-7 \\
{\left[6^{c}\right]}\end{array}$ & $\begin{array}{c}\text { MB: } 50-300 \\
\text { (optimum } \\
200)\end{array}$ & $\begin{array}{r}\text { MB: } 89 \\
95\end{array}$ & n.d. & n.d. & n.d. & n.d. & $\begin{array}{c}\text { Yahiaoui } \\
\text { et al. 2011 } \\
{[119]}\end{array}$ \\
\hline $\begin{array}{l}\text { Geothermal } \\
\text { waters } \\
\text { containing } \\
\text { boron }\end{array}$ & $\mathrm{G}$ & $\mathrm{Al}$ & Batch & 1500 & 5 & $\begin{array}{c}15^{\mathrm{h}} / \\
30^{\mathrm{h}} / \\
60\end{array}$ & 30 & 8 & B: 24 & $\begin{array}{c}\text { B: } \\
73^{\mathrm{h}} / 84^{\mathrm{h}} / 96\end{array}$ & $\begin{array}{c}0.73^{\mathrm{h}} / \sim 2.3^{\mathrm{h}} \\
\quad / 12.8\end{array}$ & n.d. & n.d. & n.d. & $\begin{array}{c}\text { Yilmaz } \\
\text { et al. 2008 } \\
{[120]}\end{array}$ \\
\hline $\begin{array}{l}\text { Riverwater } \\
\text { containing } \\
\text { mercury(II) }\end{array}$ & $\mathrm{S} \times 2$ & $\begin{array}{c}\mathrm{Al} \\
\mathrm{Fe}^{\mathrm{b}}\end{array}$ & Batch & 100 & 30 & 125 & 15 & $\begin{array}{c}3-7 \\
{[7]}\end{array}$ & $\begin{array}{c}\mathrm{Hg}^{2+}: 4 \\
\mathrm{Hg}^{2+}: 4 \\
\text { COD: } 378\end{array}$ & $\begin{array}{c}\mathrm{Hg}^{2+}: 100 \\
\mathrm{Hg}^{2+}: 100 \\
\text { COD: } 90\end{array}$ & n.d. & n.d. & n.d. & n.d. & $\begin{array}{l}\text { Nanseu- } \\
\text { Njiki } \\
\text { et al. } 2009 \\
{[121]}\end{array}$ \\
\hline
\end{tabular}

${ }^{\mathrm{a}}=$ HRT (hydraulic retention time) in EC systems with continuous mode of operation [min]; ${ }^{\mathrm{b}}=$ Observed as the best electrode configuration of those tested; ${ }^{\mathrm{c}}=$ The natural, unmodified $\mathrm{pH}$ value of the water or wastewater (found optimal); ${ }^{\mathrm{e}}=$ Approximation calculation based on values given in the article at issue; ${ }^{\mathrm{f}}=$ Reactor volume (sample volume not mentioned); ${ }^{\mathrm{g}}=$ Optimum value estimated from the data in the article (precise value not given); ${ }^{\mathrm{h}}=$ Additional "optimum value" estimated from the data in the article; ${ }^{i}=$ Queried from the author; n.d. = Not determined.

was found beneficial. The above values are presented in Table 6 for water at room temperature $\left(23^{\circ} \mathrm{C}\right)$. The water samples taken from the river were at $3^{\circ} \mathrm{C}$ and $\mathrm{EC}$-runs were also performed with water of this temperature. The removal efficiency was then only four percentage points lower, thus it was concluded that EC is a feasible treatment process for removal of NOM also during the cold water period in the Nordic countries [115].

Batch-EC was used and found feasible for treating micro-polluted surface water in laboratory-scale experiments. Aluminum was selected as the electrode material, because although iron produced nearly similar removal efficiencies, it also colored the water (to greenish at first and then to brown). Initial pollutant concentrations were 
very low (see Table 6), but so were also the optimal current density and treatment times $\left(50 \mathrm{~A} / \mathrm{m}^{2}\right.$ and $20 \mathrm{~min}$, respectively). Also, no $\mathrm{pH}$ adjustment was found necessary [116].

Chlorococcum sp. and Tetraselmis sp. (results in this order in Table 6) were cultivated to produce artificial marine water to be separated by batch-EC from microalgae for use in biodiesel production. Both species were quite different but had approximate cell sizes of $10 \mu \mathrm{m}$. Altering the initial $\mathrm{pH}$ value between 4 - 9 had no clear impact on removal efficiencies; EC was found applicable over the whole scale tested. Both waters were naturally within this $\mathrm{pH}$ range: the first water had a $\mathrm{pH}$ value of 9.1 and the latter, 8.3. High recovery efficiencies were obtained, up to $98 \%$ and $99 \%$ for Chlorococcum sp. and Tetraselmis sp., respectively. Microalgae flotation due to hydrogen bubble attachment was documented using a hi-speed camera; this is presented in Figure 6 [117].

In another similar study, using EC to harvest synthetic marine water (containing Phaeodactylum tricornutum) and freshwater (containing Chlorella vulgaris) for biodiesel production was evaluated (results in this order in Table 6). Using $\mathrm{Al}$ as anodes was found clearly more efficient than using Fe. Both electrode configurations had cathodes made of $\mathrm{IrO}_{2} / \mathrm{TiO}_{2}$, which is fairly uncommon. The aluminum content of the harvested microalgal biomass was less than $1 \%$, while the aluminum concentration of the process water was below $2 \mathrm{mg} / \mathrm{L}$ for C. Vulgaris and below $0.5 \mathrm{mg} / \mathrm{l}$ for $P$. tricornutum. Rather rarely, the effect of stirring the water was tested, within a range of $0-200 \mathrm{rpm}$. It was found that increasing the stirring speed significantly increased the performance of the EC process up to a value of $150 \mathrm{rpm}$, enhancing contact rates between coagulants and microalgal cells. However, further increasing the stirring rate was found to decrease the performance of the EC process to near the level of $0 \mathrm{rpm}$. This was proposed to be due to the break-up of flocs because of the high shear forces applied. Under optimal conditions, the EEC-values were around $0.3 \mathrm{kWh} / \mathrm{kg}_{\text {algae }}$ harvested for $P$. tricornutum and approximately $1.5-2.0 \mathrm{kWh} / \mathrm{kg}_{\text {algae }}$ for $C$. vulgaris, while the respective microalgal recovery rates were $80 \%$ and $95 \%$. In specific triplication tests, the process was found to be repeatable. Compared to centrifugation, EC was thus suggested as substantially more energy-efficient. Finally, it was concluded that EC is a promising technology for harvesting marine microalgae, but tests with large-scale pilot EC reactors need to be done to confirm this [118].

A batch EC system using a Fe/SS electrode configuration was used to treat model pesticide-contaminated (metribuzin, MB) groundwater. Metribuzin is considered a general-use pesticide which belongs to the group of triazinone herbicides, and it is highly water-soluble (1.05 $\mathrm{g} / \mathrm{l})$. The initial MB values used in the study (50 - 300 $\mathrm{mg} / \mathrm{l})$ were similar to those measured in discharges from MB manufacturers. The performance of the EC process was compared with that of a batch combined EC $+\mathrm{UV}$ (ultraviolet) process, and the latter was found slightly more effective (MB removal efficiencies of $89 \%$ and $95 \%$, respectively). Using a batch $\mathrm{EF}+\mathrm{UV}$ process to treat the water was also investigated, but it resulted in lower removal efficiencies than the EC + UV process, and thus the results are not shown in Table 6. When the water was treated with UV alone for $80 \mathrm{~min}$ (optimal value found for EC $+\mathrm{UV}$ ), approximately $12 \%$ removal efficiencies were achieved (see Figure 6 in the original paper). The natural initial $\mathrm{pH}$ value (6) of the water was found optimal for both the EC and EC + UV processes, while low $\mathrm{pH}$ values would have been needed for optimal functioning of the EF + UV process. In the end, it was proposed that the process studied may be employed successfully to remove pesticides from water [119].

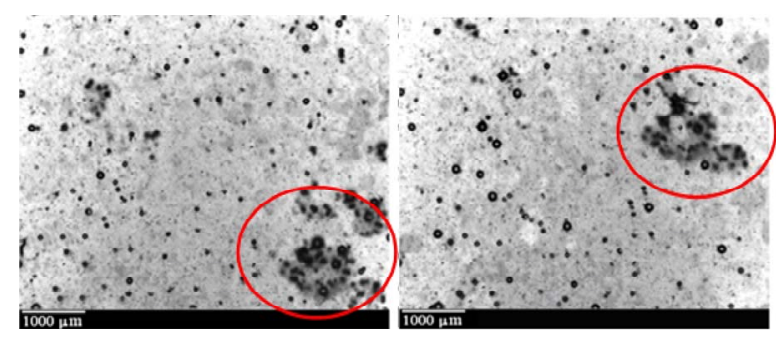

(a)

(b)

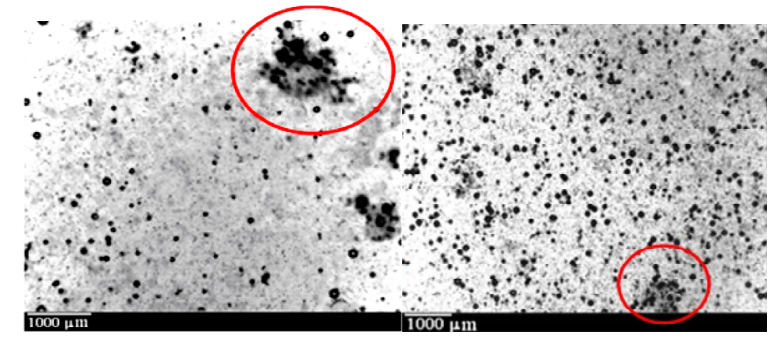

(c)

(d)

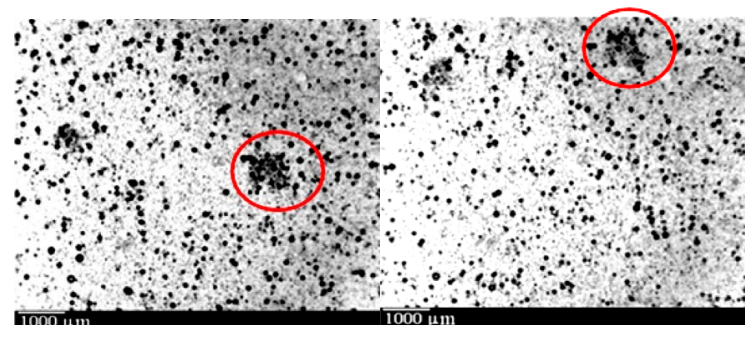

(e)

(f)

Figure 6. Hydrogen bubble-floc interaction at different times: For Chlorococcum sp.: (a) $0 \mathrm{~s}$; (b) $0.4 \mathrm{~s}$; and (c) $0.8 \mathrm{~s}$ after the current was turned off. For Tetraselmis sp.; (d) 0.4 $\mathrm{s}$; (e) $0.7 \mathrm{~s}$; and (f) $0.8 \mathrm{~s}$ after the current was turned off. (Main bubble-microalgae floc aggregates are circled in each figure). Adapted from [117]. 
Although boron is a vital micronutrient for plant and crop growth, high boron concentrations in irrigation water are known to be detrimental to them. Therefore, treatment of genuine geothermal water containing $24 \mathrm{mg} / \mathrm{l}$ boron was studied with an EC system working in a batch mode and using aluminum electrodes. An initial $\mathrm{pH}$ value of 8 was found optimal, which was near to the natural value of 6.5 . It was found that decreasing the current density value from $60 \mathrm{~A} / \mathrm{m}^{2}$ (proposed as optimal) to $30 \mathrm{~A} / \mathrm{m}^{2}$ or 15 $\mathrm{A} / \mathrm{m}^{2}$ corresponds to a tremendous decrease in the EECvalue from $12.8 \mathrm{kWh} / \mathrm{m}^{3}$ to $2.3 \mathrm{kWh} / \mathrm{m}^{3}$ and 0.73 $\mathrm{kWh} / \mathrm{m}^{3}$, respectively, while boron removal efficiencies decreased from $96 \%$ to $84 \%$ and $73 \%$, respectively. It was concluded that after the EC process, the effluent water could be used for irrigation [120].

Studies on mercury (II) removal from water were conducted using a laboratory-scale $(100 \mathrm{ml})$ batch-EC system. A synthetic mercury-containing (4 mg/l) solution was first used to optimize the process. Iron was found to perform better than aluminum; however, both electrodes achieved very high removal efficiencies over a wide $\mathrm{pH}$ scale. Mercury was then added to a river water sample achieved very high removal efficiencies over a wide $\mathrm{pH}$ scale. Mercury was then added to a river water sample and the solution was treated in the previously determined optimum process conditions (see Table 6). Complete mercury removal was achieved also from the semi-synthetic mercury-contaminated river water, with 90\% COD removal, as well. It was concluded that EC can be effective in the treatment of water polluted by mercury(II) ions [121].

\subsection{Model Water and Wastewater Containing Heavy Metals, Nutrients, Cyanide and Other Elements and Ions}

EC studies presented in this category of waters can be simplified to have been conducted using small-scale laboratory $\mathrm{Al}, \mathrm{Fe}$, or $\mathrm{SS}$ batch reactors and synthetic model water or wastewater with only one particular pollutant removed (see Table 7). Therefore, not all of the studies [13,122-137] are discussed in the following text (although the optimum conditions found are presented in Table 7), but only those which differ notably from this in some way. Table 7 presents a summary of recent applications of EC in the treatment of waters containing heavy metals, cyanide, and other elements and ions.

Arsenic removal batch-EC experiments using iron were conducted in a laboratory with synthetic solutions, providing complete $\mathrm{As}(\mathrm{V})$ removal with a short treatment time. The experiments were further expanded to field tests in which 50-1 batches of real arsenic- and phosphate-containing groundwater were treated. In the field tests, a filtration step was also added after the EC, raising the removal efficiency of total arsenic from $97 \%$ to $100 \%$.
The economic values were found to be very low and the naturally neutral initial $\mathrm{pH}$ of the water was found optimal [122].

Iron-containing $(25 \mathrm{mg} / \mathrm{l})$ synthetic solutions were treated by batch-EC. Magnesium was used as the anode material (iron as the cathode), which is rare, but the EC system performed well and in optimum conditions very high removal efficiencies with very low current density values were achieved (see Table 7) [123].

Magnesium was used as the anode material (with a SS cathode) in yet another study. The synthetic water being treated contained boron and the batch EC system performed well in removing it. A scale-up batch EC system with an 8.5-1 cell volume was also built and tested. It was found to produce exactly similar removal efficiencies with similar (optimum) process conditions ( $86 \%$ of initial boron removed at an initial $\mathrm{pH}$ of 7 , using a low current density of $20 \mathrm{~A} / \mathrm{m}^{2}$ ). This was concluded to show the robustness of the EC process [125].

Removal of cadmium from aqueous solutions was studied with Al-EC in a batch mode. In addition to using a regular DC power source, application of an alternating pulse current (APC) to prevent passivation of the electrodes was studied. EC in the APC mode was found to perform slightly better than in the DC mode, with nearcomplete cadmium removal and a significantly shorter treatment time required. Also, a pilot-scale batch-EC system with a 2000-1 cell volume was built and tested in this study. The results were consistent with the results obtained from the laboratory scale, showing that the process was technologically feasible and scalable. Adding high concentrations of co-existing ions (carbonate, phosphate, silicate, or arsenate) to the solution was found to decrease cadmium removal efficiency significantly due to competition for adsorption binding sites [126].

Removal of chromium from synthetic solutions with concentrations of 50,100,500, and $1000 \mathrm{mg} / 1$ (values given in this order in Table 7) were treated with a batchEC system using aluminium/iron electrodes. Use of APC was also studied in addition to the DC mode. During these experiments the polarity of the anode and cathode was thus changed every $4 \mathrm{~min}$. It was found that the APC mode was more efficient than the DC mode here, also, with operating times $3 \%, 6 \%, 15 \%$, and $25 \%$ shorter when treating initial $\mathrm{Cr}(\mathrm{VI})$ concentrations of 50, 100 , 500 , and $1000 \mathrm{mg} / \mathrm{l}$, respectively. This makes the APC mode more cost-effective. Also, the turbidity values of the treated water were $1 \mathrm{NTU}$ and $20 \mathrm{NTU}$ with APC and DC, respectively. $\mathrm{NaCl}, \mathrm{KCl}, \mathrm{PAC}$, and $\mathrm{NaNO}_{3}$ were tested as a supporting electrolyte; $\mathrm{NaCl}$ and $\mathrm{KCl}$ were found most suitable in every aspect. In optimum conditions, complete removal of chromium was achieved [127].

Solutions containing radioactive strontium were treated with a batch-EC system. Initial concentrations of 
Table 7. Recent applications of EC in the treatment of waters containing heavy metals, cyanide, and other elements and ions.

\begin{tabular}{|c|c|c|c|c|c|c|c|c|c|c|c|c|c|c|c|}
\hline $\begin{array}{l}\text { Water and } \\
\text { wastewater } \\
\text { types used }\end{array}$ & $\begin{array}{l}\text { Genuine } \\
\text { (G)/ } \\
\text { Synthetic } \\
\text { (S) water }\end{array}$ & $\begin{array}{l}\text { Anode/ } \\
\text { cathode } \\
\text { material }\end{array}$ & $\begin{array}{l}\text { Reactor } \\
\text { type }\end{array}$ & $\begin{array}{c}\text { Volume } \\
\text { treated } \\
{[\mathrm{ml}]}\end{array}$ & $\begin{array}{l}\text { Optimum } \\
\text { electrode } \\
\text { gap }[\mathrm{mm}]\end{array}$ & $\begin{array}{r}\text { Optir } \\
\text { densi } \\
\text { time a } \\
{[\mathrm{A} / \mathrm{m}}\end{array}$ & $\begin{array}{l}\text { imum cur } \\
\text { ity, treatn } \\
\text { and initia } \\
\left.\mathrm{m}^{2}\right] \text {, [min }\end{array}$ & $\begin{array}{l}\text { rent } \\
\text { nent } \\
\text { l pH } \\
],[]\end{array}$ & $\begin{array}{c}\text { Initial } \\
\text { pollutant } \\
\text { levels } \\
{[\mathrm{mg} / \mathrm{l}]}\end{array}$ & $\begin{array}{c}\text { Optimum } \\
\text { removal } \\
\text { efficiency } \\
{[\%]}\end{array}$ & $\begin{array}{l}\text { Optimum } \\
\text { EEC } \\
{\left[\mathrm{kWh} / \mathrm{m}^{3}\right]}\end{array}$ & $\begin{array}{l}\text { EEC } \\
{\left[\mathrm{kWh} / \mathrm{kg}_{\mathrm{x}}\right]}\end{array}$ & $\begin{array}{c}\text { Optimum } \\
\text { OC } \\
{\left[€ / \mathrm{m}^{3}\right]}\end{array}$ & $\begin{array}{c}\text { Optimum } \\
\text { OC } \\
{\left[€ / \mathrm{kg}_{\mathrm{X}}\right]}\end{array}$ & $\begin{array}{l}\text { Research } \\
\text { group }\end{array}$ \\
\hline $\begin{array}{l}\text { Contaminated } \\
\text { groundwater } \\
\text { (As) }\end{array}$ & $\mathrm{S}$ & $\begin{array}{c}\mathrm{Al} \\
\mathrm{Fe}^{\mathrm{b}}\end{array}$ & Batch & 650 & 13 & 2.5 & 2.5 & $\begin{array}{c}5.5- \\
7.5 \\
{[6.5]}\end{array}$ & As: 0.15 & As: 99 & 0.014 & n.d. & 0.0047 & n.d. & $\begin{array}{c}\text { Kobya et al. } \\
2011 \\
{[13]}\end{array}$ \\
\hline $\begin{array}{l}\text { Contaminated } \\
\text { drinking water } \\
\text { (As) }\end{array}$ & $\begin{array}{l}S \\
\text { G }\end{array}$ & $\mathrm{Fe}$ & $\begin{array}{c}\text { Batch } \\
\text { Batch } \\
\text { (scale-up/ } \\
\text { field test) }\end{array}$ & $\begin{array}{c}1000 \\
50000\end{array}$ & $\begin{array}{c}20 \\
5\end{array}$ & $\begin{array}{c}0.022 \\
{[\mathrm{~A}]=} \\
3.9^{\mathrm{e}} \\
2[\mathrm{~A}]\end{array}$ & $\begin{array}{c}(5 / 15)^{\mathrm{g}} \\
180\end{array}$ & $\begin{array}{l}5-7 \\
{\left[7^{c}\right]}\end{array}$ & $\begin{array}{c}\mathrm{As}(\mathrm{V}): \\
0.1-1.0 \\
\mathrm{As}_{\text {total }} \\
0.45-0.67 \\
\text { Phosphate: } \\
0.18-0.75\end{array}$ & $\begin{array}{c}\text { As }(V): \\
(\sim 97 / 100)^{\mathrm{g}} \\
\text { As }_{\text {total }}: 100 \\
\text { Phosphate: } \\
100\end{array}$ & $\begin{array}{c}0.5 \\
0.72- \\
0.78\end{array}$ & n.d. & $\begin{array}{l}\text { n.d. } \\
0.077\end{array}$ & n.d. & $\begin{array}{c}\text { Wan et al. } \\
2011 \\
{[122]}\end{array}$ \\
\hline $\begin{array}{l}\text { Contaminated } \\
\text { drinking water } \\
(\mathrm{Fe})\end{array}$ & $\mathrm{S}$ & $\mathrm{Mg} / \mathrm{Fe}$ & Batch & 900 & 5 & $2^{\mathrm{h}} / 6$ & 35 & 6 & $\begin{array}{c}\text { Fe: } 5-25 \\
\text { (optimum } \\
25)\end{array}$ & Fe: $92^{\mathrm{h}} / 98$ & n.d. & n.d. & n.d. & n.d. & $\begin{array}{c}\text { Vasudevan } \\
\text { et al. 2009 } \\
{[123]}\end{array}$ \\
\hline $\begin{array}{l}\text { Contaminated } \\
\text { drinking water } \\
(\mathrm{Fe})\end{array}$ & $\mathrm{S}$ & $\mathrm{Al}$ & Batch & 1000 & 5 & 12.5 & 40 & 8 & $\begin{array}{c}\text { Fe: } 2-15 \\
\text { (optimum } \\
10)\end{array}$ & Fe: 99 & $\sim 9.4^{\mathrm{g}}$ & n.d. & 0.21 & n.d. & $\begin{array}{c}\text { Ghosh et al. } \\
2010 \\
{[124]}\end{array}$ \\
\hline $\begin{array}{l}\text { Drinking water } \\
\text { containing } \\
\text { boron }\end{array}$ & $\mathrm{S}$ & $\mathrm{Mg} / \mathrm{SS}$ & Batch & 900 & 5 & 20 & 30 & 7 & $\begin{array}{c}\text { B: } 3-7 \\
\text { (optimum } \\
5 \text { ) }\end{array}$ & B: 86 & n.d. & n.d. & n.d. & n.d. & $\begin{array}{c}\text { Vasudevan } \\
\text { et al. 2010 } \\
{[125]}\end{array}$ \\
\hline $\begin{array}{c}\text { Water } \\
\text { containing } \\
\text { cadmium }\end{array}$ & $\mathrm{S}$ & Al-alloy & Batch & $1000^{\mathrm{f}}$ & 5 & $10^{\mathrm{h}} / 20$ & $\begin{array}{c}30 \\
(\mathrm{AC}) \\
45 \\
(\mathrm{DC})\end{array}$ & $\begin{array}{c}6-8 \\
{[7]}\end{array}$ & $\begin{array}{l}\text { Cd: } 10-50 \\
\text { (optimum } \\
20)\end{array}$ & $\begin{array}{c}\text { Cd: } 94^{\mathrm{h}} / 98 \\
\text { (AC) } \\
92^{\mathrm{h}} / 96 \\
\text { (DC) }\end{array}$ & $\begin{array}{c}0.227^{\mathrm{h}} / 0.4 \\
54(\mathrm{AC}) \\
0.881^{\mathrm{h}} / 1.0 \\
02(\mathrm{DC})\end{array}$ & n.d. & n.d. & n.d. & $\begin{array}{c}\text { Vasudevan } \\
\text { et al. 2011 } \\
{[126]}\end{array}$ \\
\hline $\begin{array}{c}\text { Water } \\
\text { containing } \\
\mathrm{Cr}(\mathrm{VI})\end{array}$ & $\mathrm{S}$ & $\begin{array}{c}\mathrm{Fe} / \mathrm{Al}- \\
\mathrm{Al} / \mathrm{Fe} \\
(\mathrm{APC})\end{array}$ & Batch & $700^{f}$ & 15 & $\begin{array}{l}56 / 153 / \\
153 / 222\end{array}$ & $\begin{array}{l}20 / 25 / \\
55 / 110\end{array}$ & $\begin{array}{l}3-5 \\
{\left[5^{c}\right]}\end{array}$ & $\begin{array}{c}\text { Cr(VI): } \\
50 / 100 / \\
500 / 1000\end{array}$ & $\begin{array}{c}\mathrm{Cr}(\mathrm{VI}): \\
98 / 98 / \\
99 / 100\end{array}$ & $\begin{array}{l}4.0 / 16.3 / \\
20.2 / 58.0\end{array}$ & n.d. & n.d. & n.d. & $\begin{array}{c}\text { Keshmirizadeh } \\
\text { et al. } 2011 \\
{[127]}\end{array}$ \\
\hline $\begin{array}{l}\text { Water } \\
\text { containing } \\
\text { copper }\end{array}$ & $\mathrm{S}$ & $\mathrm{Al}$ & Batch & 560 & 15 & $\begin{array}{c}(9.1 / \\
9.0)^{\mathrm{g}} \\
{[\mathrm{V}]}\end{array}$ & $\begin{array}{l}(10.4 / \\
10.2)^{g}\end{array}$ & $6-8$ & $\begin{array}{c}\mathrm{Cu}: \\
2.5-32.5 \\
(\text { optimum } \\
14.2 / 15.0)^{\mathrm{g}}\end{array}$ & $\begin{array}{c}\mathrm{Cu}: \\
(81 / 90)^{\mathrm{g}}\end{array}$ & $\begin{array}{l}(4.07 / \\
6.32)^{\mathrm{e}, \mathrm{g}}\end{array}$ & n.d. & n.d. & n.d. & $\begin{array}{c}\text { Bhatti et al. } \\
2011 \\
{[128]}\end{array}$ \\
\hline $\begin{array}{l}\text { Water } \\
\text { containing } \\
\text { fluoride }\end{array}$ & $\mathrm{S}$ & $\mathrm{Al}$ & Batch & 2000 & 30 & 111 & 25 & 7 & $\begin{array}{l}\text { Fluoride: } \\
25-125 \\
\text { (optimum } \\
25 \text { ) }\end{array}$ & $\begin{array}{l}\text { Fluoride: } \\
\quad 95\end{array}$ & n.d. & n.d. & $\begin{array}{c}0.90- \\
1.05\end{array}$ & n.d. & $\begin{array}{c}\text { Behbahani } \\
\text { et al. 2011 } \\
\text { [129] }\end{array}$ \\
\hline $\begin{array}{l}\text { Aqueous } \\
\text { solution } \\
\text { containing } \\
\text { indium }\end{array}$ & $\mathrm{S}$ & $\mathrm{Fe} / \mathrm{Al}$ & Batch & 500 & 20 & 64 & $\begin{array}{c}50 / 60^{\mathrm{h}} / \\
108^{\mathrm{h}}\end{array}$ & $2.3^{\mathrm{d}}$ & $\begin{array}{c}\text { In: } 20-80 \\
\text { (optimum } \\
20 / 40^{\mathrm{h}} / 80^{\mathrm{h}} \text { ) }\end{array}$ & $\begin{array}{c}\text { In: } \\
90 / 90^{\mathrm{h}} / 90^{\mathrm{h}}\end{array}$ & $\begin{array}{l}\sim 0.002^{\mathrm{e}} / \\
\text { n.d./n.d. }\end{array}$ & $\begin{array}{l}0.085 / \text { n.d. } \\
\text { /n.d. }\end{array}$ & n.d. & n.d. & $\begin{array}{c}\text { Chou \& Huang } \\
2009 \\
{[130]}\end{array}$ \\
\hline $\begin{array}{l}\text { Wastewater } \\
\text { containing } \\
\text { manganese }\end{array}$ & $\mathrm{S}$ & $\mathrm{Al}$ & $\begin{array}{l}\text { Batch + } \\
\text { Aerator }\end{array}$ & 250 & 10 & 62.5 & $\begin{array}{l}(30 / \\
60)^{\mathrm{g}}\end{array}$ & 7 & $\begin{array}{c}\mathrm{Mn}^{2+}: \\
25-400 \\
\text { (optimum } \\
100 \text { ) }\end{array}$ & $\begin{array}{c}\mathrm{Mn}^{2+}: \\
(78 / 94)^{\mathrm{g}}\end{array}$ & n.d. & n.d. & n.d. & n.d. & $\begin{array}{c}\text { Shafaei } \\
\text { et al. 2010 } \\
{[131]}\end{array}$ \\
\hline $\begin{array}{c}\text { Water } \\
\text { containing } \\
\text { phosphate }\end{array}$ & $\mathrm{S}$ & $\begin{array}{c}\mathrm{Al}^{\mathrm{b}} \\
\mathrm{Fe}\end{array}$ & Batch & 5000 & 9 & $\begin{array}{c}(1 / 10 / \\
30 / 50)^{\mathrm{g}}\end{array}$ & $\begin{array}{c}\sim(380 / \\
150 / \\
80 / 25)^{\mathrm{g}}\end{array}$ & n.d. & $\begin{array}{c}\text { Phosphate: } \\
27\end{array}$ & $\begin{array}{l}\text { Phosphate: } \\
(100 / 100 / \\
100 / 100)^{\mathrm{g}}\end{array}$ & $\begin{array}{c}0.06 / \sim 0.3 \\
8^{\mathrm{g} /} \\
\sim 0.58^{\mathrm{g}} / \\
0.73\end{array}$ & n.d. & n.d. & n.d. & $\begin{array}{c}\text { Lacasa } \\
\text { et al. 2011 } \\
{[132]}\end{array}$ \\
\hline $\begin{array}{c}\text { Phosphate- } \\
\text { contaminated } \\
\text { water }\end{array}$ & $\mathrm{S}$ & $\begin{array}{c}\mathrm{Al} / \mathrm{SS} \\
\text { Al-alloy } \\
/ \mathrm{SS}^{\mathrm{b}} \\
\mathrm{Fe} / \mathrm{SS}\end{array}$ & Batch & 900 & 5 & 20 & 30 & $\begin{array}{c}6-9 \\
{[7]}\end{array}$ & $\begin{array}{c}\text { Phosphate: } \\
100\end{array}$ & $\begin{array}{c}\text { Phosphate: } \\
99\end{array}$ & n.d. & n.d. & n.d. & n.d. & $\begin{array}{c}\text { Vasudevan } \\
\text { et al. } 2009 \\
{[133]}\end{array}$ \\
\hline $\begin{array}{c}\text { Water } \\
\text { containing } \\
\text { strontium }\end{array}$ & $\mathrm{S}$ & $\begin{array}{l}\mathrm{Al} \\
\mathrm{SS}^{\mathrm{b}}\end{array}$ & Batch & 200 & 60 & 80 & 50 & $\begin{array}{c}5-7 \\
{[7]}\end{array}$ & $\begin{array}{c}\mathrm{Sr}(\mathrm{II}): \\
10-100 \\
\text { (optimum } \\
10 \text { ) }\end{array}$ & Sr(II): 93 & n.d. & n.d. & $\sim 2^{\mathrm{g}}$ & n.d. & $\begin{array}{c}\text { Murthy \& } \\
\text { Parmar 2011 } \\
{[134]}\end{array}$ \\
\hline $\begin{array}{l}\text { Cyanide-laden } \\
\text { wastewater }\end{array}$ & $\mathrm{S}$ & $\begin{array}{c}\mathrm{Al} \\
\mathrm{Al}-\mathrm{Fe} \\
\mathrm{Fe} \\
\mathrm{Fe}-\mathrm{Al}^{\mathrm{b}}\end{array}$ & $\begin{array}{c}\text { Batch } \\
\text { Continuous }\end{array}$ & $\begin{array}{l}250 \\
250\end{array}$ & $\begin{array}{l}30 \\
30\end{array}$ & 150 & $\begin{array}{c}(20 / 30)^{\mathrm{g}} \\
140^{\mathrm{a}} \\
(0.00671 \\
/ \mathrm{min})\end{array}$ & $9.5^{\mathrm{d}}$ & $\begin{array}{c}\text { Cyanide: } \\
300\end{array}$ & $\begin{array}{c}\text { Cyanide: } \\
(98 / 100)^{\mathrm{g}} \\
100\end{array}$ & n.d. & n.d. & n.d. & n.d. & $\begin{array}{c}\text { Moussavi } \\
\text { et al. 2011 } \\
\text { [135] }\end{array}$ \\
\hline $\begin{array}{l}\text { Contaminated } \\
\text { soil ( } \mathrm{Pb}, \mathrm{Zn} \text {, } \\
\mathrm{Cd}) \text { washing } \\
\text { solution } \\
\text { containing } \\
\text { EDTA }\end{array}$ & $\mathrm{S}$ & $\mathrm{Al} / \mathrm{SS}$ & Batch & 500 & 10 & $160^{\mathrm{g}}$ & $30^{\mathrm{g}}$ & $7.1^{\mathrm{d}}$ & $\begin{array}{c}\text { Pb: } 1220- \\
1620 \\
\text { Zn: } 230- \\
290 \\
\text { Cd: } 8 \text { - } 10 \\
\text { EDTA: } \\
16500- \\
19700\end{array}$ & $\begin{array}{c}\mathrm{Pb}: 95 \\
\mathrm{Zn}: 68 \\
\mathrm{Cd}: 66 \\
\text { EDTA: } \\
\sim 50\end{array}$ & $\sim 8^{\mathrm{e}}$ & n.d. & n.d. & n.d. & $\begin{array}{c}\text { Lestan \& } \\
\text { Pociecha } 2010 \\
{[136]}\end{array}$ \\
\hline
\end{tabular}


Continued

\begin{tabular}{|c|c|c|c|c|c|c|c|c|c|c|c|c|c|c|c|}
\hline $\begin{array}{l}\text { Aqueous } \\
\text { solution } \\
\text { containing } \\
\text { tannic acid } \\
\text { (TA) }\end{array}$ & $\mathrm{S}$ & $\mathrm{Fe}$ & Batch & 200 & 20 & 100 & $75^{\mathrm{e}}$ & $\begin{array}{c}7-9 \\
{[9]}\end{array}$ & TA: 50 & TA: 99 & n.d. & $\begin{array}{c}2.4 \\
\mathrm{kWh} / \mathrm{kg}_{\mathrm{COD}}\end{array}$ & n.d. & n.d. & $\begin{array}{c}\text { Mansouri } \\
\text { et al. 2011 } \\
{[137]}\end{array}$ \\
\hline
\end{tabular}

${ }^{\mathrm{a}}=$ HRT (hydraulic retention time) in EC systems with continuous mode of operation [min]; ${ }^{\mathrm{b}}=$ Observed as the best electrode configuration of those tested; ${ }^{\mathrm{c}}=$ The natural, unmodified $\mathrm{pH}$ value of the water or wastewater (found optimal); ${ }^{\mathrm{d}}=$ The natural, unmodified $\mathrm{pH}$ value of the water or wastewater (the effect of $\mathrm{pH}$ not researched); ${ }^{\mathrm{e}}=$ Approximation calculation based on values given in the paper; ${ }^{\mathrm{f}}=$ Reactor volume (sample volume not mentioned); ${ }^{\mathrm{g}}=$ Optimum value estimated from the data in the article (precise value not given) ${ }^{\mathrm{h}}=$ Additional "optimum value" estimated from the data in the article; n.d. = Not determined.

up to $100 \mathrm{mg} / \mathrm{l}$ were investigated. Even though according to Figure 5 in the article and as mentioned in the text, a neutral initial $\mathrm{pH}$ value was found to be the most efficient, nonetheless $\mathrm{pH} 5$ was chosen as the optimum by the authors. However, the difference between these values was negligible. Raising the temperature above $30^{\circ} \mathrm{C}$ was found to decrease efficiency. Stainless steel was found to be a clearly better electrode material than Al for this application, with optimal removal efficiency of $93 \%$. In this study, removal efficiency was found to greatly improve when the distance between the electrodes was increased [134].

Synthetic wastewater containing $300 \mathrm{mg} / \mathrm{l}$ cyanide was treated by EC operating in both batch and continuous modes. Out of the four electrode combinations tested, $\mathrm{Fe} / \mathrm{Al}$ was found the best-performing, with $\mathrm{Fe} / \mathrm{Fe}$ nearly as effective. When Al was used as the anode material, substantially lower removal efficiencies for cyanide were achieved. Both the batch and continuous EC experiments were conducted using additional aeration in the EC reactor. Aeration was found to improve the efficiency of cyanide removal in the 30 -min batch EC test by approximately 6 percentage points, raising it from $94 \%$ to $100 \%$. Cyanide could be removed completely from the wastewater with EC using both operating modes, although the batch mode was found more efficient (see Table 7). Therefore, EC was concluded to be a promising technique for treating cyanide-laden wastewater [135].

\section{Discussion}

Research on various applications of EC has been conducted extensively around the world recently. A large number of these studies have been conducted in the Middle Eastern countries and India. In these studies EC has been found to be a feasible, economical and ecological alternative in the treatment of various types of water and wastewater with promising results. The interest in EC seems to be on the rise. Apart from a handful of articles, this paper discusses EC literature published in 20082011.

A few of the EC systems studied worked in a hybrid treatment mode (EM, EF, addition of polymer, UV-light, aeration, filtration). RSM has been successfully applied by several authors to optimize the EC process, providing high levels of significance and very low percentages of experimental error (related to theoretical models) in the papers discussed in this study. Therefore, RSM could be applied with EC to find case-specific optimum operating conditions. Duplication or triplication of all test runs was performed in a number of papers. They confirmed that the EC process is repeatable with low (a few percent) experimental error.

Innovations such as collecting the hydrogen gas produced during EC and utilizing it for the EC process's own energy demand (leading to a $13 \%$ decrease in the energy costs of the EC process), solar-powered EC systems, partially recirculating EC sludge supernatant, applying sonar or magnetic field treatment prior to EC (inducing changes in the structure of the studied aqueous solutions, which in turn leads to enhancement of the EC process by a few percentage points), and applying APC have been studied, with promising results.

Most of the authors have conducted their EC studies using small (250 - $2000 \mathrm{ml})$ laboratory-scale reactors with magnetic stirring and virtually all of the EC systems operated in a batch mode. Systems working in a continuous mode and larger scale-up systems have also been investigated, showing promising treatment results and the scalability of the process. Such EC systems should be applied more in future studies.

Slightly over half of the EC studies scrutinized in this paper were carried out using genuine water or wastewater. In a few studies both genuine and synthetic wastewaters modeling a certain similar type of wastewater were used. The wastewater from paper the industry used by the authors was all genuine. Nearly all of the wastewaters from the oil and food industries were also genuine. Synthetic wastewaters have been used much more extensively in the EC studies of tannery, textile, and colored wastewaters, as only a third of such studies discussed here were done using real wastewater. The other types of industrial wastewater studied were mostly genuine.

In nearly all of the studies discussed here, the electrode materials used were made of aluminum, iron, or SS in different combinations, with only a few exceptions. As it can be seen from Tables 1-7, the superiority of different electrode materials seems to vary between different types of aqueous solutions being treated and must therefore always be researched case-specifically. In some of 
the studies, aluminum and iron performed so similarly that a clear choice of the superior material could not be suggested. It must also be taken into consideration that treatment costs and efficiencies are not always the sole factors when choosing between different electrode materials to be used, because other technical aspects (e.g. floc properties, coloration of water by iron, etc.) may also affect the decision-making.

The distance between the electrodes fluctuated between $2-70 \mathrm{~mm}$; however, most setups used by the authors considered here had as electrode gap of $5-20 \mathrm{~mm}$. The effect of this parameter on the feasibility of the EC treatment was rarely studied; e.g. $[10,29,124,134]$. This also applies to the effect of temperature and stirring, although all of these have been shown to have a varied effect on the removal efficiencies of EC $[31,48,115,117$, $120,134,138]$.

Even though the EC process seems to function well over a wide range of $\mathrm{pH}$ values in most studies, generally a relatively narrow $\mathrm{pH}$ range (depending on the electrode materials used) where the process performed optimally could be found. This $\mathrm{pH}$ range was mostly found to be close to neutral $\mathrm{pH}$ values, as observed in Tables 1-7.

The treatment costs and electricity consumption of the EC process in optimal process conditions were not calculated and presented by all the authors, but the aforementioned values were mostly somewhat low when they were presented (typically around $0.1-1.0 € / \mathrm{m}^{3}$ and 0.4 $4.0 \mathrm{kWh} / \mathrm{m}^{3}$, respectively, see Tables 1-7). On the whole, the values for optimal treatment costs and electricity consumption varied greatly between different studies and different types of aqueous solutions, the aforementioned values fluctuating between $0.0047-6.74 € / \mathrm{m}^{3}$ and 0.002 - $58.0 \mathrm{kWh} / \mathrm{m}^{3}$, respectively. However, both values were close to the lower end of the scale presented above.

In most of the papers reviewed in chapter 3.1 the EEC -values were given, most of them being inside or close to a range of $0.1-0.8 \mathrm{kWh} / \mathrm{m}^{3}$. Operating costs were calculated in only two of the papers, however, they were found to be similar in degree: 0.12 and $0.24 € / \mathrm{m}^{3}$, which can be considered very low. Oily wastewaters had economic numbers close to each other. As for OC, $0.2-0.4$ $€ / \mathrm{m}^{3}$ seemed to be an average value, and correspondingly, $2-6 \mathrm{kWh} / \mathrm{m}^{3}$ was the average EEC -value. The results of a very recent investigation of $\mathrm{EC}$ treatment of bio oil-in-water and synthetic oil-in-water emulsions support these findings [139].

Food industry wastewater treated with EC had OC -values in a range of $0.051-4.1 € / \mathrm{m}^{3}$ (given in less than half of the papers). The papers presented in chapter 3.5 had economic numbers presented in about half of the papers and their fluctuation was considerable (between $0.062-6.74 € / \mathrm{m}^{3}$ and $0.14-19.8 \mathrm{kWh} / \mathrm{m}^{3}$ ). This can be considered to be mainly due to the significant variance of water types, compositions, and their pollutant concentrations. Nearly all of the EC treatment results for waters presented in chapter 3.7 had very low OC-values when they were presented; the same is true for EEC-values (see Table 7). This could be mainly due to the fact the waters in this category were synthetic, modeling the removal of only one pollutant at a time and at mostly relatively low concentrations. The publications reviewed in chapters 3.2 and 3.6 had no OC-values given. Paper industry wastewater EEC-values were also absent, whereas in surface water category they fluctuated substantially (between 0.4 $-23.6 \mathrm{kWh} / \mathrm{m}^{3}$ ).

The observed optimal current densities varied greatly, but in most studies they were found to be in the range of $10-150 \mathrm{~A} / \mathrm{m}^{2}$. When the various waters were divided into categories (chapters 3.1 - 3.7), it seems the optimal current density values of oily wastewaters were the highest of all the categories, on average (approx. $160 \mathrm{~A} / \mathrm{m}^{2}$ ). Waters from other industries also had optimal current density values often higher than average. The corresponding value for waters and wastewaters presented in chapters 3.6 and 3.7 were the lowest, on average: approx. $45-50$ and $60-65 \mathrm{~A} / \mathrm{m}^{2}$, respectively. Both water categories had most of their optimal current values inside the range of $5-60 \mathrm{~A} / \mathrm{m}^{2}$. For wastewaters presented in chapter 3.5, optimal current density values were largely in the range of $100-150 \mathrm{~A} / \mathrm{m}^{2}$. These observations could be related to the high levels of pollutants in oily and other industrial wastewaters and, on the contrary, to surface waters and modeled waters and wastewaters being only mildly polluted in comparison, with relatively low concentrations of pollutants.

One of the advantages of the EC process is its fast treatment capability, and in a vast majority of the studies discussed in this paper, optimal treatment times were found to be in the range of $5-60 \mathrm{~min}$ (these figures do not take required sedimentation times into account, which are generally rather short). More than half of the authors found an optimum treatment time of $30 \mathrm{~min}$ or less. In some cases a two-to three-hour EC treatment time was needed, however some wastewater could be purified rapidly in a few minutes. As with other functional parameters, treatment duration seems to be strongly dependent on the type of water being purified and its concentration. The applied current density also has a significant impact on treatment duration.

\section{Conclusions}

The range of feasible EC applications is expanding. In a vast majority of the studies discussed in this paper, optimal treatment times were found to be in the range of 5 $60 \mathrm{~min}$ (not taking into account required sedimentation times). More than half of the authors found an optimum treatment time of $30 \mathrm{~min}$ or less. Observed optimal cur- 
rent densities varied greatly, but in most studies they were found to be in the range of $10-150 \mathrm{~A} / \mathrm{m}^{2}$. Even though the EC process seems to function well over a wide range of $\mathrm{pH}$ values in most studies, generally a relatively narrow $\mathrm{pH}$ range could be found where the process performed optimally. This $\mathrm{pH}$ range was mostly found to be close to the neutral $\mathrm{pH}$ value.

The superiority of different electrode materials seems to vary between different types of aqueous solutions being treated, and must therefore always be studied casespecifically. Both $\mathrm{OC}$ and EEC-values were found to fluctuate greatly between different water types being treated, between $0.0047-6.74 € / \mathrm{m}^{3}$ and $0.002-58.0$ $\mathrm{kWh} / \mathrm{m}^{3}$, but they were generally rather low (typically around $0.1-1.0 € / \mathrm{m}^{3}$ and $0.4-4.0 \mathrm{kWh} / \mathrm{m}^{3}$, respectively). To conclude, EC has great potential in purification of various types of water and wastewater and seems to be a feasible and economical alternative in this field, although more research is needed, especially using larger-scale and/or continuous systems and focusing on the fundamentals of the EC process.

\section{Acknowledgements}

This study was supported by Maa-ja vesitekniikan tuki ry. and Academy of Finland (AquAlSi-project). Expression of gratitude is presented to Authorized Translator Keith Kosola for revising the language.

\section{REFERENCES}

[1] P. K. Holt, G. W. Barton and C. A. Mitchell, "The Future for Electrocoagulation as a Localised Water Treatment Technology," Chemosphere, Vol. 59, No. 3, 2005, pp. 355-367. doi:10.1016/j.chemosphere.2004.10.023

[2] G. Chen, "Electrochemical Technologies in Wastewater Treatment," Separation and Purification Technology, Vol. 38 , No. 1, 2004, pp. 11-41. doi:10.1016/j.seppur.2003.10.006

[3] M. M. Emamjomeh and M. Sivakumar, "Review of Pollutants Removed by Electrocoagulation and Electrocoagulation/Flotation Processes," Journal of Environmental Management, Vol. 90, No. 5, 2009, pp. 1663-1679. doi:10.1016/j.jenvman.2008.12.011

[4] E. Butler, Y.-T. Hung, R. Y.-L. Yeh and M. S. Al Ahmad, "Electrocoagulation in Wastewater Treatment," Water, Vol. 3, No. 2, 2011, pp. 495-525. doi:10.3390/w3020495

[5] M. Y. A. Mollah, R. Schennach, J. R. Parga and D. L. Cocke, "Electrocoagulation (EC) - Science and Applications," Journal of Hazardous Materials, Vol. 84, No. 1, 2001, pp. 29-41. doi:10.1016/S0304-3894(01)00176-5

[6] P. R. Kumar, S. Chaudhari, K. C. Khilar and S. P. Mahajan, "Removal of Arsenic from Water by Electrocoa- gulation," Chemosphere, Vol. 55, No. 9, 2004, pp. 12451252. doi:10.1016/j.chemosphere.2003.12.025

[7] X. Chen, G. Chen and P. L. Yue, "Separation of Pollutants from Restaurant Wastewater by Electrocoagu- la- tion," Separation and Purification Technology, Vol. 19, No. 1-2, 2000, pp. 65-76. doi:10.1016/S1383-5866(99)00072-6

[8] S. Zodi, O. Potier, F. Lapicque and J. Leclerc, "Treatment of the Textile Wastewaters by Electrocoagulation: Effect of Operating Parameters on the Sludge Settling Characteristics," Separation and Purification Technology, Vol. 69, No. 1, 2009, pp. 29-36.

doi:10.1016/j.seppur.2009.06.028

[9] S. Gao, M. Du, J. Tian, J. Yang, J. Yang, F. Ma and J. Nan, "Effects of Chloride Ions on Electro-CoagulationFlotation Process with Aluminum Electrodes for Algae Removal," Journal of Hazardous Materials, Vol. 182, No. 1-3, 2010, pp. 827-834. doi:10.1016/j.jhazmat.2010.06.114

[10] E. Terrazas, A. Vázquez, R. Briones, I. Lázaro and I. Rodríguez, "EC Treatment for Reuse of Tissue Paper Wastewater: Aspects That Affect Energy Consumption," Journal of Hazardous Materials, Vol. 181, No. 1-3, 2010, pp. 809-816. doi:10.1016/j.jhazmat.2010.05.086

[11] S. Kongjao, S. Damronglerd and M. Hunsom, "Simultaneous Removal of Organic and Inorganic Pollutants in Tannery Wastewater Using Electrocoagulation Technique," Korean Journal of Chemical Engineering, Vol. 25, No. 4, 2008, pp. 703-709.

doi:10.1007/s11814-008-0115-1

[12] İ. A. Şengil and M. Özacar, "The Decolorization of C.I. Reactive Black 5 in Aqueous Solution by Electrocoa- gulation Using Sacrificial Iron Electrodes," Journal of Hazardous Materials, Vol. 161, No. 2-3, 2009, pp. 13691376. doi:10.1016/j.jhazmat.2008.04.100

[13] M. Kobya, F. Ulu, U. Gebologlu, E. Demirbas and M. S. Oncel, "Treatment of Potable Water Containing Low Concentration of Arsenic with Electrocoagulation: Different Connection Modes and Fe-Al Electrodes," Separation and Purification Technology, Vol. 77, No. 3, 2011, pp. 283-293. doi:10.1016/j.seppur.2010.12.018

[14] G. Mouedhen, M. Feki, M. D. P. Wery and H. F. Ayedi, "Behavior of Aluminum Electrodes in Electrocoagulation Process," Journal of Hazardous Materials, Vol. 150, No. 1, 2008, pp. 124-135. doi:10.1016/j.jhazmat.2007.04.090

[15] K. Yetilmezsoy, F. Ilhan, Z. Sapci-Zengin, S. Sakar and M. T. Gonullu, "Decolorization and COD Reduction of UASB Pretreated Poultry Manure Wastewater by Electrocoagulation Process: A Post-Treatment Study," Journal of Hazardous Materials, Vol. 162, No. 1, 2009, pp. 120-132. doi:10.1016/j.jhazmat.2008.05.015

[16] M. Rebhun and M. Lurie, "Control of Organic Matter by Coagulation and Floc Separation," Water Science and Technology, Vol. 27, No. 11, 1993, pp. 1-20.

[17] M. Kobya, O. T. Can and M. Bayramoglu, "Treatment of Textile Wastewaters by Electrocoagulation Using Iron and Aluminum Electrodes," Journal of Hazardous Materials, Vol. 100, No. 1-3, 2003, pp. 163-178. doi:10.1016/S0304-3894(03)00102-X

[18] L. D. Benefield, J. F. Judkins and B. L. Weand, "Process Chemistry for Water and Wastewater Treatment," Prentice-Hall, Englewood Cliffs, 1982.

[19] A. J. Rubin, “Aqueous-Environmental Chemistry of Me- 
tals," Ann Arbor Science Publishers, Ann Arbor, 1974.

[20] F. Akbal and S. Camc1, "Comparison of Electrocoagulation and Chemical Coagulation for Heavy Metal Removal," Chemical Engineering \& Technology, Vol. 33, No. 10, 2010, pp. 1655-1664. doi:10.1002/ceat.201000091

[21] J. Duan and J. Gregory, "Coagulation by Hydrolysing Metal Salts," Advances in Colloid and Interface Science, Vol. 100-102, 2003, pp. 475-502. doi:10.1016/S0001-8686(02)00067-2

[22] A. Kumar, "Tannery Effluent," In: M. Doble and A. Kumar, Eds., Biotreatment of Industrial Effluents, Butterworth-Heinemann, Burlington, 2005, pp. 133-143.

[23] R. M. Makdisi, "Tannery Wastes Definition, Risk Assessment and Cleanup Options, Berkeley, California," Journal of Hazardous Materials, Vol. 29, No. 1, 1991, pp. 7996. doi:10.1016/0304-3894(91)87075-D

[24] N. M. Mahmoodi, M. Arami, N. Y. Limaee and N. S. Tabrizi, "Decolorization and Aromatic Ring Degradation Kinetics of Direct Red 80 by UV Oxidation in the Presence of Hydrogen Peroxide Utilizing $\mathrm{TiO}_{2}$ as a Photocatalyst," Chemical Engineering Journal, Vol. 112, No. 1-3, 2005, pp. 191-196. doi:10.1016/j.cej.2005.07.008

[25] Y. Yalçın Şevki, "Optimization of Bomaplex Red CR-L Dye Removal from Aqueous Solution by Electrocoagulation Using Aluminum Electrodes," Journal of Hazardous Materials, Vol. 153, No. 1-2, 2008, pp. 194-200. doi:10.1016/i.jhazmat.2007.08.034

[26] O. Apaydin, U. Kurt and M. T. Gönüllü, “An Investigation on the Treatment of Tannery Wastewater by Electrocoagulation," Global Nest Journal, Vol. 11, No. 4, 2009, pp. 546-555.

[27] L. Szpyrkowicz, S. N. Kaul and R. N. Neti, "Tannery Wastewater Treatment by Electro-Oxidation Coupled with a Biological Process," Journal of Applied Electrochemistry, Vol. 35, No. 4, 2005, pp. 381-390. doi:10.1007/s10800-005-0796-7

[28] S. Zodi, O. Potier, F. Lapicque and J. Leclerc, “Treatment of the Industrial Wastewaters by Electrocoagulation: Optimization of Coupled Electrochemical and Sedimen- tation Processes," Desalination, Vol. 261, No. 1-2, 2010 , pp. 186-190. doi:10.1016/j.desal.2010.04.024

[29] S. Aoudj, A. Khelifa, N. Drouiche, M. Hecini and H. Hamitouche, "Electrocoagulation Process Applied to Wastewater Containing Dyes from Textile Industry," Chemical Engineering and Processing: Process Intensification, Vol. 49, No. 11, 2010, pp. 1176-1182. doi:10.1016/j.cep.2010.08.019

[30] C. Phalakornkule, P. Sukkasem and C. Mutchimsattha, "Hydrogen Recovery from the Electrocoagulation Treatment of Dye-Containing Wastewater," International Journal of Hydrogen Energy, Vol. 35, No. 20, 2010, pp. 10934-10943. doi:10.1016/j.ijhydene.2010.06.100

[31] C. Phalakornkule, S. Polgumhang, W. Tongdaung, B. Karakat and T. Nuyut, "Electrocoagulation of Blue Reactive, Red Disperse and Mixed Dyes, and Application in Treating Textile Effluent," Journal of Environmental Management, Vol. 91, No. 4, 2010, pp. 918-926. doi:10.1016/j.jenvman.2009.11.008
[32] P. Durango-Usuga, F. Guzmán-Duque, R. Mosteo, M. V. Vazquez, G. Peñuela and R. A. Torres-Palma, "Experimental Design Approach Applied to the Elimination of Crystal Violet in Water by Electrocoagulation with $\mathrm{Fe}$ or Al Electrodes," Journal of Hazardous Materials, Vol. 179, No. 1-3, 2010, pp. 120-126. doi:10.1016/j.jhazmat.2010.02.067

[33] E. Z. El-Ashtoukhy and N. K. Amin, "Removal of Acid Green Dye 50 from Wastewater by Anodic Oxidation and Electrocoagulation-A Comparative Study," Journal of Hazardous Materials, Vol. 179, No. 1-3, 2010, pp. 113119. doi:10.1016/j.jhazmat.2010.02.066

[34] J. B. Parsa, H. R. Vahidian, A. R. Soleymani and M. Abbasi, "Removal of Acid Brown 14 in Aqueous Media by Electrocoagulation: Optimization Parameters and Minimizing of Energy Consumption," Desalination, Vol. 278, No. 1-3, 2011, pp. 295-302. doi:10.1016/j.desal.2011.05.040

[35] A. Aleboyeh, N. Daneshvar and M. B. Kasiri, "Optimization of C.I. Acid Red 14 Azo Dye Removal by Electrocoagulation Batch Process with Response Surface Methodology," Chemical Engineering and Processing: Process Intensification, Vol. 47, No. 5, 2008, pp. 827-832. doi:10.1016/j.cep.2007.01.033

[36] M. Y. A. Mollah, J. A. G. Gomes, K. K. Das and D. L. Cocke, "Electrochemical Treatment of Orange II Dye Solution-Use of Aluminum Sacrificial Electrodes and Floc Characterization," Journal of Hazardous Materials, Vol. 174, No. 1-3, 2010, pp. 851-858.

doi:10.1016/j.jhazmat.2009.09.131

[37] M. S. Secula, I. Creţescu and S. Petrescu, "An Experimental Study of Indigo Carmine Removal from Aqueous Solution by Electrocoagulation," Desalination, Vol. 277, No. 1-3, 2011, pp. 227-235. doi:10.1016/j.desal.2011.04.031

[38] B. Merzouk, B. Gourich, A. Sekki, K. Madani, C. Vial and M. Barkaoui, "Studies on the Decolorization of Textile Dye Wastewater by Continuous Electrocoagulation Process," Chemical Engineering Journal, Vol. 149, No. 1-3, 2009, pp. 207-214. doi:10.1016/j.cej.2008.10.018

[39] F. Zidane, P. Drogui, B. Lekhlif, J. Bensaid, J. F. Blais, S. Belcadi and K. El Kacemi, "Decolourization of DyeContaining Effluent Using Mineral Coagulants Produced by Electrocoagulation," Journal of Hazardous Materials, Vol. 155, No. 1-2, 2008, pp. 153-163. doi:10.1016/j.jhazmat.2007.11.041

[40] A. R. Khataee, V. Vatanpour and A. R. Amani Ghadim, "Decolorization of C.I. Acid Blue 9 Solution by UV/ Nano-TiO 2 , Fenton, Fenton-Like, Electro-Fenton and Electrocoagulation Processes: A Comparative Study," Journal of Hazardous Materials, Vol. 161, No. 2-3, 2009, pp. 1225-1233. doi:10.1016/j.jhazmat.2008.04.075

[41] A. H. Essadki, M. Bennajah, B. Gourich, C. Vial, M. Azzi and H. Delmas, "Electrocoagulation/Electroflotation in an External-Loop Airlift Reactor-Application to the Decolorization of Textile Dye Wastewater: A Case Study," Chemical Engineering and Processing: Process Intensification, Vol. 47, No. 8, 2008, pp. 1211-1223. doi:10.1016/j.cep.2007.03.013

[42] B. Merzouk, M. Yakoubi, I. Zongo, J.-P. Leclerc, G. Pa- 
ternotte, S. Pontvianne and F. Lapicque, "Effect of Modification of Textile Wastewater Composition on Electrocoagulation Efficiency," Desalination, Vol. 275, No. 1-3, 2011, pp. 181-186. doi:10.1016/j.desal.2011.02.055

[43] A. Benhadji, M. Taleb Ahmed and R. Maachi, "Electrocoagulation and Effect of Cathode Materials on the Removal of Pollutants from Tannery Wastewater of Rouïba," Desalination, Vol. 277, No. 1-3, 2011, pp. 128-134. doi:10.1016/j.desal.2011.04.014

[44] K. S. P. Kalyani, N. Balasubramanian and C. Srinivasakannan, "Decolorization and COD Reduction of Paper Industrial Effluent Using Electro-Coagulation," Chemical Engineering Journal, Vol. 151, No. 1-3, 2009, pp. 97-104. doi:10.1016/j.cej.2009.01.050

[45] M. Zaied and N. Bellakhal, "Electrocoagulation Treatment of Black Liquor from Paper Industry," Journal of Hazardous Materials, Vol. 163, No. 2-3, 2009, pp. 9951000. doi:10.1016/j.jhazmat.2008.07.115

[46] M. Uğurlu, A. Gürses, Ç. Doğar and M. Yalçın, "The Removal of Lignin and Phenol from Paper Mill Effluents by Electrocoagulation," Journal of Hazardous Materials, Vol. 87, No. 3, 2008, pp. 420-428. doi:10.1016/j.jenvman.2007.01.007

[47] S. Zodi, J. Louvet, C. Michon, O. Potier, M. Pons, F. Lapicque and J. Leclerc, "Electrocoagulation as a Tertiary Treatment for Paper Mill Wastewater: Removal of NonBiodegradable Organic Pollution and Arsenic," Sepa- ration and Purification Technology, Vol. 81 , No. 1, 2011, pp. 62-68. doi:10.1016/j.seppur.2011.07.002

[48] R. Katal and H. Pahlavanzadeh, "Influence of Different Combinations of Aluminum and Iron Electrode on Electrocoagulation Efficiency: Application to the Treatment of Paper Mill Wastewater," Desalination, Vol. 265, No. 1-3, 2011, pp. 199-205. doi:10.1016/j.desal.2010.07.052

[49] M. Vepsäläinen, H. Kivisaari, M. Pulliainen, A. Oikari and M. Sillanpää, "Removal of Toxic Pollutants from Pulp Mill Effluents by Electrocoagulation," Separation and Purification Technology, Vol. 81, No. 2, 2011, pp. 141-150. doi:10.1016/j.seppur.2011.07.017

[50] S. Bellebia, S. Kacha, A. Z. Bouyakoub and Z. Derriche, "Experimental Investigation of Chemical Oxygen Demand and Turbidity Removal from Cardboard Paper Mill Effluents Using Combined Electrocoagulation and Adsorption Processes," Environmental Progress \& Sustainable Energy, Vol. 31, No. 3, 2011, pp. 361-370. doi:10.1002/ep.10556

[51] M. Hanafy and H. I. Nabih, "Treatment of Oily Wastewater Using Dissolved Air Flotation Technique," Energy Sources, Part A: Recovery, Utilization and Environmental Effects, Vol. 29, No. 2, 2007, pp. 143-159. doi:10.1080/009083190948711

[52] E. GilPavas, K. Molina-Tirado and M. Á. Gómez-García, "Treatment of Automotive Industry Oily Wastewater by Electrocoagulation: Statistical Optimization of the Operational Parameters," Water Science and Technology, Vol. 60 , No. 10, 2009, pp. 2581-2588. doi:10.2166/wst.2009.519

[53] M. Saeedi and A. Khalvati-Fahlyani, "Treatment of Oily Wastewater of a Gas Refinery by Electrocoagulation Us- ing Aluminum Electrodes," Water Environment Research, Vol. 83, No. 3, 2011, pp. 256-264. doi:10.2175/106143010X12780288628499

[54] P. Drogui, M. Asselin, S. K. Brar, H. Benmoussa and J.-F. Blais, "Electrochemical Removal of Organics and Oil from Sawmill and Ship Effluents," Canadian Journal of Civil Engineering, Vol. 36, No.3, 2009, pp. 529-539. doi:10.1139/L09-003

[55] P. Cañizares, F. Martínez, C. Jiménez, C. Sáez and M. A. Rodrigo, "Coagulation and Electrocoagulation of Oil-inWater Emulsions," Journal of Hazardous Materials, Vol. 151, No. 1, 2008, pp. 44-51. doi:10.1016/j.jhazmat.2007.05.043

[56] P. Cañizares, C. Jiménez, F. Martínez, M. A. Rodrigo and C. Sáez, "The pH as a Key Parameter in the Choice between Coagulation and Electrocoagulation for the Treatment of Wastewaters," Journal of Hazardous Materials, Vol. 163, No. 1, 2009, pp. 158-164. doi:10.1016/j.jhazmat.2008.06.073

[57] C. J. Izquierdo, P. Cañizares, M. A. Rodrigo, J. P. Leclerc, G. Valentin and F. Lapicque, "Effect of the Nature of the Supporting Electrolyte on the Treatment of Soluble Oils by Electrocoagulation," Desalination, Vol. 255, No. 1-3, 2010, pp. 15-20. doi:10.1016/j.desal.2010.01.022

[58] K. Bensadok, S. Benammar, F. Lapicque and G. Nezzal, "Electrocoagulation of Cutting Oil Emulsions Using Aluminium Plate Electrodes," Journal of Hazardous Materials, Vol. 152, No. 1, 2008, pp. 423-430. doi:10.1016/j.jhazmat.2007.06.121

[59] M. H. El-Naas, S. Al-Zuhair, A. Al-Lobaney and S. Makhlouf, "Assessment of Electrocoagulation for the Treatment of Petroleum Refinery Wastewater," Journal of Hazardous Materials, Vol. 91, No. 1, 2009, pp. 180-185. doi:10.1016/i.jenvman.2009.08.003

[60] M. B. Agustin, W. P. Sengpracha and W. Phutdhawong, "Electrocoagulation of Palm Oil Mill Effluent," International Journal of Environmental Research and Public Health, Vol. 5 , No. 3, 2008, pp. 177-180. doi:10.3390/ijerph5030177

[61] T. J. Ahmad and D. Zawawi, "Palm Oil Mill Effluent (POME) Treatment by Using an Electrocoagulation Method," Research Journal of Chemistry and Environment, Vol. 15, No. 2, 2011, pp. 606-609.

[62] M. Tir and N. Moulai-Mostefa, "Optimization of Oil Removal from Oily Wastewater by Electrocoagulation Using Response Surface Method," Journal of Hazardous Materials, Vol. 158, No. 1, 2008, pp. 107-115. doi:10.1016/j.jhazmat.2008.01.051

[63] M. Asselin, P. Drogui, S. K. Brar, H. Benmoussa and J. Blais, "Organics Removal in Oily Bilgewater by Electrocoagulation Process," Journal of Hazardous Materials, Vol. 151, No. 2-3, 2008, pp. 446-455. doi:10.1016/j.jhazmat.2007.06.008

[64] U. Tezcan Un, A. S. Koparal and U. Bakir Ogutveren, "Electrocoagulation of Vegetable Oil Refinery Wastewater Using Aluminum Electrodes," Journal of Environmental Management, Vol. 90 , No. 1, 2009, pp. 428-433. doi:10.1016/i.jenvman.2007.11.007

[65] Y. Meas, J. A. Ramirez, M. A. Villalon and T. W. Chap- 
man, "Industrial Wastewaters Treated by Electrocoagulation," Electrochimica Acta, Vol. 55, No. 27, 2010, pp. 8165-8171. doi:10.1016/j.electacta.2010.05.018

[66] F. Hanafi, O. Assobhei and M. Mountadar, "Detoxification and Discoloration of Moroccan Olive Mill Wastewater by Electrocoagulation," Journal of Hazardous Materials, Vol. 174, No. 1-3, 2010, pp. 807-812. doi:10.1016/j.jhazmat.2009.09.124

[67] M. Kobya, C. Ciftci, M. Bayramoglu and M. T. Sensoy, "Study on the Treatment of Waste Metal Cutting Fluids Using Electrocoagulation," Separation and Purification Technology, Vol. 60, No. 3, 2008, pp. 285-291. doi:10.1016/j.seppur.2007.09.003

[68] G. Moussavi, R. Khosravi and M. Farzadkia, "Removal of Petroleum Hydrocarbons from Contaminated Groundwater Using an Electrocoagulation Process: Batch and Continuous Experiments," Desalination, Vol. 278, No. 1-3, 2011, pp. 288-294. doi:10.1016/j.desal.2011.05.039

[69] K. Suehara, Y. Kawamoto, E. Fujii, J. Kohda, Y. Nakano and T. Yano, "Biological Treatment of Wastewater Discharged from Biodiesel Fuel Production Plant with Alkali-Catalyzed Transesterification," Journal of Bioscience and Bioengineering, Vol. 100, No. 4, 2005, pp. 437442. doi: $10.1263 / \mathrm{jbb} .100 .437$

[70] O. Chavalparit and M. Ongwandee, "Optimizing Electrocoagulation Process for the Treatment of Biodiesel Wastewater Using Response Surface Methodology," Journal of Environmental Sciences, Vol. 21, No. 11, 2009, pp. 14911496. doi:10.1016/S1001-0742(08)62445-6

[71] Y. Avsar, U. Kurt and T. Gonullu, "Comparison of Classical Chemical and Electrochemical Processes for Treating Rose Processing Wastewater," Journal of Hazardous Materials, Vol. 148, No. 1-2, 2007, pp. 340-345. doi:10.1016/j.jhazmat.2007.02.048

[72] B. Demirel, O. Yenigun and T. T. Onay, "Anaerobic Treatment of Dairy Wastewaters: A Review," Process Biochemistry, Vol. 40, No. 8, 2005, pp. 2583-2595. doi:10.1016/j.procbio.2004.12.015

[73] İ. A. Şengil and M. Özacar, "Treatment of Dairy Wastewaters by Electrocoagulation Using Mild Steel Electrodes," Journal of Hazardous Materials, Vol. 137, No. 2, 2006, pp. 1197-1205. doi:10.1016/j.jhazmat.2006.04.009

[74] B. Balannec, M. Vourch, M. Rabiller-Baudry and B. Chaufer, "Comparative Study of Different Nanofiltration and Reverse Osmosis Membranes for Dairy Effluent Treatment by Dead-End Filtration," Separation and Purification Technology, Vol. 42, No. 2, 2005, pp. 195-200. doi:10.1016/j.seppur.2004.07.013

[75] K. Bensadok, N. El Hanafi and F. Lapicque, "Electrochemical Treatment of Dairy Effluent Using Combined $\mathrm{Al}$ and Ti/Pt Electrodes System," Desalination, Vol. 280, No. 1-3, 2011, pp. 244-251. doi:10.1016/j.desal.2011.07.006

[76] S. Tchamango, C. P. Nanseu-Njiki, E. Ngameni, D. Hadjiev and A. Darchen, "Treatment of Dairy Effluents by Electrocoagulation Using Aluminium Electrodes," Science of the Total Environment, Vol. 408, No. 8, 2010, pp. 947-952. doi:10.1016/j.scitotenv.2009.10.026

[77] J. P. Kushwaha, V. C. Srivastava and I. D. Mall, "Orga- nics Removal from Dairy Wastewater by Electrochemical Treatment and Residue Disposal," Separation and Purification Technology, Vol. 76, No. 2, 2010, pp. 198-205. doi:10.1016/j.seppur.2010.10.008

[78] M. Kobya, H. Hiz, E. Senturk, C. Aydiner and E. Demirbas, "Treatment of Potato Chips Manufacturing Wastewater by Electrocoagulation," Desalination, Vol. 190, No. 1-3, 2006, pp. 201-211. doi:10.1016/j.desal.2005.10.006

[79] D. Valero, J. M. Ortiz, V. García, E. Expósito, V. Montiel and A. Aldaz, "Electrocoagulation of Wastewater from Almond Industry," Chemosphere, Vol. 84, No. 9, 2011, pp. 1290-1295. doi:10.1016/j.chemosphere.2011.05.032

[80] G. Roa-Morales, E. Campos-Medina, J. Aguilera-Cotero, B. Bilyeu and C. Barrera-Díaz, "Aluminum Electrocoagulation with Peroxide Applied to Wastewater from Pasta and Cookie Processing," Separation and Purification Technology, Vol. 54, No. 1, 2007, pp. 124-129. doi:10.1016/j.seppur.2006.08.025

[81] M. Asselin, P. Drogui, H. Benmoussa and J. Blais, "Effectiveness of Electrocoagulation Process in Removing Organic Compounds from Slaughterhouse Wastewater Using Monopolar and Bipolar Electrolytic Cells," Chemosphere, Vol. 72, No. 11, 2008, pp. 1727-1733. doi:10.1016/j.chemosphere.2008.04.067

[82] L. J. Xu, B. W. Sheldon, D. K. Larick and R. E. Carawan, "Recovery and Utilization of Useful By-Products from Egg Processing Wastewater by Electrocoagulation," Poultry Science, Vol. 81, No. 6, 2002, pp. 785-792.

[83] M. Kobya and S. Delipinar, "Treatment of the Baker's Yeast Wastewater by Electrocoagulation," Journal of Hazardous Materials, Vol. 154, No. 1-3, 2008, pp. 11331140. doi:10.1016/j.jhazmat.2007.11.019

[84] J. K. Maghanga, F. K. Segor, L. Etiégni and J. Lusweti, "Electrocoagulation Method for Colour Removal in Tea Effluent: A Case Study of Chemomi Tea Factory in Rift Valley, Kenya," Bulletin of the Chemical Society of Ethiopia, Vol. 23, No. 3, 2009, pp. 371-381. doi:10.4314/bcse.v23i3.47661

[85] I. Linares-Hernández, C. Barrera-Díaz, G. Roa-Morales, B. Bilyeu and F. Ureña-Núñez, "Influence of the Anodic Material on Electrocoagulation Performance," Chemical Engineering Journal, Vol. 148, No. 1, 2009, pp. 97-105. doi:10.1016/j.cej.2008.08.007

[86] M. R. V. Lanza and R. Bertazzoli, "Cyanide Oxidation from Wastewater in a Flow Electrochemical Reactor," Industrial and Engineering Chemistry Research, Vol. 41, No. 1, 2002, pp. 22-26.

[87] M. Kobya, E. Demirbas, N. U. Parlak and S. Yigit, "Treatment of Cadmium and Nickel Electroplating Rinse Water by Electrocoagulation," Environmental Technology, Vol. 31, No. 13, 2010, pp. 1471-1481. doi:10.1080/09593331003713693

[88] I. Heidmann and W. Calmano, "Removal of $\mathrm{Ni}, \mathrm{Cu}$ and $\mathrm{Cr}$ from a Galvanic Wastewater in an Electrocoagulation System with Fe- and Al-Electrodes," Separation and $\mathrm{Pu}$ rification Technology, Vol. 71, No. 3, 2010, pp. 308- 314. doi:10.1016/j.seppur.2009.12.016

[89] F. Akbal and S. Camc1, "Copper, Chromium and Nickel Removal from Metal Plating Wastewater by Electrocoa- 
gulation," Desalination, Vol. 269, No. 1-3, 2011, pp. 214222. doi:10.1016/j.desal.2010.11.001

[90] I. Kabdaşl1, T. Arslan, T. Ölmez-Hanc1, I. Arslan-Alaton and O. Tünay, "Complexing Agent and Heavy Metal Removals from Metal Plating Effluent by Electrocoa- gulation with Stainless Steel Electrodes," Journal of Hazardous Materials, Vol. 165, No. 1-3, 2009, pp. 838-845. doi:10.1016/i.jhazmat.2008.10.065

[91] M. Kobya, E. Demirbas, A. Dedeli and M. T. Sensoy, "Treatment of Rinse Water from Zinc Phosphate Coating by Batch and Continuous Electrocoagulation Processes," Journal of Hazardous Materials, Vol. 173, No. 1-3, 2010, pp. 326-334. doi:10.1016/j.jhazmat.2009.08.092

[92] C. Wang, W. Chou, L. Chen and S. Chang, "Silica Particles Settling Characteristics and Removal Performances of Oxide Chemical Mechanical Polishing Wastewater Treated by Electrocoagulation Technology," Journal of Hazardous Materials, Vol. 161, No. 1, 2009, pp. 344-350. doi:10.1016/j.jhazmat.2008.03.099

[93] C.-T. Wang and W.-L. Chou, "Performance of COD Removal from Oxide Chemical Mechanical Polishing Wastewater Using Iron Electrocoagulation," Journal of Environmental Science and Health-Part A Toxic/Hazardous Substances and Environmental Engineering, Vol. 44, No. 12, 2009, pp. 1289-1297. doi:10.1080/10934520903140090

[94] M. Panizza and G. Cerisola, "Applicability of Electrochemical Methods to Carwash Wastewaters for Reuse. Part 2: Electrocoagulation and Anodic Oxidation Integrated Process," Journal of Electroanalytical Chemistry, Vol. 638, No. 2, 2010, pp. 236-240. doi:10.1016/i.jelechem.2009.11.003

[95] M. Kumar, F. I. A. Ponselvan, J. R. Malviya, V. C. Srivastava and I. D. Mall, "Treatment of Bio-Digester Effluent by Electrocoagulation Using Iron Electrodes," Journal of Hazardous Materials, Vol. 165, No. 1-3, 2009, pp. 345-352. doi:10.1016/i.jhazmat.2008.10.041

[96] D. Ryan, A. Gadd, J. Kavanagh, M. Zhou and G. Barton, "A Comparison of Coagulant Dosing Options for the Remediation of Molasses Process Water," Separation and Purification Technology, Vol. 58, No. 3, 2008, pp. 347352. doi:10.1016/j.seppur.2007.05.010

[97] L. Zhang, G. Xue, N. Zhang, S. Liu, A. Duan and L. Wang, "Decolorization Study of Coking Wastewater by Continuous Electrocoagulation Process," ICMREE2011-Proedings 2011 International Conference on Materials for Renewable Energy and Environment, Shanghai, May 2011, pp. 860-863.

[98] J. Zhu, F. Wu, X. Pan, J. Guo and D. Wen, "Removal of Antimony from Antimony Mine Flotation Wastewater by Electrocoagulation with Aluminum Electrodes," Journal of Environmental Sciences, Vol. 23, No. 7, 2011, pp. 1066-1071. doi:10.1016/S1001-0742(10)60550-5

[99] F. Janpoor, A. Torabian and V. Khatibikamal, "Treatment of Laundry Waste-Water by Electrocoagulation," Journal of Chemical Technology and Biotechnology, Vol. 86, No. 8, 2011, pp. 1113-1120. doi:10.1002/jctb.2625

[100] C. Wang, W. Chou and Y. Kuo, "Removal of COD from Laundry Wastewater by Electrocoagulation/Electroflota- tion," Journal of Hazardous Materials, Vol. 164, No. 1, 2009, pp. 81-86. doi:10.1016/j.jhazmat.2008.07.122

[101] A. Akyol, "Treatment of Paint Manufacturing Wastewater by Electrocoagulation," Desalination, Vol. 285, 2012, pp. 91-99. doi:10.1016/j.desal.2011.09.039

[102] M. Solak, M. Kılıç, Y. Hüseyin and A. Şencan, "Removal of Suspended Solids and Turbidity from Marble Pro- cessing Wastewaters by Electrocoagulation: Comparison of Electrode Materials and Electrode Connection Systems," Journal of Hazardous Materials, Vol. 172, No. 1, 2009, pp. 345-352. doi:10.1016/j.jhazmat.2009.07.018

[103] W. Chou, C. Wang and K. Huang, "Investigation of Process Parameters for the Removal of Polyvinyl Alcohol from Aqueous Solution by Iron Electrocoagulation," Desalination, Vol. 251, No. 1-3, 2010, pp. 12-19. doi:10.1016/j.desal.2009.10.008

[104] W. Chou, C. Wang, K. Huang and T. Liu, "Electrochemical Removal of Salicylic Acid from Aqueous Solutions Using Aluminum Electrodes," Desalination, Vol. 271, No. 1-3, 2011, pp. 55-61. doi:10.1016/j.desal.2010.12.013

[105] M. Malakootian, H. J. Mansoorian and M. Moosazadeh, "Performance Evaluation of Electrocoagulation Process Using Iron-Rod Electrodes for Removing Hardness from Drinking Water," Desalination, Vol. 255, No. 1-3, 2010, pp. 67-71. doi:10.1016/j.desal.2010.01.015

[106] A. A. Bukhari, "Investigation of the Electro-Coagulation Treatment Process for the Removal of Total Suspended Solids and Turbidity from Municipal Wastewater," Bioresource Technology, Vol. 99, No. 5, 2008, pp. 914-921. doi:10.1016/j.biortech.2007.03.015

[107] M. A. Rodrigo, P. Cañizares, C. Buitrón and C. Sáez, "Electrochemical Technologies for the Regeneration of Urban Wastewaters," Electrochimica Acta, Vol. 55, No. 27 2010, pp. 8160-8164. doi:10.1016/j.electacta.2010.01.053

[108] K. Sadeddin, A. Naser and A. Firas, "Removal of Turbidity and Suspended Solids by Electro-Coagulation to Improve Feed Water Quality of Reverse Osmosis Plant," Desalination, Vol. 268, No. 1-3, 2011, pp. 204-207. doi:10.1016/j.desal.2010.10.027

[109] M. G. Kılıç, Ç. Hoşten and Ş. Demirci, “A Parametric Comparative Study of Electrocoagulation and Coagulation Using Ultrafine Quartz Suspensions," Journal of Hazardous Materials, Vol. 171, No. 1-3, 2009, pp. 247252. doi:10.1016/j.jhazmat.2009.05.133

[110] D. Ghernaout, B. Ghernaout and A. Boucherit, "Effect of $\mathrm{pH}$ on Electrocoagulation of Bentonite Suspensions in Batch Using Iron Electrodes," Journal of Dispersion Science and Technology, Vol. 29, No. 9, 2008, pp. 12721275. doi:10.1080/01932690701857483

[111] S. Gao, J. Yang, J. Tian, F. Ma, G. Tu and M. Du, "Electro-Coagulation-Flotation Process for Algae Removal," Journal of Hazardous Materials, Vol. 177, No. 1-3, 2010, pp. 336-343. doi:10.1016/j.jhazmat.2009.12.037

[112] D. Ghernaout, A. Badis, A. Kellil and B. Ghernaout, “Application of Electrocoagulation in Escherichia coli Culture and Two Surface Waters," Desalination, Vol. 219, No. 1-3, 2008, pp. 118-125. doi:10.1016/j.desal.2007.05.010 
[113] C. Ricordel, A. Darchen and D. Hadjiev, "Electrocoagulation-Electroflotation as a Surface Water Treatment for Industrial Uses," Separation and Purification Technology, Vol. 74, No. 3, 2010, pp. 342-347. doi:10.1016/i.seppur.2010.06.024

[114] D. Ghernaout, B. Ghernaout, A. Saiba, A. Boucherit and A. Kellil, "Removal of Humic Acids by Continuous Electromagnetic Treatment Followed by Electrocoagulation in Batch Using Aluminium Electrodes," Desalination, Vol. 239, No. 1-3, 2009, pp. 295-308. doi:10.1016/i.desal.2008.04.001

[115] M. Vepsäläinen, M. Ghiasvand, J. Selin, J. Pienimaa, E. Repo, M. Pulliainen and M. Sillanpää, "Investigations of the Effects of Temperature and Initial Sample $\mathrm{pH}$ on Natural Organic Matter (NOM) Removal with Electrocoagulation Using Response Surface Method (RSM)," Separation and Purification Technology, Vol. 69, No. 3, 2009, pp. 255-261. doi:10.1016/j.seppur.2009.08.001

[116] X. Li, Q. Feng, Q. Meng and Y. Ceng, "Electrocoa- gulation for the Drinking Water Treatment of Polluted Surface Water Supplies," 2nd International Conference on Bioinformatics and Biomedical Engineering, iCBBE 2008, Shanghai, May 2008, pp. 3091-3094.

[117] N. Uduman, V. Bourniquel and M. K. Danquah and A. F. A. Hoadley, "A Parametric Study of Electrocoagulation as a Recovery Process of Marine Microalgae for Biodiesel Production," Chemical Engineering Journal, Vol. 174, No. 1, 2011, pp. 249-257. doi:10.1016/j.cej.2011.09.012

[118] D. Vandamme, S. C. V. Pontes, K. Goiris, I. Foubert, L. J. J. Pinoy and K. Muylaert, "Evaluation of Electro-Coagulation-Flocculation for Harvesting Marine and Freshwater Microalgae," Biotechnology and Bioengineering, Vol. 108, No. 10, 2011, pp. 2320-2329. doi:10.1002/bit.23199

[119] O. Yahiaoui, L. Aizel, H. Lounici, N. Drouiche, M. F. A. Goosen, A. Pauss and N. Mameri, "Evaluating Removal of Metribuzin Pesticide from Contaminated Groundwater Using an Electrochemical Reactor Combined with Ultraviolet Oxidation," Desalination, Vol. 270, No. 1-3, 2011, pp. 84-89. doi:10.1016/j.desal.2010.11.025

[120] A. E. Yilmaz, R. Boncukcuoğlu, M. M. Kocakerim, M. T. Yilmaz and C. Paluluoğlu, "Boron Removal from Geothermal Waters by Electrocoagulation," Journal of Hazardous Materials, Vol. 153, No. 1-2, 2008, pp. 146-151. doi:10.1016/j.jhazmat.2007.08.030

[121] C. P. Nanseu-Njiki, S. R. Tchamango, P. C. Ngom, A. Darchen and E. Ngameni, "Mercury(II) Removal from Water by Electrocoagulation Using Aluminium and Iron Electrodes," Journal of Hazardous Materials, Vol. 168, No. 2-3, 2009, pp. 1430-1436. doi:10.1016/i.jhazmat.2009.03.042

[122] W. Wan, T. J. Pepping, T. Banerji, S. Chaudhari and D. E. Giammar, "Effects of Water Chemistry on Arsenic Removal from Drinking Water by Electrocoagulation," Water Research, Vol. 45, No. 1, 2011, pp. 384-392. doi:10.1016/j.watres.2010.08.016

[123] S. Vasudevan, J. Lakshmi and G. Sozhan, "Studies on the Removal of Iron from Drinking Water by Electrocoa- gulation-A Clean Process," Clean-Soil, Air, Water, Vol.
37, No. 1, 2009, pp. 45-51. doi:10.1002/clen.200800175

[124] D. Ghosh, C. R. Medhi and M. K. Purkait, "Treatment of Drinking Water Containing Iron Using Electrocoagulation," International Journal of Environmental Engineering, Vol. 2, No. 1-3, 2010, pp. 212-227.

[125] S. Vasudevan, S. M. Sheela, J. Lakshmi and G. Sozhan, "Optimization of the Process Parameters for the Removal of Boron from Drinking Water by Electrocoagulation-A Clean Technology," Journal of Chemical Technology and Biotechnology, Vol. 85, No. 7, 2010, pp. 926-933. doi: $10.1002 /$ jctb. 2382

[126] S. Vasudevan, J. Lakshmi and G. Sozhan, "Effects of Alternating and Direct Current in Electrocoagulation Process on the Removal of Cadmium from Water," Journal of Hazardous Materials, Vol. 192, No. 1, 2011, pp. 2634.

[127] E. Keshmirizadeh, S. Yousefi and M. K. Rofouei, "An Investigation on the New Operational Parameter Effective in Cr(VI) Removal Efficiency: A Study on Electrocoagulation by Alternating Pulse Current," Journal of Hazardous Materials, Vol. 190, No. 1-3, 2011, pp. 119-124. doi:10.1016/j.jhazmat.2011.03.010

[128] M. S. Bhatti, D. Kapoor, R. K. Kalia, A. S. Reddy and A. K. Thukral, "RSM and ANN Modeling for Electrocoagulation of Copper from Simulated Wastewater: Multi Objective Optimization Using Genetic Algorithm Approach,” Desalination, Vol. 274, No. 1-3, 2011, pp. 74-80. doi:10.1016/j.desal.2011.01.083

[129] M. Behbahani, M. R. A. Moghaddam and M. Arami, “Techno-Economical Evaluation of Fluoride Removal by Electrocoagulation Process: Optimization through Response Surface Methodology," Desalination, Vol. 271, No. 1-3, 2011, pp. 209-218. doi:10.1016/j.desal.2010.12.033

[130] W. Chou and Y. Huang, "Electrochemical Removal of Indium Ions from Aqueous Solution Using Iron Electrodes," Journal of Hazardous Materials, Vol. 172, No. 1, 2009, pp. 46-53. doi:10.1016/j.jhazmat.2009.06.119

[131] A. Shafaei, M. Rezayee, M. Arami and M. Nikazar, "Removal of $\mathrm{Mn}^{2+}$ Ions from Synthetic Wastewater by Electrocoagulation Process," Desalination, Vol. 260, No. 1-3, 2010, pp. 23-28. doi:10.1016/j.desal.2010.05.006

[132] E. Lacasa, P. Cañizares, C. Sáez, F. J. Fernández and M. A. Rodrigo, "Electrochemical Phosphates Removal Using Iron and Aluminium Electrodes," Chemical Engineering Journal, Vol. 172, No. 1, 2011, pp. 137-143. doi:10.1016/j.cej.2011.05.080

[133] S. Vasudevan, J. Lakshmi, J. Jayaraj and G. Sozhan, "Remediation of Phosphate-Contaminated Water by Electrocoagulation with Aluminium, Aluminium Alloy and Mild Steel Anodes," Journal of Hazardous Materials, Vol. 164, No. 2-3, 2009, pp. 1480-1486. doi:10.1016/j.jhazmat.2008.09.076

[134]Z. V. P. Murthy and S. Parmar, "Removal of Strontium by Electrocoagulation Using Stainless Steel and Aluminum Electrodes," Desalination, Vol. 282, 2011, pp. 63-67. doi:10.1016/j.desal.2011.08.058

[135] G. Moussavi, F. Majidi and M. Farzadkia, "The Influence of Operational Parameters on Elimination of Cyanide from Wastewater Using the Electrocoagulation Process," 
Desalination, Vol. 280, No. 1-3, 2011, pp. 127-133. doi:10.1016/j.desal.2011.06.052

[136] M. Pociecha and D. Lestan, "Using Electrocoagulation for Metal and Chelant Separation from Washing Solution after EDTA Leaching of $\mathrm{Pb}, \mathrm{Zn}$ and Cd Contaminated Soil," Journal of Hazardous Materials, Vol. 174, No. 1-3, 2010, pp. 670-678. doi:10.1016/j.jhazmat.2009.09.103

[137] K. Mansouri, K. Elsaid, A. Bedoui, N. Bensalah and A. Abdel-Wahab, "Application of Electrochemically Dissolved Iron in the Removal of Tannic Acid from Water," Chemical Engineering Journal, Vol. 172, No. 2-3, 2011, pp. 970-976. doi:10.1016/j.cej.2011.07.009
[138] N. Mameri, A. R. Yeddou, H. Lounici, D. Belhocine, H. Grib and B. Bariou, "Defluoridation of Septentrional Sahara Water of North Africa by Electrocoagulation Process Using Bipolar Aluminium Electrodes," Water Research, Vol. 32, No. 5, 1998, pp. 1604-1612. doi:10.1016/S0043-1354(97)00357-6

[139] M. Karhu, V. Kuokkanen, T. Kuokkanen and J. Rämö, "Bench Scale Electrocoagulation Studies of Bio Oil-inWater and Synthetic Oil-in-Water Emulsions," Separation and Purification Technology, Vol. 96, 2012, pp. 296305. doi:10.1016/j.seppur.2012.06.003

\section{Nomenclature}

ANOVA analysis of variance

APC alternating pulse current

BOD biological oxygen demand

$\mathrm{CC}$ conventional coagulation

COD chemical oxygen demand

DTA differential thermal analysis

EC electrocoagulation

EEC electrical energy consumption

EF electro-Fenton process

EM electromagnetic treatment

EMC electrode material consumption

EO electro-oxidation

FTU formazin turbidity unit

HRT hydraulic retention time

NOM natural organic matter

NTU nephelometric turbidity unit

OC operating costs

O \& G oil and grease

PAC poly aluminium chloride

RO reverse osmosis

RSM response surface methodology

TGA thermal gravimetric analysis

TOC total organic carbon

TS total solids

TSS total suspended solids

UV ultraviolet 